

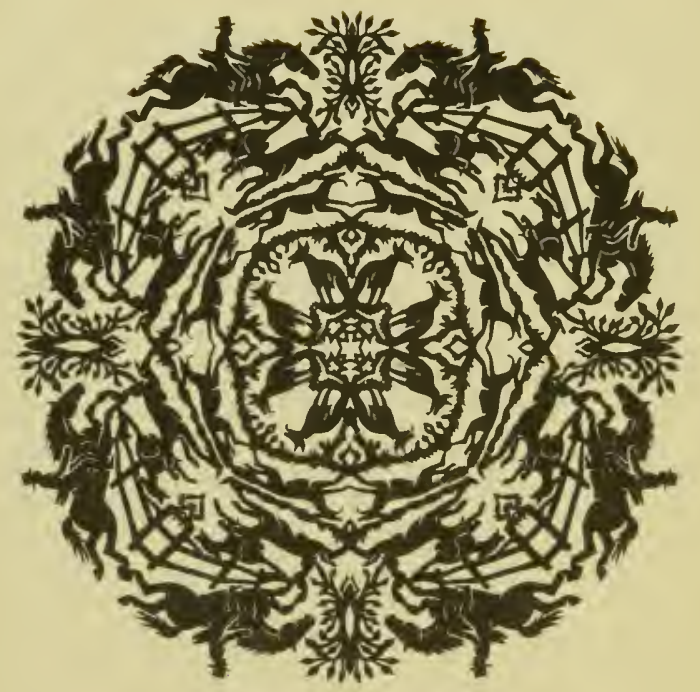

JOHN A.SEAVERNS 





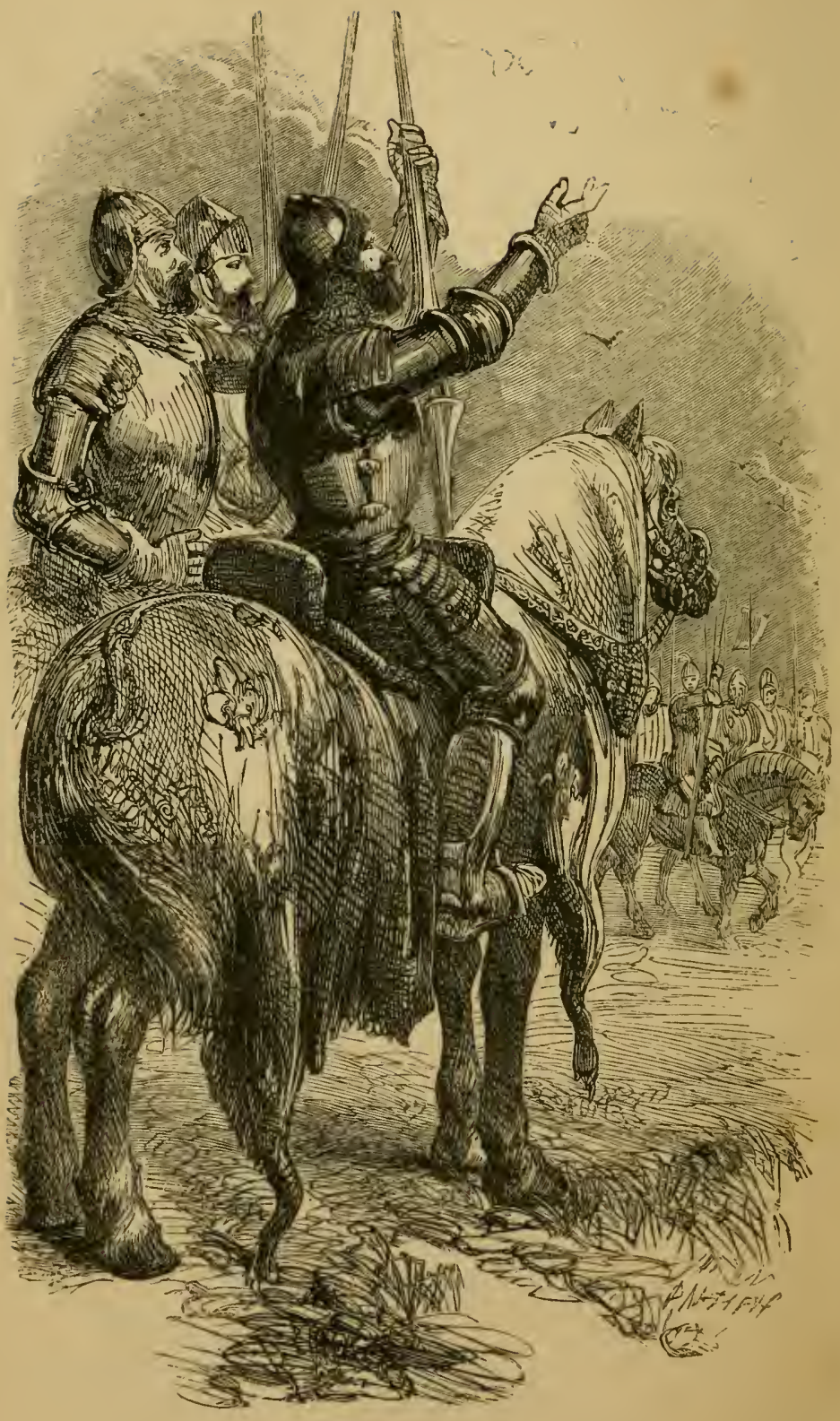

Departure of the English Knights.

P. 168. 


\title{
PRECEPT' AND PRACTICE.
}

\section{BY HARRY HIEOVER,}

\author{
AUTHOR OF \\ "PRUPEB CONDITION OF ALL HORSES," "hINTS TO HORSEMEN," "SPORTING
} FACTS AND BPORTING FANGIRg," \&c. \&c.

\section{LONDON :}

T. C. NEWBY, 30, WELBECK STREET, CAVENDISH SQUARE. 
J. Billing, Printer and Stereotyper, Guildford, Surrey. 


\section{PREF A C E.}

The Proprietors of the "Field" Newspaper, having suggested a desire that I should from time to time furnish a succession of Articles affording such information as might enable those unaccustomed to the possession and management of Horses, to avail themselves of the ordeal I have gone through without its consequent trouble, risk, and expense, I wrote the following sheets. However I may have acquitted myself of so difficult and varied a task, the intentions of the Proprietors of that Journal were, at least, good; and, judging by the approval the articles furnished have met with, I trust my humble efforts have not been made in vain. 
A Journal that now embraces so large a portion of the aristocracy of the kingdom among the subscribers, which are daily increasing, emboldens me to hope that the articles that have stood such test, will meet success with the public when published in the form of a volume, so indexed that any subject may be referred to without trouble. 


\section{PRECEPT AND PRACTICE.}

\section{HINTS TO YOUNG SPORTSMEN AND OTHERS.}

To the very young owner of horses I particularly address myself, well knowing that to be compelled to have their establishment managed for them, however well or satisfactorily it might be done, would do away with half the pleasure they might derive from their newly-acquired possession.

It is very true that a young man educated at home is so accustomed to see the general routine of his father's establishment that he becomes acquainted with even the minutiæ of its arrangement, 
and, on coming into the possession of one of his own, is perfectly qualified for its management. Yet even to him a few hints, aided by long practical experience, would not perhaps be quite thrown away, albeit he might think them not wanted.

Now, the youth brought up at school and college does not possess such advantage. He has only the insight he might gain during the vacations for his guide; and this is not sufficient (whatever he might think) to enable him to manage his horses to the best advantage. But we will go still further, and suppose a youth to have a father who, from pursuits, inclinations, or any other cause, has never kept horses, or perhaps only a pair for his carriage. On his son coming of age, either from the liberality of his father or in his own right, he finds himself in a position to keep his half-dozen hunters or other horses, as his taste or inclinations may lead him. He can know nothing of such matters till practice and experience, at great cost, have taught it him; and it will be found that such experience is not gained in a year or two; but, on the contrary;, when he fancies that years hare 
HINTS TO YOUNG SPORTSMEN AND OTHERS. 3 taught him all he wants to know, he will find he has still much to learn. It is only then that, like a chessplayer when he has attained a certain proficiency, he finds out how little he knows of the game-so, as regards horses, to prevent his being mated at every turn will be the object of these papers.

I have stated in the title "young sportsmen and others." By the term "young," it does not necessarily follow that the man coming into possession of the means of keeping horses must be a youth. The same want of knowledge would exist in the man of fifty unaccustomed to such possessions; and better far for him would it be to know nothing than to just know enough to make him self-sufficient, without knowing enough to do him any good: he would, most probably, from the very little he knows, have formed erroneous opinions, and have come to wrong conclusions, and will as probably persist in them till conviction is forced on him through the medium of his pocket. The great difficulty in getting very young persons to take advice rises from a little natural jealousy of more experienced men underrating their. 
abilities, which idea is a perfectly erroneous one; for we may be fully aware of a younger man possessing far greater ability, talent, and genius, than ourselves, yet, on particular subjects that require practice and experience, we may be perfectly justified in offering advice, which if judiciously given, he will do well to follow, and will probably find time, trouble, and money saved by so doing.

I trust I have, by this short but necessary exordium, shown that I merely bring forward long practical experience in the matters these papers treat on, as sufficient apology for their appearance.

We will suppose an inexperienced young man having acquired the means, and having the inclination to keep a given number of horses; if I knew for what purpose he wanted them, and the favourite pursuit in which he intended using them, it would be easy enough to point out the description of horse adapted to his purpose, the way to treat them when purchased, and-let me say it deferentially-the way to pursue his favourite amusement with the greatest advantage to himself and his horses. But 
HINTS TO IOUNG SPORTSMEN AND OTHERS. 5

this I cannot know; so nothing remains for me to do but to give advice as to the most ready, and in his case the most advantageous way of procuring each sort of horse, the way to treat such horse, and the way to use him-of course leaving it to each individual to make his election as to his pursuit, in the choice of which, though widely different in themselves, provided it is the pursuit of a gentleman, no one has the right to interfere. I may, personally, think fox-hunting the cream of all field-sports; another may think the same of racing; a third may hold his four-in-hand as greater amusement than either; a fourth may, like myself, think the three combined as, figuratively speaking, the summum bonum of all earthly happiness; whereas a fifth may derive no pleasure from either, but hold a ride in Rotten-row during the season, the environs of Brighton at certain periods, and a stroll on horseback in his own park and the surrounding country, the ne plus ultra of equestrian enjoyment-perhaps, so far as this affording him the gratification of ladies' society, which fox-hunting in a general way 
does not, he has the pull in his favour against the fox-hunter; but if the latter has not such advantage for a few hours in the day, perhaps the non-sportsman-what with his club, and peradventure pursuits in which ladies take no part-has not much the advantage in this respect after all. But $I$ have found through life each man upholds his own pursuit as the best; and that pursuit in which he finds the greatest gratification, provided it is harmless, is the best quoad the man. The attempt to ridicule or despise the pursuit of any man, where that pursuit is not despicable, is ridiculous and unworthy. We cannot, if we wished it, reason a man into a taste for fox-hunting, racing, or four-in-hand; we may feel that he loses much pleasure in foregoing all or either of such pursuits; but he has his pleasure in his own way. Let us, therefore, instead of carping at his taste, lend a hand to enable him to enjoy it if it comes within our power to do so.

Thus it will be found these papers are not intended for the racing man, the fox-hunter, the 
HINTS TO YOUNG SPORTSMEN AND OTHER8. 7

driving man, the trotting man, or he who keeps horses merely as the means of affording him healthful recreation; but will, to the best of the writer's ability, afford hints that may be useful to him, let his pursuit be what it may; for whatever it is, to teach him to do it at a proper cost and in a proper way is the great desideratum. The first is comparatively an easy task, though involving a vast deal of circumspection, combination of ideas, and experience in its details; for to this each man will lend a willing ear, satisfied that the writer can have but one object in view, namely, the interest of those for whose information he writes. The latter part of the business is quite a different affair ; for in that there is a certain personal vanity to contend with, which requires very gentle handling. Each man is wonderfully thin-skinned in this particular. Any man, conscious that he knows little or nothing about purchasing a horse, will be quite content to have the best mode pointed out to him; the man quite unaccustomed to stable-practice will be quite willing to be informed in this particular; but he 
is apt, in technical phrase, to "kick" at being told how to use his horse when out of the stablefor there is scarcely a man to be found who has not occasionally driven a gig, or mounted a horse ; and if he has done so, and has not run foul of an omnibus, or if on horseback he has guided his horse home, he does not know enough of the matter to be thankful to Providence that he got home safe -a little bit of truism it would be somewhat difficult to persuade him of, and would require to be couched in most conciliatory terms to render digestible.

It unfortunately happens that in writing on any subject in which the vanity of a man is necessarily attacked by doubting his proficiency in it, he is apt to think that the writer who doubts it really shows a degree of ignorance, or at least bad judgment, in so doing; that what he may say on the subject comes in very questionable shape. It is therefore useless to mince the matter; the writer may just as well, indeed far better, honestly tell such a man that he knows nothing at all about the matter, as to express a doubt about it. But, fortunately, I address no one per- 
HINTS TO YOUNG SPORTSMEN AND OTHERS. 9 sonally. If I point out to those totally unitiated in horse matters the safest line of conduct to pursue, if one so situated fancies he knows a good deal, by all means let him go to work his own way, he will never suppose I allude to $\mathrm{him}$; and if he does know a good deal, of course I do not; though I may, in general terms, allude to many who fancy themselves enjoying such advantage; whereas, in my mind's eye, I bring them into the category of those who know nothing at all, or, at least nothing that can be of the slightest use to them. In speaking slightingly of persons' qualifications or pretensions as regards sporting knowledge, the knowledge of horses or their management, they have no more cause to be offended, or consider that I overstep the bounds of courtesy, than I should have if a man was to tell me I knew nothing of watchmaking. Now, to carry on the metaphor, we will suppose that en amateur, I had amused myself by studying a little of watch-making. I might not be offended at being told I had better not meddle with a repeater or duplex, or a chronometer movement; but if, after talking of ruby palettes, going fusees, 
compensation balances, and so forth, a man was to tell me I had better not attempt to regulate an old vertical watch, with a movement coarse as a roastingjack, it would be a choker-I might, in the exuberance of my wrath, and offended pride in the little I knew of watch-making, draw myself up and ask the man if he thought me a fool. I can, in idea, fancy him very deferentially and respectfully to say, "On the contrary, sir, I know you to be a man of very superior mind and abilities, but this does not teach you watch-making."

Even when we venture a langh (of course a side one) at a man's management of his horses, at the sort he has bought, or at his manner of using them, it is the act we laugh at, quite independent of the man. We laughed at the ludicrous situations in which Grimaldi placed himself; but we did not laugh at the man. He, by his general conduct in life, commanded the respect and esteem of the public and those who knew him. The difference in the two cases is about this. Friend Joe, if he rode his pony or donkey on to the stage, did it in a way to insure our laughter, and he 
was gratified in having caused it. There are those we laugh at also; but our langhter or smile is the last thing they wish to call forth, and they would be as much offended and mortified at having caused it as the other would be pleased and gratified. But in neither case do we laugh at the man, unless in the case of the latter, who might refuse all advice-then his folly or self-sufficiency might fairly justify our risible inclinations.

I always hope to be, and trust I have been so, on good terms with my readers. I never make personal allusions, unless it be in particular cases where honesty impels me to censure the conduct of a clique; and even in so doing, though a particular man may wince from feeling the reprobation come home to him, he cannot say that I have held him up as an object of public obloquy. There are men whose good opinions I am in no way solicitous of possessing, and if asked by one of those if, when speaking of a set, I meant him, I should unhesitatingly reply, "I did, and as one of the very worst of that set:" but I have no apprehension of being attacked by one of 
them. With such men I have nothing to do. But in whatever I may say generally of other men, let me hope that in these sheets, as in my other writings, my assurance will be taken that I allude to no one personally. 


\section{P URCHASING H ORSES.}

WE will suppose a young man come into the possession of such means as may enable him to set up an establishment, be it more or less extensive, and to be quite unaccustomed to the possession of horses of any sort. His first difficulty will be in the purchase of them. We presume that he does not contemplate the making money of them, be they of what kind they may. He may in the first place consider the doing so would be infra dig.; but, as Sandy has it, "wait a wee," he will alter that opinion in time-but we will say that at the present moment the idea of it, under any circumstances, he 
escliews. In fact, he may as well do so as not; for he may rest assured he will not get the chance of doing it. We will, however equally presume that he does not wish to lose heavily by each horse he buys; a result, however, that will be the certain consequence of his purchasing on his own judgment -I should rather say with his want of it-and without advice. Fortunate will it be for him if he possesses a friend qualified for, and willing to undertake, so probably thankless an office as purchasing for him, or, at all events, aiding him by his advice in the selection of his horses. In the first place, in nine cases in ten, the friend, supposing him to be a good judge, will differ materially, if not entirely, in opinion with him as regards the sort of horse fit for the purpose, be it what it may, that the other intends him for. The two will differ, in all probability, as to the looks, action, and even size of the animal to be purchased. The judge will never contemplate the buying anything but a good sort. Here is the first stumbling-block; for we may fairly, and without prejudice, infer that the other does not know what 
a good sort is, and, moreover, will be apt to consider this a matter of far minor importance to that of pleasing his eye and fancy. The judge might in his own case, and probably would, make a little sacrifice of mere beauty to sort; this would be quite at variance with the determination of the youngster. We will suppose that the judge, knowing the sine qua non the other makes of having beauty in his horses, refuses what in his own case he would have purchased on his merits, and determines to find him a good sort, with looks calculated to please the most fas. tidious. He may find one that the most fastidious judge would admire, but it by no means follows that he would please our tyro. He may not come up to his ideas of beauty; and it is equally probable the one that does, may, to the other's genuine taste and judgment, be as useless and complete a brute as ever looked through a bridle. He may have a pretty deer-like head and arched neck, a handsome tail, which he makes the most of, an even level body, not showing an unseemly or prominent bone, with clean legs, yet be such an animal (of which I see many) 
that I should be inclined to use Brummel's exclamation, on seeing his friend in an ill-made coat, "My dear fellow, do you call this thing" a horse? In such a dilemma what is a man to do who wishes conscientiously to discharge his duty to his friend? To sanction in any way his purchasing so useless an inhabitant of a stable is quite out of the question; to declare his abhorrence of the brute, offends. The finale most to be desired would be that it should impress our tyro with so bad an opinion of his friend's taste and judgment, that he declines his interference for the future.

So much for looks; we now come to a more material point-this is action. No horse is worth buying, and still less keeping, who does not possess good action; he will never go comfortably to himself or his master (for he may be to ride or drive), unless he possesses good action; nor will he, in fact, keep in good condition where this is wanting, that is, if used for any purpose for which a fast pace is requisite. Every person must be aware that anything bordering on distress, if constantly repeated, must 
lower condition, and bring a horse to a state below himself, both as regards energy, spirits, and appearance. The horse with bad action is always more or less in distress, if called to perform the same work and pace as the horse with good. What the latter performs with ease, is labour to the former; and what is merely a little extra exertion to the horse with good action, becomes distress to the one with bad. Now, if the young gentleman follows his own judgment, he will probably in some way or other fall into error, as an acquaintance of mine did.

We had a mutual friend, who walked an honest fifteen stone five, and stood six feet two. He, of course, rode very powerful horses, and, by good judgment, being a particularly bold and fine horseman, always rode in the first flight. The acquaintance I speak of, rode about ten stone, and was about five feet three. Seeing the way in which our friend of welter weight went, he got it in his head that monster hunters were alone worth buying; but, being rather a timid rider, and not possessing the best judgment, he soon found such horses could not afford to make 
the circuit of a field to avoid a fence that was not to the taste of their master-that is, they could lay with hounds, if ridden straight, but could not catch them. In fact, he was nowhere with them, riding as he did. He got rid of them, and then got three weeds of thorough-bred ones; giving us his new-formed opinion, that "pace was nothing to thorough-breds" - "an ounce of blood was worth a pound of bone" - "blood is the ticket, after all." He even assumed the style of riding of the jockey; and had the Racing Calendar by him, to show where his horses had won a race against some wretches more worthless than themselves, and been constantly beaten by fourth or fifth-rate animals. Our hero was not aware that they were so; so thought his horses ran well, though they did not win. "Hunter's pace," he would say, "is nothing to a racehorse." He was so far right; it does not call often upon the full speed of the racehorse, though a moderate one ; but there must be some strength to cope with the difference of a four-mile burst across country and a mile spurt over a race-course, with perhaps ten 
stone to carry. - We cannot exactly say what Somerville does of very undersized hounds :

\section{The puny breed in every furrow swims;}

but the spirit of the allusion holds good as regards weeds as hunters. Our little friend did not find. that "blood was the ticket" when labouring over a ploughed field pastern deep, or, what is more holding still, a pasture in a soft state. He also found that even in a light country his thorough-breds were not more efficient; for there were fences to be taken, and no one had thought it worth his time to teach fencing to horses--or rather wretches-that no man but our friend would have contemplated making hunters of, or rather attempting to do so. It ended, after having tried each sort for two seasons, and finding neither the right one-in his getting his welter friend to purchase three for him. He then got horses that could carry him. From the way they did this, he got confidence, rode more boldly, and had gained something like judgment. Still his friend always beat him across country; but let me say, 
in excuse for the light weight, the one had had twenty years' experience, the other was in his novitiate.

I have mentioned the foregoing anecdote, first, to show that an injudicious selection as to the sort for the use they are intended for will always be attended with the finding that duty badly performed, to the disappointment of the owner; secondly, to show that nothing short of having conviction forced upon them will convince most persons of the fact. It will be found just the same as respects action.

The goodness of action, of course, depends on the purpose for which the horse is intended. As regards road-horses, whether in harness or out of it, there is fashionable action, which is by no means always indicative of good action, and good action that is not fashionable action-at least, does not come up to the present taste. This does not hold good as regards hunters or racehorses. Those must possess a style of going that fits them to perform the purposes for which they are used to the best advantage; the hunter must go in a form that enables him to combine speed with lasting qualities. It is true, it mat- 
ters little how the racehorse goes in his slow paces; but he must go well in his fast ones; in fact, though we cannot exactly detect his action when at speed, it is quite certain it is such as enables hin to go fast, so it is good action for him. With the hunter we must not indulge in fancy as regards his action; he has arduous duties to perform, and must go really well. If we permitted our fancies to guide us as respects his action, he might be admired by the mere tyros at the meet, but, like many of those, would not be seen after the first ten minutes. We cannot afford to be guided by fancy as to the action of the racehorse ; for winning or losing the Two Thousand would be rather an expensive price to pay for fashion or fancy.

But we will suppose our young purchaser of horses has a fancy as to action in his horses; and so far as road horses are concerned, the consequence of that fancy being good or bad will amount to this-he will in the first case have his work well done by them, they will be admired, and if he chooses to dispose of one or more of them he will get a fair price for 
them, though probably not what he gave. In the other case, he will have little or no satisfaction from his horses while in lis possession; no one will admire them (unless he is fortunate enough to find one as little of a judge as himself); and he will find that somehow they have diminished in value about two-thirds as regards price, since he purchased them.

The kind of action we suppose the young purchaser to fix on as his idea of perfection, or something like it, will depend greatly on his own habits, and on the class of men he chooses to model himself by; but I fear he will find that, whichever he chooses, he will not gain much credit with them as regards his taste in horses. We will suppose that from some cause the memory of Lord George Bentinck has taken possession of his idea; he certainly could not choose a better model than that nobleman if he were to follow his example in the many commendable things he did for the benefit of the turf. This he does not know how to do, nor has he, or ever will he, have the means of doing so. He will 
probably do what he considers it likely Lord George did, or any celebrated character on the turf might do, and buys his horses for any purpose he designs them, of a racing sort-forgetting that men who keep a string of race-horses are no more inclined to have one of the sort for their private use than other men, probably not as much so. But our youngster has got it in his head that it is stylish to be seen on a thoroughbred, so purchases liorses of this sort, who go kicking the stones about (if luckily those stones are moveable), and creating a sensation (to be felt, but not described) to the rider when they are not-he, peradventure, affecting a style of kicking such animal along, contracted from habit by the exercise-lads of a racing stable. We hardly know which is the most to be ridiculed-the selection of the horse, or the assumed manner of riding him.

Our tyro may, on another tack, fancy a military character the one he should like to assume. In such case he gets his horses with charger-like action : and having seen such horses, at proper times and on proper occasions, create surprise, and indeed admi- 
ration, by their evolutions, he sits in military style, and annoys bystanders and passers-by, by causing his horse to bespatter all near him by throwing the mud in their faces by his forced and absurd curvetings.

These are two absurdities we have seen in equestrians; but perhaps our tyro avoids both, and patronises a cabriolet. He sees and hears that high action is the rage, so, provided the action be high, he considers he has got what all must admire. He is not aware there is a vast difference in the style of such action, so it will not be improbable but he gets a brute with similar action to those greatest of all possible beasts that we daily see in hearses and mourning-coaches-the only duty for which they are fit. Their action is as heavy as any of the horses we daily see in Pickford's vans, without any of the good qualities to be found in them. Now a horse with high and grand action should go as if he stepped on india-rubber. We should, figuratively speaking, be unable to detect his foot on the ground; whereas the other brute brings lis great platter feet down 
like the beater with which gardeners level newlylaid turf.

Unusually high action is not favourable to speed, yet there are some horses very fast, notwithstanding; but then their step is quick and light, and not that of-if I may adopt a word for the occasion-the pounding step of a bad sort of Hanoverian, who, being of no real use to any living man, are very properly kept for the only duty they are fit for, and that a sad one. 


\section{PURCHASING HORSES AND ITS CONSEQUENCES.}

\section{(Continued.)}

We will suppose our young purchaser to have made his purchases; and, concluding that he uses horses both for riding and driving, premise that he has bought for each purpose what he considers stylish and to his taste, whether he assumes the military or racing man in his sort of horse and his manner of riding it, and his D'Orsay style of driving when the cabriolet is called forth. For some time he is content-nay, gratified; for, creating surprise, he is quite satisfied that he calls forth admiration as regards both himself and his horses. But somehow or other, after a time he gets somewhat sceptical on 
this point; for probahly "some $d-d$ good-natured friend" has enlightened him on the point, and to his dismay he finds his horses have not been admired. He has for some time found they did not do their business like those of many others he has seen; and, "horror upon horrors!" he has had more than one unequivocal hint that his manner of using them was not in the best taste. If he assumes the racing style, racing men, trainers, jockeys, head-lads, down to the exercise-boys, smile when they get a chance look at him. The first four think they should much like to make a bet with him on any event; the latter say to each other, "Don't he think he could win the Darby?" If he had adopted the military style, the result would be about this :-Military men, from the colonel to the cornet, good-naturedly smiled, and thought that, as he had a military taste, and moreover the still greater recommendation to a cavalry regiment, money, it was a pity he should play the pseudosoldier while a commission was to be got. The less well disposed $d-d$ him for a fool; while the subordinates, on seeing his military seat, hailed him with 
"threes to the right," or some other derisive expression.

Some, on seeing the kind of nag he drove, were inclined to set him down as some German baron or chevalier d'industrie, or both combined; but reflecting that foreigners nowadays know good horses when they see them, and possess themselves of really fine animals, they came to the conclusion that he was the hopeful son of some undertaker. And they saw he was an undertaker of what he had not the judgment or taste to do properly-a fact of which he had at length become convinced himself.

This could not, or, at all events, he determined it should not, go on; to spend his money, and, instead of exciting admiration, getting nothing but ridicule for his outlay, was not to be borne. True, he had created a sensation; and as Bolingbroke, when he made his appearance, "like a comet, he was wondered at." But unlike him, he was not gratified by hearing people inquire-" Which, which is Bolingbroke?" He had heard some military men say to any who did not know him, "Oh, it's young 'Alex- 
ander !"' Supposing he had adopted the racing style, he would probably hear he had got the sobriquet of "Young Buckle" for his pains.

Whichever way his taste may have tended, at all events it tended to no credit to himself, and he determines to make an alteration. "Facile descensus Averni" -he had found this easy enough ; "sed re. vocare gradus" - of this he was to find the difficulty. In the first place, he must sell-or, in his case, get rid is a more appropriate expression-of his horses. Now, we all know that as regards the generality of men, the selling anything they possess, is an act usually attended with considerable loss, whether it be a horse, a carriage, a gun, dawn to a French moderator-lamp-even supposing each to be good of its kind, and to have been bought at a fair price. When we purchased either, we wanted them. The difficulty in selling is to find a person who wants what we wish to part with : if we sell to a dealer, he has to find this, and consequently will not buy, except at a price that they will command at any moment convenience or necessity may induce him to 
sell. Such is the usual result of buying and selling where persons buy with moderate judgment, as to quality and price. With a thorough judge it is quite different. What he buys is always wanted by somebody; all he has to do is to make it known that what he has is to be parted with. This is a case we are not treating on at present; so we pass it by with the few words we have written.

Now our young purchaser is the very antithesis of the last-named character, and a very poor representative, indeed, of the first. He has bought badly. He will find no one willing to reimburse him for this. He has bought what is bad of its kind, and nothing, while in his possession, was done to improve it, or even set it off to the best advantage under such circumstances. I think I did not calculate an exaggerated Joss when I stated in Hint II. that about two-thirds would be the diminution in price : not that the property had probably diminished in value, but he had, at the time of purchase, bought what nobody would look at but himself; and he will find, when wanting to sell, their taste and judgment unaltered. : 
I am quite aware that I may be accused of supposing an extreme case, as regards the young gentleman commencing his career as keeping an establishment. It may be said, Why should a young man of common sense assume a military or racing prestige? Why should he get a horse for his cabriolet that subjected him to being taken for an undertaker? I will endeavour to answer such observation. First as regards his sense: there are very few young men who have sense enough to prefer the being thought sensible to the being held fashionable; there are few who would hold the mere being thought gentlemanly anything bordering on an equivalent to the being held dashing fellows. Notoriety is their watchword, and this they will seek at the expense of sense, even if they know it to be so. But our hero did not know this. He thought that in assuming a particular style, he was doing something out of the common way - a something few did-and, we will suppose, exclaimed with Norval, "Dear or alive, let me but be renowned!"

It may be asked, Why not suppose him to have 
assumed the character of the hunting man? A season or two hence he will probably attempt this. But in his early career he had not seen hunting men where they are unmistakeably such-that is, at the cover-side. He had probably seen hundreds in their ordinary costume and bearing as gentlemen. But he would have said, had any conspicuous character been pointed out to him, "What! is that gentleman in the plain black frock and grey trousers, riding the little brown horse, Lord — $\longrightarrow$ Sir — that I have heard of as a leading man with the Quorn?" Doubtless, he expected to see some indications of his celebrity in the field brought forward in Rotten Row. He had no idea that any man could forego, much less avoid, the being ostensible. Thus I hope I have accounted for the conduct of some very young and very inexperienced ones making themselves ridiculous, without meaning it as any impeachment on their good sense in other particulars.

Our hero was now in a rather unpleasant dilemma. To drop at once his military or racing assumptions of style, whatever it may have been, required some 
tact not to have it seen; he had found himself laughed at. It is unpleasant to have the conviction forced on us that we have played a very foolish part; to have others see it also makes one wince again; but to be subject to the jokes of one's friends on such circumstance is flaying us alive. However, our young purchaser heroically resolves to bear this, wisely considering it better to be laughed at for what we have done, than to persevere in a bad cause, and be laughed at for that. But he is in another dilemma as regards the getting rid of his stud, such as it is. The advertising them as his property, to be sold at Tattersall's, would probably call forth remarks on them and him not the most pleasant or flattering. To offer them to his friends and acquaintances, various hints that had been thrown out as regarded their opinion of them convinced him would be worse than useless. To offer them to a dealer would be virtually like giving a man one to take away the other five. He would offer them to a dealer in exchange, butthen he must again trust to his own judgment in selecting the horses he was to exchange them. 
for ; and this he had at last wisely resolved not to do. At last he prudently determined to do that which, had he done in the commencement of his career, would have saved himself much expense, much disappointment, no small share of ridicule, and subsequent mortification, from the feeling it had been called forth with reason. He consulted a friend, one who was a perfect judge of such matters, and one who goodnaturedly was quite willing to give the young purchaser the benefit of experience and sound judgment.

I here find, though the "Hints to Young Sportsmen" are intended to be at the service of any to whom they may be of use, it will be as well candidly to admit that the supposed case of the young purchaser, though not altogether a real one, is so near what I have seen in many instances, that it is like a paletot or a poncho-would fit many, but has nothing about it to lead to the certainty of its being made for any particular individual.

Our hero, having gained the promise of assistance from his friend, asked his opinion respecting sending his stud to be sold at the Corner. I can fancy a 
most wicked, though by no means ill-natured smile, to curl the lip of the friend at the term "stud" being used; yet, courteously making no remark on the inappropriateness of the term, he simply threw out a hint that "Mr. Tattersall having usually, at that particular time of year, some extensive and valuable studs on hand, he would recommend that of our hero being sent forthwith to Dixon's, where they would meet every attention, and probably attract the notice of some of the young East-enders who wished to be well mounted." At the words "well mounted," he gave a peculiar kind of gulp, as we do if we get hold of an oyster, the flavour of which is equivocal. Our hero gave a particular look towards his adviser, indicative of a suspicion of his real motives in giving this advice, and at the same time an unwillingness to have those suspicions confirmed. It was lucky that he did so, for his friend was quite the man to have said at once, if pushed to extremity, "Send the brutes where you are certain they will be sold at once; and I will give you, unasked, another bit of advice-having got rid of the horses, get rid of the 
grooms (as they call themselves) who have had the charge of them: we will then see if we cannot get you a better sort of horse and man."

Here was a pretty finale. His six horses had cost him a sum averaging above a hundred a horse; inexperienced as he was, he quite knew such prices were unknown at Dixon's; and from his friend's hints he felt equally aware that in the case of his stud they would be equally unknown, or rather unbid, at Tattersall's. It is very true that " he is to be sold," or " my instructions are to sell him," at once create attention at this place, the public well knowing that this assertion is never made here as a fetch-for, though stating the very reverse of fact has been long held the privilege of auctioneers, to the credit of this establishment it is not held so here-but still "he is to be sold," of course, means if any one is willing to huy him, and the gentlemen accustomed to attend Tattersall's will not buy unless they see what they like; and that his horses should be at the mercy of the few low dealers to be found there who will not oppose each other, was not the wish of the owner of 
the "stud:" so he determined to send them where they were good enough (bad as they were) to attract the attention of some of the company. So to Dixon's they went, and there also went the two friends incog.

Now, our leading counsel had advised his client not to send his grooms with the horses, that is, not to wait with them-alleging as his motive for doing so, that people might infer that the assurance that they were to be sold without reserve was a catch, and that the servants waited to take back those unsold. This appeared plausible enough, but his motives for this advice were these : he felt perfectly satisfied, or rather convinced, that either of his friend's servants were of a kind to be quite willing, for a half-crown put into their hand, to "sell" their master; but as this would not tend to sell the horses, he advised their not having the chance given them. However, he had another reason for advising the horses not being made a fuss with as a "stud." He.knew that any judge would in such case say, "Who on earth could have collected such a set of wretches and call them 'a stud?'" 


\section{PURCHASING HORSES THE RIGHT WAY.}

Is Hint II. I gave some insight into the motives of the friend giving the advice he did as to the most eligible way of getting rid of the young gentleman's horses. "Getting rid of" appears a most disrespectful way of alluding to a stud, I admit; but, having given in a general way some idea of the animals that composed that stud, others of a different caste need not snort at the expression, for far be it from me to apply it to them. Having thus made the umencle honorable to studs in general, who usually are sold in far different localities to that chosen for the present occasion, we will just take a look in at Dixon's. I have said the friends had determined to 
do this incog., well knowing their interference could do no good, and feeling convinced the owner of the establishment would get the best price he could induce persons to give, usually accustomed to bid for machiners, omnibus horses, and animals of that ilk.

Though the person of the owner of the horses was quite unknown in the yard, some hint had been given to the stablemen; for, on our hero making his appearance, the head man, touching his hat, opened the ball by saying,

"Nice horses, yours, Sir; we don't often get a stud on sale here."

Our hero rather liked this, and rather liked the head man, or rather foreman, thought him a civil fellow, and also thought that he thought favourably of the horses-so slipped five shillings into his hand as earnest of what he might expect if the horses sold well.

The friend smiled at all this, and the meaning of that smile may be expressed by one word- "gammon:" not that he thought the five shillings misap- 
plied, knowing as he did that it was in the power of the men to injure the sale of the horses a good deal, though they could do little or nothing in furtherance of it; but, if he did not think the five shillings misapplied, he knew the assurance of their being "nice horses" was, and the foreman knew so too, which accounts for the smile of our friend, with its plebeian meaning.

The morning of sale, namely the next day, came, the horses were brought out at an hour most favourable to them. The auctioneer did them all the justice in his power; and though he indulged in terms unusual at the West End, and at variance with those the sporting world are accustomed to hear, as the sporting world were not there, and would not purchase these horses had they been so, it mattered little.

Got rid of they were- "given away," as their master thought_ "d-d well sold," as the friend said. "Three hundred pounds," thought our hero to himself, "for what cost me eight or thereabouts !"

But even that sacrifice was not the extent of the 
erent, for there came-two nights' livery, at $3 s$. $6 d$, $2 l .2 s_{*}$; six halters, $6 s$.; commission on $300 l ., 15 l$; leaving a balance of $283 l$. 12s. Then came the men touching their hats (that is those who used one, and those who did not pulled their foretops, which spoke the same language). Our hero had sense enough to do the needful with a good grace (though very few do)-why should he not? The nags had fetched as much as they were worth; no one ought to suffer from the folly-or rather want of knowledge-of the purchaser but himself; but he bad got a lesson in horse affairs it was not likely he would soon forget.

But, be it remembered, this lesson only served him so far as the rudiments of the very complex science of buying went: he had seen the effects of buying without judgment; but this, though something gained, went but little way tọwards teaching him to buy judiciously. Having, however, got rid of the stud, for the present his expense as regarded them had ceased; and having wisely taken his friend's advice as to his grooms, the expense of 
them, which had been no trifling affair, ceased also. So we will leave him for a time, and consider the different modes of purchasing horses.

The usual way for persons to buy horses is naturally enough to go to a dealer, as we go to a dealer in any other commodity of which we stand in need; and to many persons it is the readiest way. But the practised judge goes a different way to work; in a general way, he is a bad customer to dealers, not from the idea that very erroneously deters many persons from doing so-namely, the fear of being, in common parlance, "taken in :" in the first place, he knows too much for that; in the second, he very properly considers a respectable dealer in horses as honest a man as a dealer in wine-and, in truth, there is quite as much opportunity for deception in the one trade as in the other-and, from the experience I have had, I should say the deception used in the latter trade is fully equal to any occasionally practised in the former.

It is held a heinous crime in the breeder to knock out a couple of teeth to promote the earlier appear- 
ance of others, consequently (unless to very experienced judges) giving the colt the appearance of being a year older than his true age. It would be held equally flagitious for a dealer to file and clean a horse's teeth, to cause deception as to his age. But how many bottles of port-wine are daily drank (where men are not connoisseurs) that have been made of proper age by tartaric acid, with orris-root and elder-flowers to create a tempting bouquet, and brandy to give strength; while the term "sweating in," pretty well known to the dealers in wine, prevents its addition being detected.

An artificial crust is easily made, and the colouring of the cork promotes the deception: But best of all is the stale trick of exhibiting wine with the bottles so covered with dirt and cobwebs, that had the wine lain in the cellar from the days of our grandfathers it could never have collected round it. Talk of horsedealers, they are, in point of deception, paragons of virtue, mere bunglers in their business, to some expert wine-merchants.

The reason the practised judge does not usually 
go to the dealer is, he usually goes on the same tack as themselves-buys the raw material, brings it to a state in which it is fit for any person's use, and then, if a man of large means, keeps it for his own, or, if money is an object, sells it to those who do not know enough, or are indisposed to do what he has done.

Notwithstanding my saying what I have, I have, personally, frequently bought horses of dealers; but it has been in this way-a dealer sometimes gets hold of a horse that disappoints his hopes; he has no fault bad enough to return him to the person from whom he was purchased, and yet the failing is such as to be fatal to his sale to the generality of persons.

This he might not have exhibited at the time he was bought, and perhaps the seller was as little aware of his having it as the purchaser. For instance, he may have, in technical terms, "a little will of his own"-perhaps nothing more than a little hesitation at times in obeying the wish of the rider. This, if shown, would deter nine men in ten from buying him. They would suspect its being restive; 
and, not knowing the horse, would not know to what extent he might carry it. The assurance of the dealer that he was not so, would not be believed; the customer declines him; so that he might as well, as regards his sale, really be the most restive brute in existence.

Again, some horses will at times kick a little on being first mounted. One customer, on finding this, would not have him at any price; another would not have the brute as a gift. He is returned to the stable.

Another is quite quiet to mount, and ready to go any way wished, but is a littie shy of carriages, perhaps; and probably in the country, from which he had re. cently been brought, he was totally unaccustomed to meet, or see them. This, time and a little patience would remedy; but it is not worth the dealer's while to wait that time, and he will not persuade his customers that it is worth theirs, still less will they exercise the requisite patience-he is "shelved."

These with many others are failings fatal to the horse while in the dealer's bands, and he has not the 
time, opportunity, or persons to spare to remedy the defect; he resolves to "ship him," in plain terms sell him. We will say the horse was bought, and well boright, at eighty - that is, had he not the trifling and probably temporary failing he has. Now, there is an honourable feeling in breeders, from whom dealers buy most of their horses, that is highly creditable to them. If a horse they have sold turns out to have some fault or failing unknown at the time of sale, that is not of a nature to authorise his being returned, if it is one that prevents his sale, and the dealer in consequence loses money by him, on a proper representation and proof of the fact being made, they usually throw back something of the original purchase money. Thus, if the dealer gave eighty, the seller throws back five or ten pounds; this, of course, only taking place between men accustomed to dealings with each other. In such case, I have often offered (say) $65 l$. for the horse, "take him as he is." I have found it take me a month or two, perhaps a year, to properly cure him of his objectionable qualities; but, being cured, I have a right to $120 l$., for keep, and the exercise of risk, time, and patience, 
when he has become a perfect and amenable hunter. Such have been my principal dealings with dealers.

But these dealings have in some instances gone far beyond. It often happens that a dealer, to oblige his customer, and, we will say, to consult his own interest at the same time, takes a horse of a gentleman in exchange. Now any deception on the part of gentlemen one to another is, and is held to be, unworthy their character; but towards a dealer it is otherwise. The gentleman admits his horse has a little will of his own; the dealer, relying on the representation made, takes the horse, but finds on trial he is a confirmed reprobate. Here is a case in which I have bought horses from dealers-to use a technical term, "at a price;" but it in no shape follows that I would recommend others to do so. Comparatively small means and expensive ideas often go hand-in-hand, but find it difficult to get on to their mutual satisfaction. My pride determined me to ride as fine horses as any man could have; but never having been a man of large means, I bought merely good looks, and generally found a somewhat unusual 
command of temper and patience, with a fair share of nerve, brought out qualifications; and then-why then somebody paid for the exercise of them. It is all very well for a man with twenty thousand a year to go to a first-rate hunting dealer and give him three hundred for a made hunter; or he may go to Tattersall's, have his pick of a stud, and give a still higher price. I should, if his circumstances admitted of it, perhaps recommend a friend to do one or the other; or he might do what some persons are most anxious to do-treat with the owner personally, but which would probably end something in this manner.

A few seasons back, a stud of twelve were sent to Tattersall's to be sold: they were all masters of great weight; belonged to one who always rode in the first flight ; and were, moreover, remarkably well-selected, fine horses. A gentleman got the ear of the owner, and asked if he was disposed to sell a particular horse before he was brought to the hammer. "I mean to sell them all," said the owner, "and I know there are purchasers for every one of them. But what horse do you wish to buy?" "The grey." 
"If," replied the owner, "I part him from the rest, his price is a thousand." Had the whole of Tattersall's premises - stud, carriages, and company-been annihilated, it would not more have astonished the gentleman than the price named. So much for, as people term it, "getting at the owner."

Now in my own experience I have generally found this "getting at the owner," by which people seem to think they are certain to "get at the truth," to be about the worst thing any man can do: and I shall somewhat surprise my readers in saying, "particularly if that owner happens to be a gentleman." In the first place, we should bear in mind that it is more to the interest of the owner than to any one to deceive us (if disposed to do so) as to the value and qualifications of his horses. But why I consider any application to or conference with him, supposing him to be a gentleman, to be useless, is, that he has been so accustomed to hear his horses praised, and to have his ideas of their value raised to fabulous prices, that, until he has ascertained their real worth by what persons are disposed to bid for them at the 
lammer, he deceives himself in this particular; consequently there is seldom much chance of dealing with him.

Horses not known at Tattersall's are very often sold far beneath their real value, their qualifications being unknown; but when a stud is sent there, persons who know them, and have seen their performance, are sure to be there to purchase if they can, and what is then offered is their real worth. 


\section{PURCHASING HORSES,}

(Continued.)

WE have seen, or at all events $I$ have endeavoured to show, that "getting at" the owner of horses is not so sure a way of getting at the truth as some people imagine. I will now state what I have done myself when buying at Tattersall's, by which I usually got what information I wanted.

If you are thought well of by the head man of the yard (which I should strongly recommend every one to be who is in the habit of purchasing horses at the hammer), he will cheerfully give you every information consistent with the duty he owes his employers. To apply to any one else is worse than 
useless; the clerk in the office knows nothing of the horses, unless it be to whom they belong, and not always that-he knows only the name they are booked in.

Applying to the men hired for the day as strappers, is only paying for information of a very doubtful character. It is all very well to give a man a shilling if you have seen a horse or two out: it is expected; and you will be a marked man among those gentry if you do not. We will suppose a horse has been out, and found to be lame, or a roarer; if you, not knowing this, are struck with his appearance in the stable, and are known and respected by these men, they will give you a hint of the failings he has shown; if, on the contrary, you are known as a mean man, depend on it they will help you to a bargain (if they can). I here allude to horses left for sale, without a private servant to attend them.

When a stud is sent for sale, if fortunately you happen to have a friend who has hunted in the country the horses came from, he will give you a correct account of the qualifications of each horse, 
and the estimation in which he was held in the hunt he belonged to. Now, what jou are likely to be able to buy must depend on the length of your purse; if that is unlimited, your friend will very properly point out to you the most perfect horses among them; and in such case you will get a perfect hunter-that is, perfect for a country like the one he came from, probably all but perfect in any-but then be prepared with your two or three hundred, or sometimes more, supposing the horse to be as faultless as a hunter can be.

But, supposing you limit yourself to (say) a hundred, and your friend knows that, he may point out a far better-looking horse-one who can do all the other can-nay, more, he may know him to be the fastest horse of the two, the wider and higher jumper ; but then he is perhaps a little impatient at first, pulls a little stronger than very fastidious men like, may be apt to get his head a little up. Your friend may, as I say, point out such a horse, and add, "I dare say you will get him at about your price." The question, therefore, merges into this-Are you con- 
tent to get as good a hunter as a man can ride, with a very trifling failing, for a hundred, or do you choose to pay a couple of hundred extra where such failing does not exist?

You may fancy that you can cure him of any bad propensity he may have. If you are a very fine horseman, with fine hands, great nerve, patience, and command of temper, you certainly can cure, or at least greatly lessen, any fault a horse under ordinary circumstances may possess; but do not flatter yourself there is anything like a certainty of your doing so in this case. A horse of such pretensions as we state the supposed one to possess-a horse that but for a something, would be worth as much as any hunter living - depend upon it, has had the best of horsemen on his back, and the utmost they could do with him has been done. If you buy him, you must be content with him as he is; and, after all, his failings may only call for a little trouble and patience on the part of the rider.

But among men of large fortunes there are many who will say, "I will be carried in the front rank, 
and I will at the same time have a horse that gives me no trouble."

Such a man has an unquestionable right to have what he wishes; he pays dearly for it; it is a luxury, a refinement on luxury: perhaps we night say there are plenty of ways in which the extra two hundred he pays for it might be better disposed of, but we might say the same of every thing in which the man of wealth chooses to indulge himself at great cost; it is well for sellers that he does so; for if he did not spend the extra two hundred in this way, he would in some other case of self-indulgence.

But let us return to the subject of Tattersall's, and suppose a man has not a friend who knows the stud sent for sale; the mode I have used in my own proceedings has been this :-

Having ascertained to whom the horses belong, and the country they have been accustomed to go over, I give a shrewd guess at the chief qualifications of horses accustomed to that kind of country. For instance, if I found they had been accustomed to a light-riding country, with light fences, I should be 
sure that, take them as a stud, they would make no figure in a hervy-holding one, with strong fences to encounter-in fact, we may be pretty sure that, take them as a number of horses, they would not be the sort; and vice versâ, if coming from a heavy country, they would not, as a whole, be suited to a flying one.

Here judgment, reflection, and tact come in. I get hold of the head-groom in charge of the horses (having first taken care that the head groom at Tattersall's has apprised the other that I am not oneto ask a number of questions), get the information I want, and also get a horse that is likely to suit me, and think this well paid for by half-a-crown. Possibly the one groom, in speaking of me to the other, may do so in terms something like these :

"He is a friend of mine, a dev'lish good fellow. I knew him when I was hunting-groom to Lord ?."

Pretty familiar, many would say; but reflection will convince the very thin-skinned that no impertinence is meant. The one groom would know that 
being called " a friend of mine," only meant to say, "many a half-crown I have had of his," and the being "a dev'lish good fellow" meant I had always paid my own servants well, and those of other persons liberally, when they did any thing to serve or oblige me. Better be spoken of so, than as I heard a nobleman remarked on in the same place:

"Yes, my Lord," said the man, touching his hat; and when gone, "A pretty devil you are for a lord -a shilling !" looking contemptuously at the coin in his hand.

Now, as respects my getting the information I want, it will be seen I seek none from the servants of the establishment that the owner of it would object to, and no one would repudiate more than myself the bribing the servant of any man to betray the interests of his master; it will be seen $I$ do nothing: of the kind.

A nobleman or gentleman sends (say) ten hunters to be sold; I wish to purchase one. As they will all be sold, it is quite immaterial to the owner who purchases each particular horse; it is as immaterial 
to the groom-in fact, he would act in accordance with the wishes of his master, could he be the means of each man's purchasing the horse likely to answer his purpose.

I have always found that in every stud there are one, two, or three horses, that have somehow got there, but never suited the country, consequently were little thought of. Those who did suit it, and were first-rate there, I should know would fetch almost fabulous prices from some one. With such I, as a purchaser, could have nothing to do; my object would be to find out the one or two who did not, and for this purpose I should apply to the groom, who had probably ridden all of them, and knew their different qualities.

- Now there are many persons who, in applying to a groom for such information as they want, will put a number of questions to him, promising, in order to make him communicative, that, if they get what they want, they "will remember him," or what is tantamount, they "will not forget him." No man but a fool will give himself the trouble of answering 
questions on such very equirocal assurance, unless he knows the inquiring party well.

We will suppose I do not know the stud-groom, and what he knows of me has been from the head man of the yard. I introduce myself by slipping five shillings into his hand. This induces him to pay attention to my assurance that, if I get a horse that suits my purpose, a sovereign or a couple will be forthcoming. Here a hint from one who knows well how the thing works may be useful. It is always a bad plan to promise that you will, as I have stated, "not forget a man" if be does a certain thing. In the first place, promises of what you will do, unless you are well known, avail nothing, and your ideas and those of the man to whom you make the promise are very apt to differ as regards the value of the consideration. The old adage of "a bird in hand being worth two in the bush" is held in full force on these occasions. The five shillings must be given on the chance of whether you buy or not; and depend on it, "it tells" in some way or other.

The mode of your inquiry will show the groom 
whether you really intend to buy if you can; the five shillings risked convinces him that you are in earnest, and the questions you ask will further satisfy him not only that such is the case, but that you know what you are talking about and what you wantgrooms, as well as others, often find persons who know neither.

I shall, perhaps, surprise my readers when I say that it is not always advisable to buy horses that have been accustomed to a country similar to the one you intend taking the horse to that you intend to buy; I say not always, for its being so or not depends on who the person may be, intending to buy. If a man to whom price is no object, I should say by all means buy a horse who has gone over, and gone over well, the lind of country you intend to hunt him in ; if price is an object, endeavour to find some horse among the stud who had no business there, one whose qualifications were not of an order to make him prized in that hunt.

You will thus get a horse at a very moderate price, with qualifications first-rate for the country you in- 
tend taking him to, but which were uncalled for or thrown away in the one from which he came. These particular cases, as may regard more or less one or two horses of the stud, are only to be learned from the groom.

The mode in which you make inquiries, and the inquiries in themselves, will at once show whether you are one making them from idle curiosity, or for any useful purpose. For instance (and such instances do occur), if a man was to pester the groom with questions, and expect him gratuitously to answer them, he must expect to receive short answers; the man well enough judges such an inquirer to be neither a buyer nor a sportsman. Ridiculous as it may appear, I hare heard something like the following observations made and questions asked:-

"I want to buy a hunter-which of these would you recommend?"

Judging it would be of no use holding colloqny with such a querist, and also judging that it would matter little whether he was offended or not, the man would probably answer something in the following 
quaint style :- "You'd better buy them all, Sir; they are all good horses."

"Yes, but which do you think would carry me best?"

I can fancy the man scanning his customer, coming to the decision "You're a fool," and going about his business.

Now, we will go a different way to work. I look the stud over, then go to the groom: "Your horses do your master great credit as to sort, and you as to condition, groom; now look you here," slipping the five shillings in his hand, "I know they come from a heavy country, and your master rode heavy. I am but eleven stone with my saddle; I want speed, and high and wide jumpers; is there any particular horse that would carry me in the country I hunt in, that has been lost in yours, and with the weight he has carried?"

The man pricks up his ears, and says to himself, "This looks like buying." He feels it worth his while to attend to me, and it is ten to one but he says something to this effect :- 
"Here is a horse fast enough for any hunter's plate, and he can jump the world; he has carried my master, but was not suited to the country, and was overweighted with thirteen stone, but would fly with your weight. Here is another: they did not like him in our country, he rushes a little at his fences, and in a cramp country like ours, this is held as a great objection; now, in Leicestershire he would shine."

I have now got a bint as regards two horses, both as good as any in the stud, and in some points perhaps better; but, as the groom foretells, they would probably go for perhaps seventy or eighty, whereas others that would not answer my purpose better, or as well, would bring from two to three hundred-is not this worth giving a man a couple of sovereigns for? This I know, it is the only way for a man to go to work to whom price is an object. 


\section{TATTERSALL'S AND OTHER PLACES.}

I HATE ventured a hint to the best of my judgment as to the best way of each man setting about getting information to be depended on as regards purchasing from studs; but all are not studs that are sent to Tattersall's. There are single horses, two, three, or more, as the case may be, belonging to noblemen or gentlemen; the single horses frequently belong to gentlemen also, but as frequently to Mr. The-Lordknows-who. In some cases Mr. Tattersall himself • does not know the right owner : the animal is booked in the name of Brown, or anything else; and, to make the matter worse, the only directions sometimes left are, "The owner will attend the sale."

A horse left in this way is commonly the property 
of some low dealer, who gets his friends to bid him up to a certain price-any bid beyond that, and he goes. He has thus found an indisputable owner, and it is ten to one but a pretty bargain the new owner has of him. Tattersall has nothing to do but to receive the money of the purchaser, and hand it over on pay-day to Mr. Brown.

The purchaser may, perhaps, long before that time have discovered his having bought a roarer, a halfblind, or lame one. It is, perhaps, well for the purchaser if he has only one of these objections. The reply on Tattersall's part to any complaint made to him would be, "The horse was sold without any warranty, so I could not refuse the seller his money ;" and if you were well known to him, he would perhaps say, "How could you be foolish enough to buy a horse you knew nothing about, or anybody else?" Pretty consolation this: the purchaser has been put in a hole, and virtually told he was an ass for getting there.

I will here mention an anecdote; and, as it is to a certain degree against myself, there can be no 
offence to any one :-About two years since, I was much struck both with the action and looks of a particular horse that was being shown to some one, so I determined to buy him if he went for little money, wanting one at the time for harness; the horse was put up, and I bought him, I think for twenty-seven guineas. I must mention that I saw he was not at all lame; his eyes were good, his mouth showed seven years old, and for my further satisfaction I had seen him threatened, and the usual means resorted to by some one, and he showed no synptom of being a roarer : still I knew by the price there must be a something.

Presently a little fellow, with his stick stuck halfway in his coat pocket, came up to me.

"You have bought the bay oss, Sir."

"Yes I have."

"You don't know, I suppose, that he is a bull."

"Oh yes I do," said I, without hesitation.

"'Cos if you didn't, I would try and buy him of you."

"Well, you may have him if you wish; I have 
given twenty-seven for him; if you want him for anybody, you may have him at five and thirty."

"Lor bless you, Sir! I was thinking of offering you fifteen."

"It's devilish lucky you did not," said I, smiling. "Why, Sir?"

"Because if you had, you would very likely have got a punch on your head for your impertinence."

"Beg pardon, Sir," and the little gentleman walked off-he was beat.

Now the dodge was this : this little fellow had got hold of the intelligence from some source, that the horse made a little noise (and so he did, as I found in his fast gallop); but I only bought him for harness, and for that the failing did not show itself : when I had done with him, I sold him as a match at a fair price, though, as my little friend said, he was a bull. Now had I been a man not at once awake to the kind of trick the little gentleman wished to play me, and had I not had presence of mind enough to aver that I knew the horse's failing, I should have been told he would nerer answer my purpose, and 
been talked out of the horse at the fifteen pounds alluded to. But suppose a man has all his wits about him, the purchasing horses at Tattersall's, about whom you can get no authentic information, is buying at a great risk, and what no one should do who wishes to buy a horse that he may feel certain will answer his purpose.

It may be asked, How or why do dealers buy horses at a risk at Tattersall's? the answer to that is, respectable dealers do not buy horses of which they know nothing. If the horses of any known man are to be sold, the horses used by such a man are perfectly well known to all the first-rate dealers; they have seen them at work, and know their qualities; and when they buy such horses, it is usually on commission from some one who knows them also, or, when this is not the case, they have some one in their eye who they know wants such an animal. Whenever you see anything like the following advertisement-"To be sold by Messrs. Tattersall, at Hyde Park Corner, on Monday next, the following hacks, ladies' horses, and ponies, the property of a 
nobleman," with their names specified, be sure you cal buy nothing there worth your money. Lord or Mr. Somebody has seen them carrying their late owners and their families; he determines to buy one or more of them; he is not limited to price, have them he will; and, if two or three men are determined on this, cost what they will, the price is sure to be enormous-at least, enormous for the particular animal. He may not be strikingly handsome, nor anything particular as to action, or possess any qualification that a horseman would prize. The frequent fact is this : he has carried some old fogy, is perfectly safe, would not shy at anything in nature or supernatural, will stand still as a statue, and move on, when wished, like an automaton. Another old fogy knows this, and for such qualities will give any price; so, unless you are an old fogy too, if you were to buy one of these prized animals you might give considerably above a hundred for what to any but such a man would not be worth twenty-five pounds; in fact, each horse will under such circumstances bring a price that only particular persons would contemplate 
giving. By this I mean from a hundred and twenty to a hundred and fifty is often the price given for a mere pony, or rather galloway, with no other recommendation than ordinary pleasantry, and, above all, perfect safety to the rider, who peradventure was one of the Lord's anointed.

I have said that respectable dealers do not in a general way buy odd horses that they know little or nothing about; in the first place, a low price will not tempt such men to get a horse they cannot sell to their customers with credit to themselves and satisfaction to the purchaser. Without entering on the subject of whether their sense of rectitude may or may not influence them, a first-rate dealer would not dare, and we will do them the justice to say would not be disposed, to sell a very faulty horse to a customer; he would lose caste by so doing, and it would answer his purpose far better in the long run to give a hundred for a horse, and sell him at only ten pounds profit, than it would to buy another at forty and sell him at a hundred, which his looks and some of his qualifications might enable the dealer to do. 
But with the low dealer it is a very different storyhe has not often any regular customers. The horses he has are placed, as it may be said, in "holes and corners," from whence they issue when a purchaser is found; the man himself lives in "holes and corners," and when a sale is effected, no such man is known in either place: you may chance to meet him at some of the repositories, but to what purpose your doing so?-he is either civil, and pretends to be very sorry, or very impudent without pretending to be sorry at all. There are many such characters about the town : to them a good-looking, half-blind, or half-broken winded horse is a continual income, and gets into their hands, and is sold perhaps halfa-dozen times over. The purchaser buys him, we will say, at thirty-five guineas, which price he has been run up to at the hammer; after he has been paid for, and is perhaps being led away, up comes some one of the gang, and accosts the customer with "Have you bought that horse, Sir ?"

"Yes, I have."

"Why, he aint of no use to no one-he has been 
sold a dozen times over within the last three months." He then tells you what perhaps is the truth, that he is defective in his wind, or, as he terms it, regularly broken-winded, which he assures the buyer he will find to-morrow morning, when the effect of the dosing he has had is gone off. He then probably adds that he is restive, and "not fit for a gentleman nohow." The purchaser looks blank at this, and, whether he believes all the fellow has told him or not, he is quite convinced he is done. The fellow sticks to him like a bur. If the buyer, to avoid ridicule and exposure, orders the horse to be taken home, either the horse or the owner are closely followed, most probably the owner ; for the man taking the horse home is most likely in the pay of the coper, will tell him where he takes him to, and will further persuade the buyer that the man offering to take the horse is a very respectable man, and recommends the gentleman to take whatever is offered him for a horse "not fit for a gentleman nohow." The gentleman, if unused to such transactions, may wonder no little what the man can be so desirous to buy a 
badly broken-winded and restive horse for. If he asks this, he is told that the man has a friend, and " the horse, being a good-looking un, would do to draw his cart."

The result usually is, the coper gets the horse at his own price. He is then hid away till his appearance is forgotten, or that appearance so altered that it is next to impossible to recognise him; then some one else is accommodated with a bargain-nor can this be totally prevented. A man has a right to send - his horse to be sold by public auction; has a right to get his friends to run him up as to the price in the first instance, then to run him down as to his worth in the second, and to deal for him by private sale in the third. Sometimes the man, willing to ease the gentleman of his purchase, pretends to know the former owner of the horse, and mentions some fictitions name and person, to which he adds this encomium :

"Why, Lord love you! he would cheat his own father ; I wouldn't take his word for a brass farthing." . Probably adding: "Why, he sold me a blind'un not 
long ago, though he knowed I wanted him for a gentleman, a customer of mine; in coarse I could not let him have him; so I lost a hat-full of money." As Falstaff said, "Lord, Lord, how this world is given to lying." The fat knight was a tolerable hand at it himself; but I will back a regular coper to beat even him.

We will now quit Tattersall's, and will mention a ruse by which a man is almost sure to be taken in. Now at Tattersall's he only runs a risk of this in buying certain horses under certain circumstances; but in the way I am going to mention, he is as certain to be so as he would be if he purchased silks and satins at one of the advertising mock auctions-I cannot mention any greater certainty.

It should seem that people like to be humbugged: or whether they think that luck, or judgment will bring them through while tampering in such dangerous speculations, or whether they think that now and then a bargain is to be had, and hope the now and then will be in their particular case, I know not; but by their going to such places it should seem that the assertion is not very wide of the mark that says, that 
certain nameless persons are born every hour, and rogues prosper by the circumstance.

It may be a very true axiom that " the burnt child dreads the fire;" he may so, and if he does, he shows more sense than many "children of a larger growth ;" it may be the child will not take warning by seeing another burn his fingers, still less would he take advice if told that the catastrophe was sure to occur under certain circumstances; but if he burnt his own fingers, the chances are, he would in future keep them out of the fire.

Now, the children of larger growth will not take warning by others more than the child; still less will they take warning from what they are told, but they go still further-they will frequently burn their fingers several times over, before they become convinced of the folly of their proceedings. They seem to act upon the principle that influences the sapients who throw at the snuff-boxes elevated on sticks, at fairs and race-courses : though they fail ten times over, they are led by the saying of the man owning them, "Better luck next time." 
Perhaps, after another failure or two, they succeed, and a pretty success they have of it: they find they have got a tin snuff-box, or a wooden imitation of a pear, worth three-halfpence, after having expended perhaps a shilling or more in failures. Perhaps there may exist persous who have done pretty much the same thing, by endeavouring to get horses by a move pretty much carried on in and about London-which will be the subject of the next hint. 


\section{EXPERIENTIA DOCET (SOIIETIMES).}

“TO BE soLD, a beautiful dappled grey gelding. Has constantly carried a lady, is perfectly docile, perfect in all his paces, and is sold in consequence of the owner having gone abroad. To be seen at the - Kensington. No dealer need apply."

Whenever, or wherever, such an advertisement appears, avoid it, or rather avoid the horse and those advertising; for you will be done otherwise, as sure as you would come off with hurt fingers if you put them in a rat-trap. The mode and extent of the do would greatly depend on the person applying; and in such cases the seller, or probably sellers, of the horse form at once a pretty accurate conception of 
the kind of rictim they get hold of. If he is seen to be very young and very green, he will be doubly victimised-that is, as regards price and horse.

It is not at all unlikely that so very verdant a young gentleman will boast " that he does not mind price, provided he gets a nice horse." The owner, like Othello, may say, "Upon this hint I spake," and consequently names a price corresponding with, or rather exceeding, the value of the horse, if he was all his appearance would bespeak. If the young gentleman does "not mind price," why should the seller?

But Mr. Verdant will find that the latter does mind price very much, but in a different way to his customer; and the chances are they will both be indulged in this particular.

"Why, Sir (says the seller), I sees you knows a nice horse when you sees him, and will not let him slip through your fingers for a few pounds. Why, would you believe it, Lord __ saw this horse yesterday, wanted him for a lady; he rode him, could not find a fault, and then offered me five and forty pounds 
for him. Why, he must have thought me a rogue or a fool, to go to sell a horse trusted to me to sell at a fair price, for forty-five pounds. I was not over civil to my lord, for my dander was up, so I said, ' I wish you may get him.' I dare say he will be sending and offering a pound or two more; but he shan't have him unless he gives the full price. I axed sixty; now, if you take him, I will say fifty-five, 'cos I sees you're a gentleman."

"Well, I like the looks of the horse, I must allow." "Yes, but you'd like him better if you rode him. You shall have a saddle on him : there is some satisfaction in putting the likes of you on a horse, you knows what a nice 'oss is. Bill," calling to the man holding the horse during this precious piece of humbugging, "put a saddle on for the gentleman."

The horse having carried a lady is so positive a proof of his quietness, that Mr. Verdant thinks the riding him unnecessary; he has made up his mind to have him.

"Thank you," says he, "I will not give the man 
the trouble of saddling the horse. I think I shall make up my mind to have him."

Now, there is a vast difference between saying "We think we shall make up our minds to have a thing," and "We will have it." Seller knew this, and though Mr. Verdant had actually made up his mind on the subject, seller did not know this, so brings forward wbat seems an unmistakable proof of honest intentions, by way of a clincher, in this way :-

"Now you shan't have him till you have rode him. I don't want you to say you bought an umpleasant horse to ride, and that I sold him to you. Why I know you can judge of a horse in ten minutes, up and down the road here, as well as in ten hoursbring him out, Bill."

Now had Mr. Verdant said at once that he would have him, seller would not have cared one farthingr whether his customer subsequently liked the horse or not; but he knew he was pleasant to ride, and so perfectly quiet that the worst rider in Christendom conld not make him otherwise, and as he had specified ten minutes to be ample time for such a judge 
as he complimented Mr. Verdant by his pretending to think him, nothing doubtful was likely to arise in that time to cause suspicion on the part of his customer, particularly such a customer as Mr. Verdant.

The seller's fairness, nay (as Mr. Verdant thought it) kindness of conduct, in insisting on his riding the horse, lest he might get what he should not find pleasant when in his possession, was such that he thought the world illiberal as to the opinion often entertained of horsedealers, and would have thought them particularly so if entertained in the case of the seller of the grey horse. "To be sure," thought Mr. Verdant, "there is one thing to be said, he has no interest in deceiving me; he is only employed or authorised to sell the horse for the lady." Mr. Verdant did not seem for a moment to entertain the idea that the lady only existed in the seller's brain, and neither did exist nor ever had existed anywhere else.

A little reflection would have convinced Mr. Verdant, if he was to be convinced by reason, that a lady, in the habit of taking horse exercise, must have had a groom to attend her; also, in most cases, an establish- 
ment, more or less; and that her favourite horse, if to be sold under the circumstances stated, of her going abroad, would have been gladly purchased by some friend accustomed to see it carry the lady alluded to.

We will even suppose the lady broke up her establishment suddenly, and had not time to dispose of her equine property before she went, how came it that the very horse her friends and acquaintances would, in common phrase, have run after, remained unsold? The next thing that would strike any one of the smallest penetration would be, had the lady no gentlemen friends to whom she could leave her favourite for sale? Was it likely she would have employed a man whose appearances, manner, and language were at variance with those of any person with whom it is likely she could have come in contact?

Now, had this man dressed himself and represented himself as the late groom of the lady, and that her horse was sent to the place at which he was advertised, her stables having been giren up, in such 
case a more knowing man than we conclude Mr. Verdant to be might be taken in under such plausible circumstances,

I have mentioned these incongruities and unlikely features in the supposed case of the lady's horse, to show that there is nothing really too absurd, too unlikely, or too contrary to common sense, that, if advertised, will not find dupes to be taken in. I have specified the improbabilities existing in this supposed case, that persons not prone to reflect, or to combine circumstances, may see the necessity of so doing in any real case, as we will suppose it would have been well for Mr. Verdant had he done in the supposed one.

We are not to suppose those persons all simpletons in the ordinary occurrences of life because they are taken in by a specious advertisement; they are probably merely simple, or, in other words, unknowing in such cases. The moment the inconsistencies in many of these transactions are pointed out to them, they see the thing clear as noonday, and are surprised they did not see them before. They need not 
be; an inconsistency is only seen as such when pointed out; the uninitiated do not see it, not from want of sense, but from the want of being, in slang, phrase, "wide awake" in similar matters.

These observations, though they have taken some time to write, have whirled through the brain during the ten minutes we allowed Mr. Verdant for his ride: we will suppose him returned. "Nice 'oss to ride, sir," says seller, the moment Mr. Verdant stopped; this said in so decided a tone that really Mr. Verdant would have feared, if he had not agreed in opinion, that his knowledge of what a "nice 'oss" was would be called in question; so he corroborates seller's opinion by saying, "Yes, I like him very much." "I knowed you couldn't mislike him; but it is a satisfaction to me that you have had a trial."

It is natural to surmise the horse was taken, a cheque given for the money; and so soon as seller saw the horse on his way to his new purchaser's stable, and the new purchaser riding or walking by his side, as we suppose, admiring him, the seller was off to get the cheque cashed. 
Now, we are not to suppose the man leading the horse home to be totally silent, for, finding Mr. Verdant disposed to listen, he begins something in this way: "I didn't think you'd have got this horse for the money you give for him. I know the lady's groom what owned him, and he told me a hundred would not tempt his missus to part from him ; but," adding with a wink, "there was something wrong in money matters, so she was forced to cut her stick. Mr. Nip'em, who had the sale of the 'oss, was asking a deal more nor you give, but I told him keep was expensive, and you seemed a nice gentleman, he'd better let you have him a bargain, so I saved you twenty pounds any way."

Now a man who has saved us twenty pounds " auy way" is certainly entitled to a sovereign some way; and we will infer it was given.

We suppose $\mathrm{Mr}$. Verdant to have given fiftyfive pounds for his horse: he had not given more than the animal's looks warranted the seller in demanding; and it would have been even a very moderate price had the horse been what he seemed, or was 
represented to be; but Mr. Verdant shortly found it was a strong price for a horse with a disease, or rather failing, of which, after two or three days' rest, he would show no symptoms, but a day's moderate work, or rather exercise, would cause him to go as lame as if liis leg was broke.

In transactions of this kind a man has no earthly remedy. In the first place, if the seller gave a verbal warranty, he would deny it; and in such cases the seller always takes care that some one shall be present who, if occasion calls for it, is ready to swear none was given. This precaution the purchaser, in nine cases out of ten, neglects to take-so he is beat. But we will suppose he has even got a written warranty, worded as strongly as document can be-it is merely in effect a piece of waste paper. The man is a man of straw; you may find hin-bring an action, recover damages. What then? Not a farthing of your money can you ever expect or hope to see; and all you do see is a long attorney's bill of costs, or rather an attorney's long bill.

I knew an instance where a friend of mine came off 
even worse than this. He had bought a horse of one of these copers, or, as they are sometimes called, "horse chaunters." Of course he was done. The fellow was very sorry, and very civil. Was sure "he thought the horse what he represented him to be ; he had not the money by him or he would return it without hesitation; but he would tell my friend what he would do. Colonel (somebody) had seen the horse before my friend; had come the day after he was sold to buy him. He did not care a brass farthing for the Colonel; he would tell him the gentleman he had sold him to found him a bit too gay for his riding; and that on receiving a five-pound note he liad taken him back."

My friend's conscience made an appeal that this was shifting the load from his own shoulders to those of some one else. I am not writing a system of ethics, so leave persons to decide how far my friend was justified in countenancing this mode, as he thought, of getting out of a scrape; be that as it may, the coper came down next morning for the horse, and took him away for the purpose of doing the Colonel. 
My friend's conscience need not have troubled itself or its owner, the Colonel was in no danger; but my friend was not only in danger, but, as Jonathan has it, "in a pretty considerable fix," for the fellow took the horse with my friend's concurrence, but he also took the money he sold him for without it; in fact, he never got sight of him for months. Inquiries were useless; persons who knew him well enough hy sight, and also by character, knew nothing of his " whereabout;" but they knew enough of the fellow to give my friend the consoling assurance, that under any circumstances he might consider his horse and money gone. It was at best but a breach of trust. He had taken the horse with the owner's consent; he had failed to bring the money the horse sold for; he had not promised to do so, so perhaps, after all, it might be only a debt; and in alluding in another place to these gentry, I have stated the usual result of going to law with them.

'To cut the story short, my friend got sight of him at last; he put a good face on it-he came up with a story ready cut and dried. 
"The day after he received the money for the horse, he went off to a fair in Belgium, intending to buy some horses; he knew a few days would make no difference to my friend, and that he would not mind his using the money. He fell in with some gamblers who had regularly cleaned him out; he hoped to make some money soon, when my friend might depend on it he would make it 'all right' with him."

Of course, not one word of this tale was true; and it ended in my friend being tired of asking for his money, so he ceased to do so. The fellow no doubt guessed how it would be, and after a time used merely to touch his hat when they met, as if the affair was settled; and so it was, and so it ended.

Thus, though the supposed Mr. Verdant's case was a bad one, there are few things in life so bad, but they may be worse, the real anecdote of my friend proving it. Mr. Verdant had not shown any absolute want of sense-he had merely shown a want of knowledge of the world, of men, and particularly of the class of men of whom the vendor of the grey horse was a hopeful specimen. 
As some balm to the self-pride of any who may get into a similar predicament, let it be recollected that no man living is, nor can be, awake to the tricks and rascality of all classes. The man who could judge the weight of jewels to half a carat, and their value to a sovereign, would be a perfect muff if he ventured on the Stock Excliange. The man considered the most knowing of the latter place would be, perhaps, a mere child as to knowledge in purchasing horses. Thus it would be seen each man is knowing enough in things and matters with which he is conversant, though showing as all but a simpleton in regard to those to which he is and has been unarccustomed.

The intention of this paper is to put people somewhat on their guard against being taken in by advertised horses. From habit and experience, I think I may say that in nineteen cases in twenty I will form a shrewd guess at something like what I should see were I to go to any advertised horses. Not, of course, that I mean in any way to insinuate that horses and advertisements are to be feared or avoided; I only 
mean that from the style of the advertisement I would in most cases detect the black sheep.

If I were to see a large consignment of tea to be sold at Messrs. Debenham's, in King Street, I should, at all events, be certain it did not come from Messrs. Twinings, or Antrobus; and, not being a judge of tea till it is made, if I rentured to buy there I could but anticipate getting sloe-leaves flavoured with the produce of the black currant; or again, if I sam several cases of champagne, or a pipe of port or claret, to be sold for half its value at the Dog and Fiddlestick, in Drury Lane, I could but expect to get expressed juice of gooseberry or rhubarb representing the one, sloe juice, logwood, and bad brandy to give strength in the other.

Genuine and good articles and animals are often, nay constantly, advertised; but great bargains in either, I may say, nveer are. There is an old saying, "good wine needs no bush ;" any thing good that the owner determines to make a sacrifice of, and sell at far less than its value, needs no advertisement. There are as many persons on the look out for, and 
willing to purchase, a real bargain, as there are dupes Jeady to run after fictitious ones.

These hints and representations will, I trust, if kept in mind, be useful to those who do not wishin accordance with the saying-to be "done brown ;" and, if attended to, will greatly tend to Mr. Brown being done, that is, his trade spoiled-" a consummation deroutly" to be wished. 


\section{WHAT IS A GOOD SORT?}

To describe a good sort of horse (abstractedly as an animal) may not be-in fact, is not-to any judge a difficult matter. A really good sort of horse cannot well be put quite out of his place; he is capable of, we may say, all services that can be required of him, with the reservation of the two extremes-racing, or the waggon. Even for these, if he is well bred, he would make a tolerable good fight for the one, and his pluck and courage would, to the extent of his strength and weight, make him a most willing rival of "Gee woa," if the ingratitude and cupidity of man should destine him to such degradation and (to him) suffering-no improbable ending of his career, and 
that often under circumstances at which the feelings of any true sportsman must revolt.

Lottery-the ever-to-be-respected and esteemed Lottery - the best of steeple-chasers, and one of the best of animals - we say one of the best (for old Vivian at one time, perhaps, ranked as high in intrinsic goodness)-Lottery finished his career in a hay-cart. But let not the reader's feelings be excited to unmitigated commiseration on hearing this.

We are not to suppose that the lorse is sensible of degradation, provided he is well and kindly treated; we must suppose him just as happy and contented with cart-traces on him as with the silk jacket; and, to the immortal honour of Mr. Hall, to whom Lottery belonged in his latter days, he would no more have permitted the old horse to suffer in any way in his capacity of cart horse, than he did when wimning the Liverpool and other races from some of the best horses in England. Perhaps his latter life to the horse was one in which he suffered the least. Mr. Hall seems to have established a kind of home or retreat for steeple-chasers on his farm, for Lottery 
was not the only one there. May his example be imitated by others; numberless good animals would thus be saved from merciless cabmen and others.

There can be no doubt but that a good sort is a raluable acquisition to any man who wants a horse to perform well any purpose for which such sort, is necessary or desirable; but he may not get what performs a particular kind of work in a superier mamner notwithstanding; and we may sometimes, and under peculiar circumstances, show our tact and knowledge of horses, by purchasing one for a given purpose that our judgment may tell us is really of a good sort (as an animal) even for that purpose, or indeed any other. This may appear somewhat anomalous-in fact, in contradiction to the observations I have made on the subject of sort; but be it remembered I head this by a question-namely, "What is a good sort?"

A really good sort of horse, as I have stated, is fit more or less for any purpose to which we may apply him, and will do that purpose moderately well ; but it by no means follows he may be more than ordi- 
narily good in any of them. A good sort of horse has so often been described by abler pens than mine, that we will not enter into the minutiæ of description here.

We are told, and with truth, that a thin, clean, good head, and cheerful eye, are indicative of goodness, and (if I might use the term as allusive to the horse) indicative also of an amiable and generous temperament and disposition; a head well put on, with a yielding and somewhat arched neck, bodes the head being capable of being carried in the right place; and, further, we may infer such a horse has a good mouth, it not having been hardened or spoiled by useless endeavours (where this is not the case) to bring the head in the place we wish it to be. Long oblique shoulders usually betoken freedom of action, so far as the fore parts are concerned. A deep girth and long back ribs show strength, as does good loins; wide hips, freedom of action; long good thighs and large clean hocks, with hind legs well put on, show strong propelling powers.

With these points, without going further or inquir- 
ing into causes and effects, we will say a horse lias got what indicates goodness of temper, cheerfulness, and courage, carrying himself handsomely and pleasantly to the rider or driver, goodness of action, strength, speed, and safety.

Yet, with all these good points, he may only be enabled to perform any of the purposes to which we may put him moderately well. We will allow that in a general way such an animal cannot be a bad horse; but if we want perfection, or something like it, for a particular purpose, we must tie ourselves to no rules as to formation, and should, as I say, show our tact in buying what our judgment must in a general way condemn, if we determine to have something uncommon in a particular way, for instance.

We may see a cabriolet standing at a door. As horsemen, we will suppose we naturally cast an eye on the horse ; and having done so, though, of course, we must suppose that for the cabriolet of a gentleman he must be at least good looking, still the critica eye of the judge may cause him (looking at the horse 
as an animal) to exclaim, or think, "What a brute!" A head that you may see would be with the bridle and winkers off and the large bit out of his mouth, as big as a coal-scuttle; a bull neck set into the wither without your being able to decide where the wither begins or the neck ends-this fault the collar hides, to ordinary view, but the judge sees it is there; narrow and consequently weak loins-this the breeching straps and crupper hide; miserable thin thighs, bad gaskins, and equally bad hocks, and those badly placed-all this, to the ordinary passer-by, is hid by the splash-board and shafts.

We now come to his body : small in the girththis does not strike one in a haruess horse "like one under a saddle; short back ribs, and those a long way from the hip bone-this fat and condition hide (that is, condition so far as full feed and little work produce a state that, with a good and glossy coat, is mistaken for condition). Now, among other things, short back ribs, and those placed far from the hipbone, are proofs of weakness in a general way, and, if a horse has little flesh to hide the imperfection, 
cause him to look like a half-starved greyhound; and this such a horse as the one described would certainly show, if worked; but the purpose for which he is used cannot be called work. So far we may infer that a really bad sort can perform certain purposes.

But why, some one may ask, buy such a faulty animal when a better sort is to be had? No doubt a better sort is to be found, and we all know found easy enough; but perhaps a better sort with the particular qualifications of this brute may not be readily found.

A thorough judge, as I have surmised, might say, "What a brute!" and if an unthinking man, might add, "I should say the owner of that horse does not know what a horse is, or, if he does, I suppose he got him for next to nothing" - adding, by way of parenthesis, "I would not give fifteen pounds for him for an omnibus."- "No man would," replies some more thinking man; "he is not fit for an omnibus, though, perhaps, very fit for the purpose for which he is used."

In the midst of this colloquy the owner of the 
cabriolet comes out. "Angels and ministers of grace defend us! why it is Lord Gardner."

"Ah, ha! my friend," cries the more thinking individual, "you see the owner of this brute does know something about horses; he knows his horse is not fit for an omnibus quite as well as you do ; he would not give fifteen pounds for him if he was buying horses for such purpose; but he has given a hundred and fifty for him for his cabriolet."

The owner gets in, takes the reins; up go the horse's head and tail; he moves off gracefully as a swan taking to the water, with action only to be surpassed by Carlotti Grisi in her movement in a pas seul. The big head, bad shoulder, weak loins, faulty thighs and short ribs are lost in the admiration excited in the by-standers of his magnificent and elegant action. His owner has shown his tact in purchasing what it cannot be denied is a bad sort for general purposes, but a rara avis for his.

In one word, a good sort betokens a good horse; but in employ where goodness is not called for, agood sort may be dispensed with, if they happen to pos- 
sess the peculiar attribute we want for a particular purpose.

And again, where show is the desideratum, there are many horses strikingly handsome at first sight, that will not bear, in figurative terms, "picking to pieces;" for, to carry on the metaphor, if they underwent such process, we should find we must put them together in far different way to form half a good sort.

Some thirty-five years back there was a description of horse much in use quite illustrative of this: I allude to the barouche-horse, as he was thus termed. He was not to be described as a coach-horse, though he occasionally drew a coach; neither is he represented by the kind now used in broughams. The old coach-horse was, if we may judge by a few portraits (still at times to be found of him), an undeniably good sort for the purposes for which he was used.

We see some handsome and good-looking horses in broughams now; but the barouche horse was neither of them. I will endeavour to describe what he was. Nine pairs out of ten were then bays, of 
some shade. This arose from George the Fourth (then the Prince) driving such. The sort were first brought in by Sir John Lade, the then fides Achates, box-companion, and amateur gentleman adviser to the Prince in all matters wherein driving was concerned. Then came the original Lord Sefton. He patronized bright-in fact, light-coloured-bays, many of them with more or less white legs; and, though such are usually objected to for harness, they looked well together.

The Prince, Sir John, and his Lordship at that time "bore away the bell" in the magnificence and merits of their teams, who, coming along the carriage drive in the Parks the pace they did, with their high action, seemed, figuratively speaking, likely to step over the iron gates at the end of it. They ranged from sixteen hands to sixteen two, and their action was all alike. The sort and required action were so well known, that any dealer having one come into his hands was sure of a customer, by making it known. The reader must not infer from this that either of the teams was comprised of "a good sort;" they were 
collectively very much the reverse. It is true they were mostly highly bred-many of them quite well enough so, to be fitted in that particular to cross the fastest countries in England. Many of them had perhaps speed enough to win a Hunter's Plate; but they were most of them great overgrowu horses, that lad run to height without regard to substance. They were always in high condition, arising from a great number being kept to do the work; so none of them were seen, if at all, in stable language, "below themselves." Their condition and harness hid a vast number of imperfections; but if even seen, their style of going made you overlook it.

There can be no doubt that, if a man had had permission to pick the stables, he could have found among them a horse or horses that would have made first class hunters; but it would have been but few, for if he saw these horses out of their harness, and consequently out of action, he would have found them to be great, long, gangling, flat-sided, lightbodied animals, that though imposing enough to look at side-ways and going, if looked at standing, still 
from behind, might be characterised by their own stable-door looked at edgeways. They were a sort that, in dealing plirase, "would do well enough for leather." They. did more than this-they did magnificently for it, and magnificent prices such horses would bring, and they were worth it for particular men, and particular purposes.

It is not to be supposed that the Prince, Lord Sefton, or Sir John, were not perfectly aware that the horses they used were not of a good sort; each knew it, but they found it impossible to obtain the show, speed, and action, they made it a point every harness horse they used should possess, combined always with "sort." As I have stated, all might be found occasionally in one animal, but not in all they used and wanted; so if they got (and have it they would) the show, speed, and action, as in the stated (supposed) case of the cabriolet horse, they were content in harness horses to forego the other points.

These persons would, when appearing in the hunting field, be as particular as to sort as man could be; and no man rode better or finer horses 
than Lord Sefton, when a hunting man. And though, to use the words of a sporting character, "they go in all forms," he well knew this was the exception, not the rule; and, in a general way, sort is indispensable with the hunter.

Now the Prince, though using the kind of harnesshorse I describe, would not make any sacrifice for show in his hacks : here he would have sort-in fact, a horse owning any fault in his shape that showed a want of power, activity, safety, and pleasantry of action, would not have been looked at. The Prince's judgment was too well known for such a horse to be submitted to his inspection: a man riding twentytwo stone, who would have a hack carry him with (comparatively speaking) as much activity, safety, and pleasantry, as if he had ten stone on him, must have no commonly made animal, "let alone" (as Pat says) a fanlty one.

I just remember, as quite a boy, seeing the Prince on his celebrated hack Tiger. He was coming down Constitution Hill, at something bordering on fourteen miles an hour, with quite a loose rein, and chatting 
to those galloping by his side, with as much confidence in his favourite as if he were riäing him feather weight. 'There was no weak loins, small girth, short back ribs, poor thin quarters, here. I do not allude to the Prince (though, in sooth, the same might be said with truth of him), but the hack.

"Tiger scorns to fall," or words to this effect, was his Royal Highness's remark when it was represented that the horse's fore legs were getting weak, which showed that the Prince's confidence in, and attachment to, his favourite was not to be shaken; what reasons he might have for not showing the same lasting attachment to other favourites is not for me to hint at.

Lord Sefton's grey park hack I well remember, in days when, with Lady Sefton and his daughters, he showed an example of family unanimity that was well worthy imitation by noble families. He showed no want of judgment in the qualifications of the animals he selected for the use of the ladies of his family. Many more brilliant members of the aristocracy have succeeded him; but none in whom the genuine good 
qualities and sterling merits of the English nobleman have shown more conspicuously.

Though the allusion may be somewhat coarse and homely, I hope the spirit of it will excuse me when I say his Lordship and family "were of a good sort." Would we had more such.

We will now, in contradistinction to the baroucher, mention a harness-horse of really a good sort, much in use at the same time that the barouche mania was in force. This was the Stanhope horse, then in fashion, and a neat, active, close-knit horse he was, as well calculated for a liack as for harness. $\mathrm{Mr}$. Stanhope, from whom the vehicle took its name, shone pre-eminently in this kind of horse; his roan, with the then short tail and mane in vogue with hunters, was a totally different animal to the lengthy barouche horse, with the long tails first brought in with this horse; there were scores of most useful horses then used in Stanhopes.

It may seem an easy thing to rival a man driving one horse in a gig: yet it was found difficult to pro. duce a turn-out that in all points came up to the 
Stanhope : in most cases, either in horse, harness, or carriage, a something was wanting with the imitators, added to which, the perfectly, nay peculiarly, gentlemanly look and manner of its owner, formed a part of its peculiarity. But we must not award all credit to the Stanhope drivers for using "a good sort," more than we must censure the barouche drivers for putting up with what they knew was the reverse. One or two good sort of horses for a particular purpose it was quite easy to procure, whereas a number with all action alike, and that of a peculiar kind, was as difficult; therefore to get this sine qua non some sacrifice was necessary.

I have endeavoured to show that though " a good sort" will do anything moderately well, "sort" alone will not make a horse pre-eminent in every use, or rather purpose, to which we may apply him. There can be no doubt but that four horses of a good sort would, in three months' real work, "sew up" four of the sort isually then used in the London barouche; but then (as a general case) they would not look as imposing, or come along the park drive in the same 
style as horses chosen for this particular purpose. We can only say, therefore, that there are many horses that, for ordinary purposes, or for other particular purposes for which peculiar appearances, action, and attributes are wanting, are, like the barouche horse, a bad sort in themselves; but we must, figuratively speaking, call them a good sort-id est, for a barouche. 


\section{A FAIR BEGINNING.}

There are certain situations in which a man may be placed that, without their being in any way anything uncommon or difficult in themselves, are to the uninitiated most embarrassing. We will instance a few. A man having to come on the stage merely as a walking gentleman, has nothing in it that need alarm any one accustomed to society. Let the dropscene be down, he will enter with perfect propriety ; raise it before his entry, his self-possession is all gone. He, in figurative phrase, scarcely knows "whether he is standing on his head or on his heels," unless he convinces us of his consciousness of the latter being the case by (as has been done) taking to 
those heels and ruming off. It is the eyes of other people that cause his terror.

A young countryman is in the same predicament if asked to stand up in a quadrille, if (which with lads brought up at home in the country is sometimes the case) he has never been under the tuition of Mr. or Monsieur Firstposition. He may be gentlemanly in manners and well-informed ; but the consciousness of his gaucherie makes him look and stand like a simpleton, the more so from the eyes of the charming girl on whom he hopes he has made some impression, being upon him, he is aware all his prior attention goes for nothing. She turns from him with feelings bordering on disgust, for she is aware the eyes of others have seen his embarrassment. She is ashamed of him.

A man unused to refined society, if peradventure from some chance he is taken into it, is still more to be pitied. He can but feel that somehow he does nothing like other people, who cannot help certain looks of wonder at what he does do; and, if he detects an involuntary smile from some one, he inwardly 
wishes the floor, like that of the stage, had trap-door in it for his particular use and convenience.

Now, a man going for the first time to a fair is, mutatis mutandis, in the same category of nonhabitués. It may be said with truth a man requires no usage de théatre, no knowledge of the intricacies of the quadrille, no knowledge of the thousand and one acts that show a man to be, or not to be, accustomed to refined society, to enable him to go to a fair to buy a horse or horses: doubtless it does not; but even here the feeling that he is under the eyes of others prevents his being at his ease.

We will suppose he drives there in his gig. For the last two or three miles before he comes to the town the cottagers by the wayside are out to see "who goes to the fair ;" yelping curs, disturbed by the unwonted traffic on the road, assail the wheels of his vehicle; little urchins halloo or hurrah as each passes them, or run by its side tumbling heels over head, in hopes of some halfpence being thrown them ; carts, freighted with country lasses and their friends, return the huzzas sent after them with double interest; 
horsemen by threes and fours pass, or are passer, while with stentorian lungs they keep up an astounding talk (for we will not call it conversation) among themselves ; odd horses, or led ones of twos or threes (not strings, for they are long since located), are seen going to the fair, some of them creating a laugh ut themselves-in other cases, the men taking them indulging in a laugh at the expense of some unfortunate wayfarer on the road.

On entering the town, horses neigh, donkeys bray, pigs commence to squeak - all seeming by joint effort endeavouring to drown the efforts of Richardson's band. All this shows that whoever goes to a fair must be prepared to meet the public gaze unflinchingly.

Arrived at the inn, the man unaccustomed to such places inevitably expects ostler, waiter, perchance the landlord, or landlady, coming out to welcome him. All these functionaries and their assistants; if they could be divided and subdivided, would not thus be able to attend to the calls of each guest. Finding application at the front door useless, he dives into the 
yard; there, fortunate he that can get the harness taken off his horse, and, with a pretended "whisp over," doubled up with another-the ostler trusting to their being too closely packed to kick, swears the one by his side is "as quiet as a lamb," though possibly he never saw him before. After waiting till a similar process has been gone through with the nag of a more recent comer, you obtain a feed for your norse, his companion making powerful efforts to share it with him; this the ostler pretends to prevent by "tying him up short."

A good deal depends on what time of the day a man goes to a fair. The dealers, that is, men who go to buy $1000 l$. worth of horses, have nearly finished their day's work before the majority of those persous who come to look for a horse arrive; the latter never dream of going into stables to look for liorses on sale, but fully expect to find them parading the street or tied up to lines pitched for the purpose of fastening horses to: They are not disappointed in finding horses in plenty: but men who have horses worth from 120l. to 170l. apiece do not tie them up like 
strings of onions. The tyro would wonder where the great London dealers got horses from at fairs, for he would think that either horses looked to great disadvantage there, or that he wanted discrimination in not seeing them from others. It is not likely he should; by the time he has arrived, first-rate horses, that have been purchased by first-rate dealers, are on their road towards London, or more probably to some place where they will wait for a second batch of second-rate horses, purchased by the same person. Lower than horses of this description first-rate dealers seldom go.

Then come a second class of dealer, probably in point of respectability of character ranking as high in public estimation as the first-the only difference being, that from some cause, his customers are of another order, probably an order that pay them at once for any horses they may purchase, and take care they get the worth, or as near it as they can, of their money, when they do buy. Such men will not give a couple of hundred for a horse on their $\mathrm{I} O \mathrm{U}$, or 
omething of the kind, that for ready money they could purchase at far less.

A young man of fashion, and perhaps of large fortune (when he comes into it), sees a horse that strikes his fancy-he has not the money at command, nor will he wait for anything he fancies till he has-he must expect to pay a somewhat heavy price for being permitted to indulge his impatience. We are not to suppose that the transactions of first-rate dealers are always of this kind; but they are always with firstrate men, and such men have peculiarideas as to what they expect those they honour with their custom to permit them to do.

Besides this, men of note and fashion are very fastidious; in what they buy they will be (and they are right in being so) distingué; and to show them what ordinary men would buy of any kind-from a horse to a paper knife-would be useless. They are willing to pay for a thing being uncommon-and uncommonly dear they do pay for its being such. This forms the difference between a fashionable firstclass dealer and those of the less fashionable sort: 
each lays in such stock as he knows will suit his customers.

Second-class dealers buy a few of their best horses at prices, I should say, ranging from fifty to seventy, and larger numbers helow that price; a few of the best they purchase in the stables - those have been declined by the first-class; their other horses they select from those "standing the fair."

Our tyro need fear no interruption from dealers of the first or second class : the first he probably never sees, and if he did, there is no rudeness to be anticipated from them; the second class he does come in contact with in his perambulations through the fair, but they also are far too respectable a class of men to offer any affront to one they see in the position of a gentleman. But ware the lower sort: they hold a man buying for himself as virtually robbing them of their profits. Such men as Mr. Anderson, Elmore, or Collins, care not a farthing whether a man buys a horse or two or does not; they know he would not be there if he was one of their customers, and they would probably good-naturedly mention any 
horse to him that they had seen and fancied would answer his purpose, though he did not theirs; - at least so I have found it when occasionally I have gone to a fair.

But we have forgotten our supposed tyro while stating what might be seen at a fair, not what he has seen there. We suppose him to have come latish in the day, that is, one or two o'clock-quite time enough we will say for those who come there for amusement and sight-seeing, but by no means early enough for those who come horse-seeing; for by the time such a person has wandered about not exactly knowing where to look for what he wants, half the low rabble and low dealers will have got their dinner and just drink enough to render their address and jokes most annoying to any one they may think proper to "chaff a bit." Our tyro has looked at all the horses tied up for sale till he recognises the tails and rumps of them all, and has passed and repassed their owners till they seemed to him as old acquaintance. He has seen several horses out, and, judging from the aforesaid rump and tail (which are all he 
could judge by), each of those would suit; but he fiuds that the little square white-bound-with-red quarter-cloth, with its showy fillet strings, has so set off the rump and back of the horse, that, when shoved back and his fore-part is brought from the elevated position in which they were, and are seen on a level with his hind ones, the commanding forehand becomes commonplace, and the body so formed as to indicate that a man on it would be sitting on an inclined plane with the highest part behind him. He won't do, so is allowed to join his companions. A crack of the dealer's whip sends the whole of the string up to their places, from which they had somewhat retrograded to ease their aching loins and legs, from the tension on them caused by the elevation of the ground under their fore parts.

"Who-ho, ye high-bred rogues!" cries the dealer, seeing them all right, and some looking back at him or his whip. "Well," cries the man, "you thought the brown horse low before : this chestnut ain't that; he has a forehand fit to carry Prince Albert. Put him back, Jem." 
Jem brought the horse out.

"Why, he has but one eye," said our tyro, who, tyro though we suppose him to be in going to fairs, was not tyro enough to buy a horse with a large cataract in one eye for a sound one.

"Well, he has a little speck on that eye, but he sees as well with it as t'other," said the dealer, waving his hand across the eye with a motion that caused the horse to wink at the wind occasioned by the passing liand, though he could not see a load of hay if placed before the eye. "There, you see, he sees well enough."”

Our tyro was somewhat sceptical on that head, so wisely resolved to decline him.

"Well, come," says the dealer, "I shall please you at last, leastways I'll try.-Jem show out the bay horse. There the lamps are all right there, and he ain't low before."

"Well," says tyro, " he looks more like the thing; let me see him move."

Now the dealer knew well enough that the horse would gain nothing in any man's opinion by being 
seen in motion; he was, in short, in low phrase, "a thundering bad goer ;" so, in order to elate him, and cause him to exert himself, he off' $d$ with his hat, and, in low dealer fashion, with the handle of his whip in it, he rattled away like a mountebank playing on a salt-box; but he unfortunately overdid it, for he caused the horse to rush forward before, in horse phrase, "he got on his legs ;" and he made a most awful blunder, as good an attempt at coming on his nose and knees as could well be, and, though he followed up the horse, going and returning, rattling away, whip and hat, it did not do-it was, in fact, "no go."

"I don't like his action," says tyro.

"I put him up," says the dealer, giving the horse a cut with his whip that caused him to blunder again ; and turning to tyro, he added, in no very conciliatory strain, "I'm blow'd if I think you know what you would like."

He had mistaken his man in tyro; he saw he was not in the habit of going to fairs, so hastily 
concluded he knew nothing of horses. He was mistaken.

We may now fairly suppose it to be three o clock; our hero feels disposed for something to eat. Now as what happened to one man may happen to another, I will mention an anecdote of Stourbridge fair, which shows it not to be (at fair time) a town remarkable for the moderation of its charges. It was the first time of my going there; but, wanting a galloway for my wife's use in harness, I went. It was two o'clock before I got there. However, in about an hour I had made my purchase, and sent it to the inn. I then walked up-stairs, and in a long room saw a table-cloth remaining, with sundry appurtenances, in the shape of salts, cruets, \&c., bearing evident symptoms of a large party having dined there.

On the waiter making his appearance, I inquired if a large party lad done so.

"Oh yes, sir," said he, "the gentlemen all dine together when the fair is on."

Now the gentlemen, though quite carrying its import with it to the waiter's mind, did not so 
to mine; I ventured to inquire, "What gentlemen?"

"The gentlemen dealers," he answered; "this is their room."

I expressed a fear that I was an intruder.

"Not at all," he said; "other gents often dined with them."

Finding there was nothing to be had but the halfcold debris of the repast, I ordered a mutton-chop and some ale. On calling for my bill I found that was unnecessary, learning from the waiter's lips that I had seven and sixpence to pay. I thought this, even in fair time, an unreasonable charge, and said so.

"Why, you see, sir, there is four shillings and sixpence the dinner, and three shillings the pint of wine; those gentlemen who take more, make a whip for it."

"But, my good fellow, I did not dine with them." "No, sir, but you might have done, if you wished." "Well," said I, "but what do you say to the wine? I have taken none." 
"No, sir; but you might have done. We charge all alike who dine in this room, provided they don't exceed their pint of wine."

I thought the imposition so barefaced, so truly ridiculous, and the cool yet perfectly civil explanation of the waiter so unique in itself, and unprecedented, that I could not, for the life of me, make a serious affair of it. We will hope our tyro came off better.

We will suppose he has, and resolves on making another attempt to get what he came for. We have instanced his success, or rather want of it, in one quarter; why he had no better in others, must remain a secret. Whether his appearing astray induced the dealers to suppose they might show him auything, and they consequently did not show him their best horses, fondly hoping he would buy one of the worst ; whether a natural, and, in fact, a gentlemanly, dislike of some half-dozen tonts or friends of the dealer interfering with his purchasing, caused him to quit the scene altogether; or whether feeling his temper rise at impertinent observations and gibes of such fellows made him avoid a scene in which a quarrel would 
only have involved him in altercation with a set who would be sure to support each other, and by whick he would only subject himself to low ridicule, if not abuse-we know not; but he deternined to have nothing more to do with the regular low dealers, but would try and find among the single horses he had seen being ridden up and down the fair for sale, something be might buy, treating only with the person in cliarge of it.

Seeing a good-looking bay horse going down the street, with a bit of ribbon in his bridle, which he liad already seen enough of a fair to make him aware indicated the horse was for sale- "Young man!" said he, calling the attention of the rider.

Now a word shows those accustomed to such places whether the speaker is, or is not so ; if, instead of "young man," he had said " bay horse," it would have told the rider he was addressed by one accustomed to the usage and diction of fairs: however, "young man" pulled up.

Now a man accustomed to this kind of thing on the horse stopping, walks up to him, asks a leading 
question or two, such as-Does he go in harness? What's his age? To whom does he belong, and the price? Having ascertained these points, he perhaps measures the hor'se by the usual mode of seeing how far lie comes in a line with the intended purchaser's nose, mouth, or chin. Such men, from habit, will tell the height to half an inch: he then carefully walks round the horse, casts a hasty glance at him before, behind, and sideways: if he sees anything decidedly objectionable, he merely says, "Thank you, go on," and walks away; if, on the contrary, he is for the time satisfied with what he sees, he then, and not till then, probably says, "Trot lim twenty yards."

Liking his action, he then further says, "Just bring him to the end of the fair, out of the crowd."

This the man will do, seeing he has one to deal with who knows what he is about, and further, seems determined to buy if he can.

Now it is not to be supposed all this can have been done without a hundred eyes having been on the intended purchaser. This, if accustomed to the thing, he cares not a farthing about-probably he has not 
noticed them; and if he has, is as cool and collected as if he were a mile from the scene of action. He desired the horse to be brought out of the crowd, merely that he might make a more minute inspection, see his paces, and, if he thought fit, throw his leg over him. The difference between the two persons doing the same thing was this-our tyro requested the horse to be taken to a certain place before he had made any inspection of him, from the dread of the eyes of the multitude being on him. The consequence was, that, on seeing the horse at his leisure, he found him two inches below the height he wanted him. He said so: and the answer he got was, "You had eyes in your head, if you knew how to make use of them." A shilling to the man would have saved, we must allow, this just, if not courteous remark. Our tyro did not value the shilling to prevent his giving it, but he was not accustomed to the usages of fairs. Our hero does not seem to have got on better with single horses than with those he saw tied up in tens and twelves.

Returning, he saw a most promising-looking bromn 
being exposed for sale in a similar manner to the bay. He hailed him, not as we say, "Brown Horse!" but in some way equally showing himself not "at home" in a fair. He was told it belonged to the Reverend Mr. Somebody, ten miles off. A horse sent by a member of the church boded, or ought to bode, his being what he was represented by the pretended servant of the divine; in charity we will suppose that if sent by such holy person, he would be so. After getting the horse out of the fair, a person comes up, and addressing the man, says-

"Come, you had better take my offer ;" and, producing a handful of (we will suppose flash notes), adds, "Five-and-forty is no bad price."

"Thank ye, Sir, can't take it," says the man.

Then up comes a very gentlemanly-looking nan, and addressing our hero, says, "I should be sorry to interfere with you, Sir; but should you not agree for the horse, would you be kind enough to buy him for me? I will wait at the inn opposite; the fellow was most impudent to me early in the day, and I don't want to have anything to say to him." 
Now Tyro, though unused to fairs, was no flat; the fellow had overshot his mark, added to which, Tyro had read of similar tricks having been played off on the innocent. He wisely resolved to have nothing to do with him or the horse of the divine, said so, and turned on his heel-his pace somewhat accelerated by hearing "There he goes!" from some one, and, turning to see from whom, the very gentlemanly man was taking a sight of him.

He ordered his gig, vowing he would never enter a fair again, and above all other fairs, Stourbridge. 


\section{SEEKING A STUD.}

IT is some time since we left the young gentleman who sold his stud, or rather his friend did so for him, at Dixon's. Whether since then he has been indulging in the dolce far niente, whether he has found other pursuits in London, or whether he has treated himself to a trip up the Rhine, whence, if he went by himself, and trusted to lis own astute observations on what he saw, we may infer, from what we have as yet seen of him, he came back about as wise as he went-we know nothing of his latter movements, nor can they be a matter worth inquiring into by anybody. He answers our purpose, which is showing what a weak young man would have been likely to 
do in the supposed circumstances in which we have represented lim; and we shall take the liberty of making further use of him, to show what he or some one similarly organised about the head would probably do in future.

Our reader has not, we hope, forgotten Mr. Verdant, who purchased the "beautiful dappled grey." We did not represent Mr. Verdant as a particularly weak young man; he was merely not awake to practices that have duped many a clever one.

The young gentleman who went to Stourbridge Fair was rather a knowing hand - a fair judge of a horse, though a bad judge of a fair. He was, as they say in the north, "a wee bit too cannie" for those who hoped to find in him "a flat" ready made to their hands. He left, vowing he would never go to a fair again: he probably will though, and as probably will get what he wants. He showed them, at all events, he was too wide awake to be talked into taking what he did not want-a flat-catcher.

Now we cannot speak in as favourable terms of our young friend who had the stud. He had gat 
everything he did not want, and nothing that he did. He wanted the horses at the time he bought them, most certainly, and found sellers quite ready to accommodate him; but this only eventually brought about another want: he wanted to get rid of them. How this was accomplished we have shown.

But the friend who acted the friendly part in recommending the stud to be got rid of by the most summary process, only considered his young friend's interest in so doing. He little anticipated the mess he was getting into himself, for he did not at all see that getting rid of a lot of useless animals involved the being hooked in for subsequently buying a better sort-a job that (guessing the thoughts and feelings of the man from what we have seen of him) was above all others the least to his taste.

He was, however, perfectly satisfied, or rather assured on this point, by his servant interrupting him, in the midst of his breakfast and the perusal of an interesting article in Tre FreLD, by putting into his hand the following short but too explicit note :- 
"Dear Aidme,-I am quite convinced you showed your good sense and judgment in advising me to sell my former stud, and equally showed your prompt. ness of action in the way you managed their sale. The kind and friendly feelings that then actuated you, will, I am sure, induce you to procure me a few horses of a better sort, as you know so perfectly what I want.

"Yours ever,

"Fredertck Aufred Suppliast."

"Confound the fellow!" said the one thus addressed, "how should I know what he wants? So, because I good-naturedly get rid of a parcel of brutes for a mere acquaintance, I am to be lugged into doing what is at all times an arduous office, even for friends. Perhaps he thinks he pays me a compliment in doing this." He chucks the note to the furthest corner of the breakfast-table, taking up The Fredd again.

Having finished the article he was interrupted in the reading of, and his breakfast at the same time, 
his countenance resumed its usual bland expression, and he proved the little ebullition of his ruffed temper lad passed off, by his exclaiming to himself, in allusion to the article he had read-'Clever fellow that! I should like to know him. I could give no instructions or advice to him: he wants no 'light from any man's candle.',"

We infer this to have happened early in the week. "I suppose," says our friend, "I must call on this young devil: writing wonld be quite out of the question, as I must then unequirocally declare my intention of complying with his request, or refusing to do so,-neither of them exactly pleasant alternatives."

A day or two afterwards, he determined to see his somewhat troublesome young friend. Now, if he confessed the truth to himself, he was in hopes that when he saw him he would suggest one of two different modes some people have of making use, or, at least, attempting to make use, of their friends-in which case he could decline the distinction of being thus treated, and, consequently, would be enabled to 
rid himself of the business altogether. The two ways in which he conceired the youngster would propose making use of him were these : either to be lugged about to all sorts of places that his conductor might choose to take him to, though as unlikely to find what was wanted in them as if we searched Saunders' fair-booth in expectation of finding a composition of Mozart's there. The other likely proposition (he thought) would be, that the young one would go himself, finding a lot of animals that no one would look at twice, and then favour his friend by trotting him off to look at them, making it a point that those that lie had seen and were most approved of by him should claim his friend's first attention. We need scarcely say the old one was too wide awake to be made use of in this manner, if, as he supposed probable, it should be proposed.

He called on his young acquaintance at the somewhat unusual hour of half-past eleven, and found him breaking his fast by having laid a foundation of one, or part of one, of Fortnum and Mason's Yorkshire pies, that came to table set off by their orna- 
mental outsides, and was polishing off with a part of the contents of a tin of sardines.

"I suppose," said our friend entering, "you young gentlemen of fashion and late hours will hold this an unheard-of time for a morning visit, as I was once reproached for calling and insisting on seeing one of you, on business of importance to him, by being told I had 'disturbed him in the middle of the night:' it was then about this hour."

"Delighted to see you!" exclaimed young Suppliant. "You got my note?-but have you breakfasted ?"

"I breakfasted," replied his friend, "some three hours ago, and got your note two days since. Now what do you want me to do?"

"Well then," said our young friend, "I want you to aid me in getting some horses. I want you to tell or show me the sort I ought to purchase; how many are necessary for what I want them to do ; and, further, the price it will be necessary for me to give." "Anything else?" said our friend, with a goodhumoured smile on his face. 
"Yes," replied our hero. "I have not half done with you yet, though perhaps you may determine to have done with me, seeing the exorbitancy of my demands on your patience and good offices."

"Well, supposing I make no such determination, what remains behind?"

"Well, having got the horses, I want your ad. vice as regards their treatment; and you will not say I am very self-sufficient when $I$ ask you to instal yourself my tutor as regards my using them. In fact, I want lessons from you on the score of not only treating horses, but in riding them."

Our experienced friend found that all hopes of shaking off his young acquaintance had vanished. Who could refuse assistance and advice to one who asked it so modestly? He found that all the bad taste that he had seen exhibited arose from misconceptions of what was good taste; he found his young friend had sense enough to perceive that it was so: and, further, he had the far rarer merit of allowing he had been in error. Here was something to work 
upon; here was sense and good intent as hostages for his after-conduct.

Now, had he found himself expected to aid and abet a repetition of his young friend's former follies, he would have cut the thing at once, and have left hin to make as great a simpleton of himself as he wished; but the case was altered. He now found a sensible young man, willing-nay, wishing-to be led the right way; so he determined to serve him to the best of his own judgment and experience.

"Well," cried Mentor, "what do you propose by keeping horses-in other words, what are the pursuits in which you mean to use them? We can then decide on the kind of horse required."

"Why, I mean to hunt this winter."

"There can be no reason you should not," replied Mentor; but somehow it struck him his young friend's peculiarities must be a good deal altered before he could make any figure (unless a bad one) by the cover side. However, he said nothing.

"Why I particularly wanted to see you was this: there are six of Mr. ___ s horses advertised for sale 
at Tattersall's, on Monday. Now, if you are at leisure to-morrow (Sunday), we could go and have a quiet look at them, and any we particularly liked we could see out early on Monday morning, and then return in time to buy them."

"My young friend," said Mentor, "you have good sense, and I have no reason to doubt your having an equal share of good temper. You will, therefore, not take anything I may say ill, even should it not be complimentary to your judgment in horse affairs. I know the horses you allude to, know the owner of them, and, further, know him to be as fine a horseman as ever crossed country. I know that illness alone causes his horses being disposed of, and other people know it too. Have you made up your mind to gire three or four hundred a-piece, or perhaps more, for these horses?"'

"I can't say that I have," says Pupil (looking somewhat aghast at the price named) ; "but why do you infer they will fetch such unheard-of prices? They are not race-horses?"”

"No they are not: but they are worth more, and 
will bring more than many horses you see going as race-horses, aye, and winning too. We will talk of such horses at some other time, but will confine ourselves at present to $\mathrm{Mr}$._—'s horses. You ask why I infer they will fetch such unheard-of prices. You mistake the thing: such prices are not unheard-of. Hunters have been sold at double the price I have named: but why I talk of three or four hundred being about the likely price, is this-"

"Excuse my interrupting you; but I think I have heard you say that frequently a horse or two was to be bought out of a stud at a moderate price, from his not having. suited the country he had been hunted in, though he might be even a brilliant performer when taken to another."

"I have said so; and I perceive by the smile on your face you think you have caught me on the hip, or, in other words, contradicting myself; but I will explain. In most large studs, where from perhaps fifteen to twenty horses are sold, what I have stated as to be expected is pretty certain to be the case. A very large number of horses is not easily got together, 
all equally suiting a country; but Mr. - did not keep a large stud; he has but six, and two of those you see he calls hacks."

"Of course," said the young friend, jealous of his dignity as an embryo sportsman, "I did not allude to the hacks when I expressed a wish for one, or two, or more of Mr. - - 's horses."

"I perceive you do not quite understand the thing," says Mentor; "Mr. _- has six horses, four of which he calls hunters, the other two hacks. As he always hunts in the same country, he takes care that his horses suit that country; and further, that they are as fine, good, and perfect hunters as giving long prices, and afterwards riding tliem as few men could do, can make them. The two lie calls hacks are perhaps, excepting his other four, as perfect hunters as a man could reasonably wish; and, hacks as he pleases to term them, you will find they will go close to two hundred a-piece. There are few things so good but a better in some particulars is to be found-his hecks are only excelled by his hunters." 
"But," says the young one, perfectly astonished, " is it not lowering his horses in other persons' estimation to call them hacks?"

"Not a bit; they are as well known as his hunters, and their merits will be appreciated, call them what he will : nor will they, as you will see, be overlooked, because the other four may be a shade more perfect."

"But what does he promise himself by calling them hacks, when, as you say, they are rery superior hunters?"”

"I can only infer he does it from sheer affectation, a bit of pardonable, but we will not say commendable, vanity. He knows the two he calls hacks are such hunters as the generality of men do not possess, and he is aware they know so too. He knows the term will not influene the price, so he indulges in this bit of affectation, well aware he will lose nothing by it as to price. But I will give you a specimen of men's vanity in two instances among a liundred that I have seen :-Some years since, I was waiting at a cover-side that the hounds were drawing; a very spicy gentleman was there also. We naturally spoke, and our 
horses were discussed. I complimented him on the condition of his. 'Tolerable,' he lisped. 'And I infer from it,' said I, ' that he is a good hunter.' 'Oh no,' drawled my new acquaintance; 'I do not call him half a hunter-I seldom ride him.' I cocked up my ears at this, and ventured to inquire in what particular as a hunter he failed, asked if he was slow, or a bad fencer? 'Oh, no,' said the gentleman; ' he is fast enough, and can leap anything; but the brute rushes at his fences.' I detected a particularly thin glove on my gentleman's hand, bordering on kid ; from this and his mode of speaking $I$ at once 'spotted' my man. 'I mean to sell him,' continued this jonquille (the term 'pink' is old) of a sportsman ; ' he might suit some people.' I humbly submitted that I might be one of 'the people' he might suit; so said, if the horse, in consequence of the failing specified, was to be had at a moderate price, I might buy him. 'Oh, yes,' lisped the gentleman, 'I shall sell him at little money-a hundred and fifty.' Determined to pay off the jonquille in his own coin, I said: 'I am afraid he must rush 
very objectionably, from the lowness of the price you require; I seldom get anything that can carry me as I wish, under four hundred. Good morning.' The other instance of fastidious vanity was shown by an acquaintance of mine, who piqued himself on his collection of pictures. He showed me with great and just pride a Domenichino, certainly a magnificent specimen of the master-he had given fifteen hundred for it; a Rubens, with his fair, and in point of flesh, somewhat redundant beauties-this had cost him a similar sum; then came a Claude, with one of his matchless sun-risings-this had cost also a heavy sum. After looking at these almost matchless specimens, I saw a small picture hung behind the door. I was struck by the grouping of it, and made a remark to that effect. 'Yes,' said he, 'it is a pretty little furniture picture.' I saw it going at Phillips' for fifty, and foolishly bought it ; but it has no business here. I shall move it to my dressing-room, where I have several of the same stamp; they save repapering the room.' You see there is affectation in other things besides horses; men show it in different ways. 
Mr. - - shows it in calling two of his horses hacks."

"Then," said young Suppliant, "you consider these hunters quite beyond my pretensions and purse ?"

"I in no way pretend to judge of the extent of the latter, neither do I wish to disparage your pretensions; but you will excuse me in saying that, for your first season, I consider it would be lavishing uselessly your money, to purchase horses of that class. You will pardon my bluntness, if I say it would be useless to bestow a set of highly-finished tools on a man, till he liad learned how to use them."

"I quite understand you," said the pupil, with perfect good humour, and laughing: "you mean that a hedge-carpenter would spoil the tools."

"I in no way mean you are the hedge-carpenter," replied Mentor, in turn smiling. "I only mean you are beginning your apprenticeship, and doubt not your soon becoming a finished workman."

"Well then," said Pupil, "since you consider the 
hunters would be thrown away on one who is not a finished workman, what do you say to the hacks?"

"I am afraid I shall at once lose your good opinion when I say the same by them. This is your debut in the hunting field, and I consider it quite unnecessary that you should give two hundred apiece for horses to carry you. For this reason-I suppose you do not contemplate making that débût in any of our crack countries. You will find just as much amusement in others; for let me tell you the leading cause of a vast number of men hunting in the first is again 'affectation,' in another form. Half of them care little for the hunting. Most of them are men of large fortume; they can afford to have all-butfaultless horses, and they go into countries where the pace hounds go, and the nature of such country, enables them to show they have such horses. I have there heard, when a check occurred, many a man anathematise the fox, hounds, and huntsman, while at the same time I could see from the state of his horse that three or four pastures more would (at the pace the hounds had been going) have brought 
his nag to a fixture: here is another little specimen of affectation for you."

"This does not seem in character with the usual idea of a sportsman," said Suppliant.

"Granted; but all men who ride the best of horses, all crack riders, and, between ourselves, all Leicestershire men are not sportsmen, though they enjoy the prestige of being so. Ask Osbaldeston if I am far astray in saying so."

"Then where," modestly said the young one with a smile, "would you recommend the great undertaking of my début to be commenced ?"

"I should recommend you, for a season at least, to hunt in Surrey, Hertfordshire, or Essex; in fact, I should advise your hunting in each. The first will teach you the best way of getting up and down hills; the second will teach you to be attentive to hounds; for unless you are, you will find them slip off with a fox, and here are no pastures of a hundred acres succeeding each other, so as to enable you to see hounds though they may be a mile ahead, and induce you to try the very, very uncertain feat of catching them. 
Here are no gorse covers, from whence, if a fox breaks, he is sure to be tally-ho'd. Here you must give an attentive ear to what hounds are doing, for sight will avail you little. Such is Hertfordshire, or at least great part of it; it is not, however, a bad school for a beginner. Now we come to Essex : this is no country for young sportsmen, or any sportsmen on thorough-breds, to sail away, taking everything flying, and in their swing. Here you will find blind fences that require great patience in man and horse to get over safely. Neither of the countries I have mentioned are at all to my individual taste ; but they are each of them a good school for a beginner."

"Or," remarked Pupil, "for a hedge-carpenter."

"No, but for an apprentice," replied Mentor: "and advising you to try them is the reason I said 'even Mr. - - 's hacks would not be required, nor in either of the counties I have named are such horses wanting. Hounds cannot go the pace they do in flying countries; not but that possibly the hounds may in themselves be as fast, or nearly so, but the nature of the country stops them-luckily for those 
who ride with them, for did it not, as it would comparatively stop the horsemen, the hounds would have it all to themselves."

"But, according to your own account, what with hills in one country, the being obliged to be near hounds in the other, and the blind fences you speak of in the third, a horse ought to be a very clever hunter to be able to carry one in all of them."

"If," said Mentor, "you had studied for a week, you could not have found a more applicable and expressive title than 'a clever hunter.' Such is precisely the kind of horse I should recommend to you; one that (you will excuse my saying so) will, to a certain extent, teach you to cross a country instead of your having to teach him. But being very clever only in a very limited way shows superiority, and by no means promises the extraordinary attributes of Mr. _-'s horses, or others of the same known celebrity, as regards fencing, speed, and lasting powers. Give me ten five or six-year old horses, I will answer for it in two months I make eight out of the ten what may be fairly termed clever hunters." 
"But why," inquired the Pupil, "not say the whole ten?"

"Because I cannot give capability where no capability exists. Some horses have no springy powers in them. I have met with two such in my life; they were fine young five-year-old horses, by their looks promising to make hunters. I bought them, thinking to make them such; but found out in one fortnight they had no more elastic or springy powers in them than they would have had had their limbs been made of lead. I sold them for harness, and, being fine horses, got the money back I had given for them-I think about a hundred and seventy the two."

"Probably," remarked Pupil, "this may be the reason why we see so many horses going in harness that we might think were by nature intended for hunters."

"In very many instances this may be the case, but not so often as you might suppose. There is a certain kind of horse bred expressly with a view to sell- 
ing them for harness, and, as hunters, the breeders may justly, in racing phrase, warrant them ' untried.'

But we have had a tolerably long chat for one sitting; we will speak more about hunters when next we meet." 


\section{CONCERNING THE STUD.}

"I STATED in my last conversation that I would, with (we will say) eight out of ten horses, render them perfect hunters in two months; I do not retract a syllable of this. Let me, however, be perfectly understood. I only mean I would make them perfect so far as nature had given them the powers of becoming so. A horse may be very clever, and very perfect, yet not possess the capability of one far less desirable as a hunter. Moonraker jumped (I think) thirty-two feet; but it is not in any shape necessary a horse should be capable of similar exertion to be as good a hunter as can be ridden. I will venture to say we never meet with a fence in a run with fox- 
hounds that would require such exertion to compass. It is true we occasionally (but very rarely) meet with a fence that from the first impediment to the last may be (we will say) twenty feet; but then such fences are mostly to be done by a double jump. The horse that would attempt to do such a fence at one would possibly break his back, or his neck; even if extraordinary power enabled him to do it while perfectly fresh, he would not do it after a moderate burst. This makes such horses dangerous. They are safe enough while their extraordinary powers last; but, unless they are properly taught at first, or learn by a multitude of falls in the course of a season, they know of no reso urce when those powers fail."

Tyro listened attentively to what had been said, but then remarked pertinently enough: "But horses never would learn the resource you speak of, in their progress towards becoming hunters, as they would never feel their powers fail from exhaustion."

"Your observation is quite correct; but I will, I think, answer it by a simile. If we show a man how to make his exit from a house by the door-way in 
preference to the second-floor window, and habituate him to do this, it is not necessary to make him try the latter experiment at the risk of his neck to induce him to use the more common and easy mode of exit. We teach him the most convenient way out, and, having learnt this, depend on it he will adopt it. So we teach the horse to do what he would find he must do, if his powers had failed; and, it being the easiest and safest mode of taking large fences, he from habit has recourse to it before necessity compels him to do so from distress."

"I am answered," replied the pupil; "but do you think that in your private tuition you could have all the fences prepared ready, that a horse might encounter when crossing a country."

"I certainly could not muster each individual fence that he may be destined to meet with during his life, or, at all events, his hunting career; but, mutatis mutandis, all he could reasonably be expected to meet with would so much resemble those I should accustom him to take, that they could all be done in the same manner. Brooks so closely resemble each 
other, that, with the exception of width, they all are the same. Timber is timber, meet it where you may, with the exception of how and where it is placed; and a man must be a simpleton, or at least a very young hand, who would put a horse at a stiff gate so placed that it would be next to impossible that he could clear it."

"But do you think a horse would face what it appeared impossible for him clear?"

"That would depend very much on circumstances. A very young and high-couraged horse, excited by hounds and other horses, probably would do so; a horse accustomed to be ridden by'a thoughtless, inconsiderate, reckless rider would perhaps do so from fear. The judgment of the animal as to the danger or possibility of the thing would possibly be better than that of his 'Bull rider ;' but he would prefer the danger of hurt by a probable fall to the certainty of being punished for refusing. I am quite willing to admit that refusing his fences is about as bad a fault as a hunter can have, with the exception of having no jumping capability in him, if he tries; 'but the 
latter,' as a dealer once said of a blind or brokenwinded horse, 'would be his misfortune, not his fault.' But if a horse has all the requisites of jumping at command, his refusing (for the time) renders hin next to worthless, whether it arises from stubbornness or timidity-from whichever cause it proceeds he must be broke of it, though by diametrically opposite means. If, which would not be the case with one horse in fifty, his wilfulness or his timidity could not be cured, the only trade for him is 'leather.' "

"But you have not answered my query as to whether you could find for private practice fences of sufficient variety to qualify a horse to take all such as he might meet with in a day's hunting."

"As to what he might meet with," replied Mentor, smiling, "I am free to confess he might meet with things for which I could not prepare him. What say you to a train of artillery going along a road he was preparing to cross? But for all he would be at all likely to meet, I will be bound I would so prepare him that he should neither refuse nor be at a loss how to take it." 
"But," said Pupil, laughing, "you bar the train of artillery."

" "Name it not in Gath," " quoth Mentor; " but, though I can see no reasonable chance of his meeting with a train of artillery waggons dragging their slow length along, he might meet with what I certainly should never have dreamt of practising him at -namely, a waggon laden with corn, and drawn by a team of four horses."

"Why," remarked Pupil, "I should think no one would attempt or could practise a horse at what no horse has ever attempted to clear, or could have done if he had."

"That no horse in his proper senses would attempt to jump it, or any sane man ride at it, I am quite willing to admit; but let me tell you it has been done by a horse perfectly under the control of his senses; nor has his master and rider, which was myself, ever been threatened with coercion on the score of insanity."

"It was lucky for you; for it strikes me nothing 
but madness at the moment wouid have permitted a man to even make the attempt."

"I did not make the attempt, knowing the odd kind of feat I had undertaken; but, as you shall hear, there was no desperation in it, though it sounds like it in the mentioning. Hounds were running very hard, I a little wide of them, and perhaps a hundred yards or so in their rear. I saw them all top a fence, and disappear. I of course inferred it was a drop leap, with a pretty wide ditch on the other side, which

* they could not clear, so had jumped into it. I put on the steam, trusting to clear the whole. To my dismay, on reaching the fence, I found it inclosed a lane, with another fence on the landing side, and, to my perfect astonishment, just in the place I was riding at was the waggon before alluded to, laden with sacks of corn. To stop a somewhat free-pulling horse, going nearly top speed, would be next to impossible; so I did the other thing, gave him an accelerator, and a real Irish shout, and he landed safely, crashing the opposite hedge, which was lower than the one on the taking off side by several feet, which 
accounts for my not seeing it till close on the leap. The waggon and team, being in the bottom of the lane, of course did not make the leap one atom more difficult, and altogether I should say it was not twelve feet from the one fence to the other. It was nevertheless a queerish jump, and though nothing in any way uncommon as to height or width, was uncommon in itself, and one that a less courageous horse would probably have made some dangerous boggle at."

"But," said the pupil, "you must allow your horse did not face the waggon and horses from any instructions he had had in private practice."

"Decidedly not; nor did he clear two fences ten or twelve feet apart from any instruction; but he had been practised at so many double fences that he knew as well as I did how to take them. For instance, if there was only six or seven feet between the two fences, he would probably, nay, certainly, take them both in his swing; if the distance much exceeded this, he would as certainly, if there was any foothold, go, as it is termed, 'in and out,' from knowing 
from practice it was safer, and saved himself the strong exertion which clearing the whole involves. But a horse properly taught and practised knows perfectly well, by the way he is ridden at a fence, whether he may use his own instinct as to the mode of taking it, or whether he is to be guided by the judgment and will of his rider. If ridden a fair moderate pace at it, he will (for in such case he is able to do it) either go in and out, or take it in his stride. If he is ridden hard at it, and feels the knees of his rider press his sides, the pace will, perhaps, prevent his doing it at twice; for the impetus would probably prevent his temporary landing on the bank between to enable him to make, as it were, a second jump. Now, my horse in the waggon-jumping feat took both fences in his swing. He had two very cogent reasons for doing so: in the first place, he was ridden at it at a pace he could not have stopped had he wished to have done so; in the next, he of course saw no place to make an intermediate landing-place of, unless he had fixed on the sacks in the waggon for that purpose ; and again, a stroke of the whip and my halloo 
(things unusual with me) somewhat astonished him."

"Then you do not approve of a halloo, or Irish shout, as you have termed it, to horses?"

"I am convinced, constantly used, it is a very bad practice; and though I have the highest respect for my good friends the Irish as regards their riding, as I have for their very many conspicuously good qualities I have found them possess, on this point we are at issue; and I am quite sure, if they err in this particular, it arises from what influences them wherever they do err in other cases, namely, excitement and want of reflection. The frequently shouting to a horse produces at last the same effect as we read in ' Esop's Fables' did the boy's constantly crying out 'The wolf! the wolf!'-it is at last unattended to as a signal that unusual exertion is required; and, if omitted, the horse jumps or not, as he feels inclined. It should be kept in reserve for particular occasions." "Then, of course, you as much disapprove of the whip and spur being used?"

"To their frequent use I most decidedly object 
'with both my hands.' In the first place, by the constant use of them we cause every leap to be more or less an occasion of punishment to the horse. Consequently he naturally gets to dislike it, and it is only the fear of greater punishment if he refuses, induces him to jump at all. It is cruel ; it is more than cruel. Men who make a practice of it, if they had the sense of reflection or the common feclings of humanity about them, would see that it virtually amounts to this : they punish a horse if he leaps, and severely punish him if he does not. Nothing can be so brutal or absurd. I grant I have found the necessity of using both whip and spur on a sudden emergency, but I very reluctantly did so on a good horse. But I unhesitatingly state, what to some persons will more avail than would any advocacy on humanity or kinduess, I am quite convinced the frequent use of whip or spur to a horse, so far from insuring his doing the leap safely, has a diametrically opposite effect; he grows to be influenced more by the fear of punishment and shrinking from it than he is by the fear of falling. Experienced horsemen know wcll enough it 
is to the horse's fear of a fall, and knowing his business, we are mainly indebted for our safety. We want him to use all the instinct, or selise, or whatever it may be called, in measuring his leap, and to use all the practical acts he has been taught, to do it in the safest way. It is, therefore, all but an act of insanity to cause the dread of punishment to interfere with this exertion of instinct; we, in fact, drive all attention to what he has been practically taught out of his head-for we will suppose even instinct emanates from the brain. The unthinking votaries of this 'bull-riding' may say 'Pooh pooh, nonsense ! I don't want the horse to use his instinct or knowledge ; I only want him to make exertion; I will decide where he is to take off, and so forth.' This is all very fine; but, good sir, you cannot decide where he 'is to take off, and so forth.' He must, after all, take off when he can and where he can; and if you, by your bull-riding, do force him to take off at the moment you wish, and not at the time he ought, or if not frightened would have probably done, if he comes down, who is to blame? It will be found to 
be the case that all men, with a few exceptions, where anything is done and another is accessary to its accomplishment, endeavour to take all the credit of the act to themselves, and wish it to be thought that it is to their sagacity its being well done is owing; but in case of failure, they, liberally and magnanimously, are quite willing to throw all the blame of failure on any other party concerned in it. They even carry this into the hunting field: if an uncommon leap has been taken, they wish it to be thought it was by the joint effect of their head, hands, and heels it was accomplished; if they come down a regular burster, they attribute it to some unavoidable cause, or to "the brute of a horse." "

"But," remarked Pupil, " 1 have heard men enlogise their horses very much-affirm such a horse to be remarkably clever-state that another had carried them a season or two without giving them a fall."

"You have heard sensible men do this who are just enough to give the horse credit for the cleverness and capability he possesses." 
"But," persevered the other, "I have heard all sorts of men boast of the goodness of their horses."

"Doubtless you have; but, let me tell you, many of these mean the praise to be understood in about the same way in which a workman praises his tools. The carpenter may say, 'This is a capital chisel ;' the engraver, 'This is a capital graver ;' but, depend on it, both workmen mean the merit to be attributed chiefly to their being perfectly masters of their business, be that hunting, carpentering, or engraving."

"But does not thus underrating the tools lower their estimated value in the eyes of other people?"

"Not a bit. Such superior workmen as these are (or pretend to be), will tell you they never use any but the best and most valuable tools that are to be found; and a great value they put on them, as you would find if you attempted to become a purchaser. But, with such superior tools to work with, they still wish it to be thonght it is their own superior handicraft that produces the work so much to be admired. Remember, I am not alluding to sensible men and good sportsmen, but to the many young, conceited, 
self-sufficient, arrogant men of large means, who scarcely know which to be most vain of-themselves or their fortunes."

"From what I have heard of them, I should say you have been alluding to Leicestershire men."

"Perhaps my mind did 'hark back' to something of the kind that I have seen there. But recollect that when you meet with the greatest number of superior workmen, it must be expected you will meet with a somewhat unusual number of conceited ones; and where you meet an assemblage of men of large fortune, it as naturally follows you must meet with many vain of their position. Speaking generally, there is nowhere to be met a finer set of fellowsmore finished gentlemen or courteous men-than are to be found at Melton, Leicester, and the neighbourhood. But their conspicuous situations as to fortume, and the consequent largeness of their hunting establishments, renders any affectation or arrogance, perceived in some, conspicuous in proportion.-But I have been led into talking about men, instead of sticking to the subject we were upon." 
"Which was the constant use of the whip and spur ; also the shouting to horses at their leaps."

"The application of the whip and spur I had quite done with; and I am quite sure on every account it would be well if riders in the field had done with it also. With regard to the shouting-an unfortunate expression I made use of, and which you do not seem disposed to forget-it is, perhaps, too strong a term for the act; but many men, and fine horsemen, have some favourite term they use to their horse at his leaps-such as, 'Come up!' 'Go along !' This they so constantly use, that they are unconscious when they do it; and, let me deferentially tell them, their horse at last becomes unconscious of it too. So every effect from it ceases, and then cui bono?"

"Is this practised in what you term our crack counties ?" .

"I will reply to you by analogy, which I think will answer your question. When I lived in Ireland, the high road ran within a hundred yards of my house. Now I must tell you that the Irish coachnen, to speak generally, were, in point of neatness of 
coachmanship, some half century behind the Eughsh artistes. The Irish coachmen have, or had, a habit of constantly urging on their horses in the intervals of using the whip, by calling out, 'Hup, hup!' and I assure you I do not exaggerate when I say that, when the wind set the right way, I could hear the 'Hup, hup' of old Denny, a coachman on that road, a good quarter of a mile before his coach came up. Travelling per coach in Wales, I found a somewhat curious specimen of a Knight of the Toeboard. He had a most extraordinary and monotonous sound, (for I know not by what other name to call it), which he constantly grunted forth for the acceleration of his team, who took as much notice of it as they would have done had he treated them with 'God save the Queen.' Whether they would have stopped altogether had the accustomed ejaculation ceased, I cannot say. He called it 'spiriting 'em up a bit ;' but his thong, that fell like a flail, seemed to me the only effective accelerator. There was a time, I believe, when coachmen of the first class used the voice a good deal to their horses; but not since I noticed 
such things. The finished coachmen of the Pearl, Age, Manchester Express, Berkeley Hunt, \&c., held it miserably slow to say a word to their teams, unless it was to quiet them, or preparatory to a pull-up; the double thong drawn gently across a wheeler, or the point lighting like a fly on a leader under the swing-bar, was enough for such teams as they drove. I leave you to judge by this, whether on such horses as first-rate workmen in the field ride, they would not hold it infra dignitate to use an expedient sometimes resorted to by a whip on a tired horse."

"Then, I suppose," said Pupil, "I should be held a Goth by these highflyers, if they knew I had even asked the question."

"Not at all," said Mentor ; " the voice often stands in better stead than whip or spur; in a case of sudden emergency it is quicker in its effect. It is only its frequent use I disapprove, knowing that by it it loses all effect, like the Welsh coachman's sepulchral appeal to his horses."

"But the whip and spur do not lose their severity by frequent use." 
"They do not altogether do so," said Mentor; "but, as I before said, their frequent use so alarms a timid, or even free horse, that he becomes confused, and loses his self-possession, while the sluggish one, who learns to bear both without flinching, I should say was unfit for a gentleman to ride." 


\section{ERRORS AS REGARD THE STUD.}

"Do you recollect," observed Pupil, on meeting his friend, "the request contained in my note of a week or two back? If I remember right, it was asking for the advantage of your judgment in getting what horses you think would best answer my purpose, the number that I should want, and then some advice on the riding and treating them."

"And you mean," said his friend, smiling, "that I have somewhat reversed the order of things by making remarks before any horses are purchased. I plead guilty to the charge, but have been led into doing this, first, from not wishing you to suppose that (in advising you not to purchase Mr. - - s horses) 
I meant that you should be content with decidedly inferior animals; and to prevent your being under the influence of such error, I have been led into describing different countries and different men, and to show you that horses for which a very large sum would be expected, though possessing peculiar qualifications necessary in some countries, would not do what you would require of them in others one atom better, pleasanter, or more safely, than such I hope to get for you at a moderate expenditure. But we will go to work as soobn as you please. Have you heard of any thing likely to answer our purpose on sale?"

"Why, I think I have. I understand that, from some cause or other, _- is giving up steeple-chasing, and that some three or four of his horses will be sold. Now it strikes me that horses that have gone in steeple-chases in various counties must be so practised that all sorts of fences must be A B C to them. They must be fast horses, and they must be good ones, or they could never win. There may be certain drawbacks in them, in point of slight blemishes or appearance, that very fastidious men might object to, 
but which I expect you to say I must put up with, not intending to give long prices."

"Allow me to ask you two questions, to each of which I anticipate the same answer. Did you ever ride a steeple-chase, or have you ever been on the back of a steeple-chase horse on any occasion? I will conclude the question answered. Now I have done both (though I never rode in a public steeple-chase at a recognised place for such sports), and liave seen a good deal of it-both in England and Ireland, Now steeple-chase horses, if of a superior class, and sound enough for the purpose, will bring their six or seven hundred, even supposing in point of look they might be ill-looking enough to cause them not to be worth twenty pounds, wanting their peculiar qualifications."

"Pardon my interrupting; but you said, "if they were sound enough for the purpose.' What did you mean by that?"

"I meant there are particular kinds of unsoundness that would very little (if at all) interfere with the attributes of a steeple-chase horse, and having 
which, he would still command a high price as an animal to win money with, which is usually the sole object of the steeple-chaser. A chronic lameness might render the riding such a horse a slow pace on a road an act of positive danger ; but once set a-going across country, he is as safe, as far as relates to the effects of the ailment, as a cat on a carpet. It is known that with this ailment, if the horse is kept off the hard roads, it will probably be stationary, that is to say, it will be neither better nor worse, for perhaps three or four seasons; quite time enough to enable a horse, if a good one, to be the means of putting a large sum in his owner's pocket. But, on the other hand, the slightest indication of a sinew going is fatal. It is bad enough in a hunter; but in a horse that runs for money, he becomes all but worthless for such purpose. It is true he may go for the stakes; if the leg lasts, probably he wins; if it goes, he is a cripple for life. Whichever way it turns out, all confidence in him is gone, no matter what the odds : his owner, who would back his capabilities for hundreds, is afraid to back him with his infirmity for a farthing. This 
explains what I meant by saying ' if sound enough for the purpose.'",

"You asked me," said Pupil, " if I had ever ridden a steeple-chase, being at the same time perfectly aware that I had not; but you also asked me if on any occasion I had been on the back of a steeple-chase horse. What, was your reason for asking that question ?"

"I will tell you. If you had been, and had ridden him at a fence or two, I infer you would have been no little astonished. There are some steeple-chase horses that are pleasant to ride. Lottery was one. He was a remarkably good-tempered horse. Vivian was quite the reverse. He had what is technically called but one side to his mouth; and the Captain (that is) Beecher, has told me, that knowing him even as he did, he sometimes hardly knew whether he would clear the leap, or trust to breasting it and boring through it. He was a large, strong, and commanding horse, and seldom fell; but when he did, it was a cropper. Steeple-chase horses are accustomed to go at their leaps at three-quarters speed; and many 
of them, unless permitted to do so, will make a mess of it. In fact, there are many that do not at all leave to the option of the rider the pace he wishes to go. Many on starting will rush to the front; no man can stop them; and probably, if they are effectually checked, they turn sulky, and will not jump at all."

"I must say your description of steeple-chase horses does not at all accord with my premising that, from being accustomed to go in many different counties, they must be more or less perfect jumpers in all."

"It is impossible they can be so. There can be no doubt but that a stake and ether hedge, as in some countries it is called-that is, a hedge something like a wattled hurdle, placed on a bank, making the leap five feet high, with a ditch say five feet wide-would be the same, meet with it where you would, and horses would of course take it, meet it where they might; but it is blind and intricate fences that occasion the number of falls we see and hear of in hunting. I will venture to say that where one fall occurs in taking a fair, big, rattling jump, ten occur at fences 
that a good pony could compass, and would carry us safely over : these kind of fences rarely occur in the line of a steeple-chase course, where those who mark it out take care (not having to ride over it themselves) that the fences shall at all events be big enough. It is greatly to the safety of steeple-chase riders that this is done, for though smaller, if blind fences were in the line the casualties would be awful. Thus you see that horses' going in steeple-chases in different. counties does not bring them to the knowledge and cleverness we want in the hunter, their chief practice being at large fences, and their chief merit a certain turn of speed to finish a close race, a qualification not requisite in the hunter. There can be no doubt but that a tractable, good-tempered steeple-chase horse would be in a straight-forward country, where the leaps are large, and do not occur often enough to tease him, a superior hunter; but these horses are not accustomed to be checked, to take some fences in a slow canter, others in a trot, and again, some in a stand. They might in time, if not irritable, be brought to this; but then the result would be, they 
would be spoiled as steeple-chasers, and would be no better than many other horses as hunters."

"I feel I am answered in this particular, but I do not think you can gainsay what I have stated as regards their goodness; they must be undeniably good horses."

"About as undeniably good as is the horse that can run a mile in an unusually short time. $\mathrm{He}$ is good for that particular purpose, but as an animal he may be good for nothing else. Beeswing, Catherina, Doctor Syntax, old Isaac, were all really intrinsically good animals ; they were good "at all games," as the saying is, though each better at certain weights and distances than at others. The race-horse (that is a particular horse) is superior for a mile; his 'bolt is then shot ;' if you wanted him to run two miles and a half, you might run the last mile yourself; for, figuratively speaking, he could not do it much faster. Now we will give the steeple-chase horse credit for being good for four miles. He may be able to do this in about twelve minutes - a great pace certainly, when we take into consideration variety of ground and ex- 
hausting leaps; but we frequently have a burst with hounds longer than this, and we should not much admire a hunter who would come to a standstill soon after he had carried us four miles. I do not mean to insinuate that the steeple-chase horse would do this; the probability is that he would not. I only mean to say, in answer to your idea that steeple-chase horses must be good animals, that their going four miles in a quick time is not irrefragable proof that they would be good hunters in a long distressing rum with foxhounds. Making what we will admit to be wonderful exertion for four miles, and for the brief space of at most a quarter of an hour, is quite a distinct attribute from the endurance wanted in the hunter for the long distances, and prolonged time. A burst from some of the gorse covers in Leicestershire, though not altogether as fast as a steeple-chase, approaches so near it at times, that if four miles found out the soft place in a steeple-chase horse, depend on it five in a flying county would find it out also; and you are to recollect that, provided he had won his race of four miles, his owner would not care one 
farthing if from the exertion he was at death's door, provided Mr. Death did not insist on his walking in. He has plenty of time to recover himself between the past exertion and the forthcoming one. But our comfort, and let me hope humanity, would forbid us bringing our hunter to such state after a burst, and it is not every man who can afford to have a second horse out every day he meets hounds."

"Steeple-chase horses are sinking fast in my estimation; from your remarks on them they are now, to use an anti-sporting term, below par with me, when thinking of them as hunters."

"Do them not so much injustice; all I have said only goes so far as to show that the conviction you entertained that their going as steeple-racers was proof of their having the requisites of a hunter, is a mistake. Lottery, who I have named, had all the requisites of one, and Vivian, in point of goodness, would have gone the longest burst ever known with fox-hounds. Little Brunette, the Irish mare, was as good as gold, and many I could mention were horses both pleasant to ride, and of sterling merit as hunters. But, re- 
member, such horses are not come-at-able; their peculiar capability has been found out, and while they are able to bring it forward they will be kept to their trade."

"I have had steeple-chase horses shown me," said Pupil, "that appeared to me to be in no way up to the weights such horses usually carry. How is this?"

"In the commencement of steeple-chasing, which was as a known sport, I should say, five-and-thirty years ago, gentlemen made up a purse or stakes to be run for by the fastest of their hunters, from point to point, or from the starting-place to fixed points, to be run to and then home; each man went as he liked, provided he rounded these given points. This very soon went out of vogue, and flags were introduced, to the left or right of which (as the case might be) each rider was compelled to go. Twelve stone was the accustomed weight each horse had to carry. If any man had a little slight animal that might carry him, riding say nine stone, of course the weight shut him out of the race, and very properly so. 
Steeple-chases were then intended for fine horses, and the amusement and encouragement of men who owned such. But this did not suit certain cliques, who were determined to have a finger in the pie that was made for other and better uses. The weights were lowered; this let in a vast number of horses not hunters, but thorongh-breds, who would not, perhaps, pay for training as race-horses, but, being practised at jumping, took their places as steepleracers. This was all very well at first-it produced what was called sport, that is, it let in a number of all-but-worthless animals to contend for the prize originally intended for fine horses; but it has not stopped here. There might be some justice in letting in a good horse, not, perhaps, up to twelve stone, but who would make a very good fight of it with eleven. But even this would not do. So now some weedy wretch is handicapped with nine stone, and possibly wins a stake ten, fifteen, or sometimes twenty times the value of the animal, against a horse that would not be sold for the amount of the 'take up.' It is true the owner risks the amount of the 
entrance, be it what it may ; but he only risks breaking down thirty or forty pounds against another owner of a horse risking perhaps four or five hundred. All this produces betting-that is, if any man can (as steeple-chasing has been long carried on) be foolish enough (not to risk, for he has not the advantage of risk to console himself with) but-to stake his money where the way it goes is made a certainty. This has completely lowered steeple-chasing in the estimation of every sportsman. It is no longer the pursuit of gentlemen, or, collectively speaking, of any but a set no man of honour would wish to mix with."

"You have put me as much out of humour with steeple-chasing as you have with steeple-chase horses," said Pupil. "I shall eschew both for the future."

"There can be no possible occasion that you should eschew either. I should not object to start a horse to-morrow for a steeple-chase, if I had one possessing the required attributes; but there are two other unfortunate ifs not so easily managed as getting the 
horse, but very necessary provisoes, which are-IF I could keep my horse under one of Chubb's locks, and IF I could keep the rider in a similar safe situation, unless he was a man-of which it would be invidious to say there are not some-on whom I conld depend."

"But," said Pupil, laughing, "you might be beat after all; for we know that Chubb's locks have been picked."

"They have; but, to carry on the metaphor of keeping horse and jockey thus incased, Chubb's locks are detectors; and, on finding they had been tried, I should be quite awake to the game that had been going on. I am now alluding to steeple-chases at recognised steeple-chase meetings, not of steeplechases at a time when, for a very brief period, they were chiefly the pursuit of gentlemen who liked a little excitement of this sort."

"Do you consider horses suffer a great deal in going a steeple-race?"

"Not so much as many persons imagine. We can call forth no great exertions from either horse or 
man, without causing some suffering. Perhaps a mile race causes the least; it is an effort that lasts two minutes, perhaps less ; and it is more wind that is completely 'pumped out,' and want of speed, than anything else that loses such races. I have seen a hundred and twenty yards run by men at a pace that even in this short distance they have been winded. Half a minute after, the pipes are all right and in tune again ; it is the same in short races. In longer races or steeple-chases, the distance is greater, but the horse is trained accordingly, so as, in training phrase, to 'get the length into him ;' and I am quite certain many hunters suffer much more (when not properly prepared) in a fair burst with fox-hounds than do steeple-chase horses in a four-mile course. There is another great disadvantage under which the hunter labours - he is sometimes ridden by an injudicious, unfeeling, or what I shall term a 'show-off rider ;' in either case he suffers. Now the steeplechase horse is very rarely, if ever, subject to such treatment. His rider is, in most cases, a good horseman-a good judge of pace; he feels at once (from 
practice) when his horse is distressed, and he 'pulls him off.' I do not mean, of course, that steeplechase riders are more celebrated for humanity than hunting riders; but he is put on a machine with which (supposing he intends winning if he can) he manages as does the driver of the locomotive-he keeps back steam enough to carry him home. He must not, or at all events ought not, to do anything for a show-off. His riding is a business, and must be done artistically to be done well. The greatest piece of affectation I ever saw in a public rider was starting with a lighted cigar in his mouth, I suppose to show his sang froid. Of course the bit of puppyism was laughed at by every sensible man, but it was like the man, and characteristic of his usual bearing."

"I suppose he won, after such a display of pretended nonchalance?"

"Whether he won or not I am not prepared to say, but he did not win his race, though he possibly might his money. But you made a remark that $I$ have in no way replied to. You said words to the 
effect 'that you have been shown steeple-chase horses that struck you as not indicating by their appearance the capability of carrying the weight allotted them.' Your remark was perfectly well founded: many do not appear so qualified; and it is astonishing how some slight horses will and do carry twelve stone (a tolerable steadier, we must admit, for anything like racing) : but remember, when we judge of a horse's powers as to carrying weight, we usually allude to what he is likely to be master of for a day's hunting, not what game, high breeding, and resolution may enable him to live under for a quarter of an hour. Extra exertion will enable many a highlybred horse to go, and jump, with such a weight on him, for the time a steeple-chase lasts, who would be tired to death after sustaining the same weight for two hours together, though not called on for the same exertion a race involves. While the powers are fresh, elasticity, and the capability of (to use a new word) superequine exertions, will last; but so soon as such freshness is passed, horse or man are prostrate. Men, in exhibiting feats of strength, will 
support two half-hundreds on their little fingers for, perhaps, a minute or so; but they could not sustain half the weight for a lengthened time; so it is as regards horses carrying weight.-There is another thing that causes a vast difference in horses being able to go under weight for which they do not appear calculated-this is the style or manner of their going. A horse that, with good loins and strong quarters, brings his haunches well under him, and is what, in technical phrase, we call somewhat of a ' round goer,' will often carry, with ease to himself, a weight that another horse, stronger in general appearance, but who extends himself too much in his gallop, could not live under. And again, people are sometimes a little hasty or injudicious in their judgment; they often cast a cursory look at a horse, and say he has not bone enough. They, in short, judge a good deal of his strength by his legs. Now, we all know that a certain proportion of bone is not only desirable, but necessary; but I have on various occasions, when persons have remarked that some horses I have had appeared deficient in bone, said, 'Just grasp his 
leg, will you ;' they have found it a handful. People not very conversant with such matters are often much deceived by the size of a good flat leg. In coarser bred horses there is a portion of flesh on their legs, in the high bred one there is none-it is all, figuratively speaking, iron and wire. You may laugh, which I see you do, at my expression; but this I can tell you, the bone and sinew of the thorough-bred horse is so totally different in texture from that of the commonbred animal, that the size of the latter is far more than counterbalanced by the quality of the former." 


\section{HORSES CUTTING.}

THE correspondent of the FIELD, who has flattered me by requesting my opinion and advice as regards this most objectionable habit in horses in general, and his own horse in particular, must be kind enough to bear in mind that cutting or striking their leg's proceeds from such various causes that to attempt to point out a preventive in a particular case, the cause that produces the habit must first be known. More futile still would be the attempt to point out a preventive to cutting, that would answer the intended purpose as regards all horses.

I will, however, to the best of my ability, point out such causes and effects as have been brought under 
my notice, and the remedies that experience has proved to me to be the most effectual.

Cutting the legs arises from malformation, faulty action, sometimes from unequal proportion, sometimes from indolence; and, per contra, I have known instances where it has arisen from impetuosity. Horses weak from illness are very apt to cut if used before their strength is restored. It is almost unnecessary to add, that tired horses very commonly cut or strike their legs, though they do neither under other circumstances.

No man, I should think, would purchase a horse bearing evident marks of being in the habit of cutting, or of having been so, unless he could feel certain of being able to ascertain the cause of his having done sô, and that cause being of a nature not likely to occur again; but, even under such circumstances, he stands in a very equivocal light, in our estimation, as showing he has a propensity to a failing that a slight deviation from ordinary circumstances may produce again. In a general way, I should personally reject a horse showing indications of cutting, however I 
might like him in other respects. Let it be observed, I only speak in general terms : under particular circumstances I might be induced to vary in my decision.

A man might purchase a young horse of a dealer, showing legs free from any mark whatever of having been cut or hit, yet find, on bringing such horse into work, that he cut awfully; nor does it follow such work need be of any peculiar severity or continuance; for people should bear in mind that ordinary usage is more or less severe work to an animal unaccustomed to any, save what he may have undergone in the process of breaking.

In purchasing a young horse, or, indeed, any horse, the first thing is to notice whether there is any peculiarity of form likely to be prejudicial to him in his work, keeping in mind that cutting is as likely to be so as any fault he can well possess. Stand before and behind him, and mark well the way his legs stand in a quiescent state; even by this a tolerably certain inference may be drawn of what will be their direction when in motion. I have frequently seen young horses, of whom I liave said - " That horse must interfere if 
put to work" (I need scarcely say "interfering" is a technical term for cutting); in others the form has, perhaps, been so faulty, that I have remarked in stronger terms, "That horse would cut his legs off wheu he came to work," without pretending to particular perspicuity in this particular-any man, with moderate judgment, might have foretold the samething with equal certainty.

I will instance the giraffe. Any common observer will remark, if this animal attempted to gallop with the ordinary action of the horse, his hind legs must overreach his fore ones. The animal is aware of this, or habit or instinct teach him; so he brings his hind legs outside of his fore ones, and in his gallop they actually show before them. It is thus with the way in which some horses' legs are put on ; as I have expressed it, "They must cut," unless they had a peculiar style of going, to do away with the effects of their unusual form; and this it will not be found they possess.

Horses that turn their toes much out are very apt to cut; and horses with their ankles much in, the same. 
I have seen horses with their ankles very close together, who did not in any way interfere in any pace; but when this is the case, it will be found on inspection their feet stand perfectly straight : close as the joints may be together, there is still space for the foot to pass when thus rightly directed, without striking the supporting ankle.

Horses with" their toes pointing in, seldom cut, though we might anticipate they would do so; when they do, it is usually in a fast pace. They will then, as it is termed, "cut speedy."

The next thing to be attended to, as regards cutting, is the horse's action. If he goes near the ground, so that the uplifted foot does not rise higher than the ankle of the stationary one, ten to one he will cut. Again, if his fore legs are unduly long, they are apt to produce a dwelling sort of action that will cause him to strike the inside of the leg above the ancle.

Indolence, producing a lazy style of going, frequently causes horses permitted to go in such a way as to cut their legs severely; this is to be easily proved when it is the case. In technical phrase, "catch 
hold of his head," that is, take up the curb bit ; clap your legs to his sides, or, if that is not sufficient, touch him with the spurs; make him trot alertly ten miles an hour, instead of six lazily. He will cease cutting; it produces a different style of action and a different motion of the legs. This shows the difference between mere instinct and reason; the latter would teach the horse that by going in a certain way he cut his legs and hurt himself; he would voluntarily alter his mode of going. Instinct does not go thus far; consequently, we must use our reason, and cause him to do it.

A friend of my father's had a very nice horse, a good goer, and one who never touched a stone on the road, yet sometimes would make a drop, as if one of his legs was broken. Trotting him along over some level turf one day, he did so, and down he came. It was considered unaccountable. I begged to see him out, and, standing before him, had him trotted towards me. I saw at once that he passed the lifted leg within the eighth of an inch of the resting one just under the knee. The matter was explained at once. 
He at times hit the standing leg so hard with the passing one, that the pain caused him so far to yield the hitten leg as to produce the drop mentioned. He did not hit with the shoe, consequently made no mark or blemish; but, from a peculiar twist of the passing leg, he hit the other with his hoof. I suggested a plan of shoeing him that effectually prevented his doing this, which I will mention among other devices for curing cutting, or, at worst, palliating its effects.

Want of space prevents my doing so in this article ; but it shall form the subject of my next, with remarks on the best kind of boots for the same purpose.

Cutting is the term usually applied to horses striking their legs; but be it remarked, all horses who strike or hit their legs do not cut; but they frequently strike the quiescent leg, whichever it may be, so hard as to produce bruises, and consequent inflammation to a degree that is really worse than a clean light cut which wounds, and scars the slin only. Horses with large flat feet, if they hit, invariably (I may say) hit with their shoe, and that only, and the 
HORSES CUTTING.

shoe cuts; but if, on the contrary, they have high upright mule-like feet, they frequently hit with some part of the hoof, and bruise without absolutely cutting.

It is sometimes very difficult to decide with what part of the hoof or shoe the horse strikes the standing leg-that is, it is difficult to judge by the sight only ; but it is to be accurately ascertained by a very simple and short process.

Take the horse into some clean place- $a$ hard dry road is the best; smear his hoof and shoe with a little white paint if the legs are black, with black paint if of any other colour ; cause him to be walked for a quarter of an hour; if he has struck, or even brushed either leg, the paint will be disturbed or wiped off from the precise part he hits with, and it will further show (in cases where he does not actually cut) the spot he hits, for on it the paint rubbed off the other leg will be visible. If during his walk the paint remains undisturbed, we may fairly infer it is not in that pace he hits his legs. Trot him; if he hits, you will see where the offending leg has struck, 
and where the struck one is hit. As in his walk, if the paint remains as it was put on, we must infer it is in his canter or gallop that the collision takes place. Having ascertained this most indispensable fact, we must then endeavour to prevent it, or, at least, palliate its effects.

People attach a far greater degree of inevitable danger and likelihood to horses coming down from cutting than (objectionable as the failing is) is absolutely the case. When the horse cuts or hits his leg, the pain occasioned by it causes him to wince, falter, and, indeed, I have seen a horse go a step or two after the occurrence, absolutely on three legs; but the fear of falling is greater than the pain of the hit leg, and he mostly saves himself. This is when he cuts or hits his ankle only. But if he hits just below the inside of the knee, which he never does but in a quick pace, he will then sometimes come down as if he was shot. This is appropriately called "speedy cutting"-the worst and most dangerous failing among all cutting, and one that is incurable. For this reason: it proceeds from a particular direc- 
tion of the offending leg when in action, which not once in a hundred cases can be altered. We have no resource but defending the part hit by a proper boot or legging for this express purpose, a most inconvenient and unsightly thing at best, and, moreover, all but certain to gall and chafe the leg to which it is applied. I should say, put the horse to a description of work where the pace in which he is apt to cut is not required.

Cutting or hitting the hind legs is, of course, far less objectionable than the same failing as regards the fore ones, not alone from its not subjecting the rider to danger, but the hind parts being lighter than the fore ones, we can take greater liberties with the hind legs as regards shoeing, and can throw them by such means more out of their natural position than we can the fore ones, and still interfere but little with the horse's power, action, or safety.

Horses are decidedly more apt to cut behind than before when in harness, and vice versâ when under the saddle. This I consider, arises from the tension being greater on the hind legs when in harness, and 
the weight being thrown more on the fore ones when carrying a rider.

Much may be done towards preventing cutting by judicious shoeing. But let not the reader deceire himself by being too sanguine in his anticipations on this head. We may, and can, in many cases effectually prevent a horse cutting by bevelled shoes; but this is not always to be trusted to. We only prevent by this the sharp edge of the shoe coming in contact with the standing leg, which would otherwise be wounded by it. There are many horses that would still hit if they had no shoes on them, and if we could cut half the hoof away, would cut still. It is the position in which the standing leg is placed by nature, and the direction of the moving or passing leg, that produces the failing. We cannot alter nature; we can only bring art to remedy to a certain degree the natural defect.

I mentioned in my last article a horse that came down from striking his leg when going on level turf. The plan by which I remedied this is, I believe, but little known. Smiths are very apt, on being told or 
seeing that a horse cuts, to shoe him, as it is termed, "thick-heeled" on the inside, or to make his shoe altogether thicker on the inside than the out. They tell you that by this mode they turn or twist the ankle further out of the way of the passing leg. They do ; but they are not aware that if they do remove the ankle of the standing leg-say an inch further out of the way - they bring by this method the passing leg three inches nearer the standing one. To show the effect of this, let any one place a bit of wood an. inch thick under the inside of the tread of his shoe; if he does this by the right foot, he will find his body thrown out of equilibrium to the right. Let him in this position attempt to pass his left leg by the other - he will find it inclined to touch the standing leg; now let him remore the piece of wood, and place it under his right foot on the outside of his tread-he will find, though it may bring his ankle nearer the left leg, that leg in passing will be some inches away from it. His body is thrown out of equilibrium to the left; the left leg follows the body and, try as 
he will, he will find he cannot bring it in passing close to the right standing leg.

I had the horse alluded to shod with a shoe thick on the outside. I did not by this remove the standing leg further out of the way, but I gave the passing one a direction far away from the one it formerly struck. It succeeded, and I superintended the shoeing three or four other horses that cut in the same way, with similar beneficial results. I am happy to say they were not mine.

I do not anticipate this plan might answer as regards the hind legs (though I never tried it), but I judge by this-it is easy to turn or twist the hind ankles of the horse out of the way; but it would be difficult, if not impossible, to throw the body out of its equilibrium by anything we could do by the hinder parts ; and it is by doing this the effect I have mentioned is to be produced.

I promised to mention something relative to boots in this article. I do so; but, while there are so many clever men who make them for racehorses, I shall do much better for my readers in recommend- 
ing them to such persons than by giving any opinion of my own on the subject. This advice I will, however, venture to give-which is, not to buy a horse who must wear one when used; and if you have one, sell him-he is a constant plague.

Racehorses are so valuable that it would be unwise to risk their taking their gallops, and still more so their sweats, without boots; but such as they wear are too unsightly for common use, though a light leather guard on a hind leg may be used on a favourite having the failing of cutting; but no boot can be made fit to use in ordinary circumstances, combining sightly appearance with efficacy and comfort to the horse. The India-rubber boot held out promise of being all that could be wished. So it was when first put on; but if used in summer in hot weather, it became so soft as to be useless, and in winter the cold so contracted the substance it was made of, that all elasticity was lost, and it became harder than common leather. The only useful bont is one made of kersey, and strong leather placed outside, where the horse hits. These may be made a little more 
sightly by being of strong thick cloth, the colour on the horse's leg, in lieu of the ordinary kersey.

One of the great objections to the usual preventives to a horse wounding his legs is the not being able to keep them stationary. If they are put on tight enough to effect this, their tension on any joint to a certain degree impedes its pliability; if left more loose, they get out of place, and chafe by friction and the dirt getting between the straps that fasten them and the leg. These straps are usually made simply of leather. I always had them lined with kersey; it makes them softer, but the lining has a greater advantage-not, like the leather, being slippery, it keeps its hold better than a smoother surface. Boots such as racehorses wear are easily kept in their place, being made of kersey, and only stiff leather put on inside ; the straps and buckles outside (the leg being flat) prevent them moving. But guards for the ankles are a great plague; the joint is round, and it must be evident to firmly fix anything on a round of any kind is very difficult; hence, the chief motive I had for lining the leather straps. $\Upsilon_{t}$ is almost needless to 
HORSES COTTING.

say guards must be made with reference to the part likely to be injured.

I have seen but little improvement in boots and cutting guards since I was a boy. I have seen a vast improvement in the breed of horses, in point of formation and action, and it is hard if a man under such circumstances cannot select horses that in ordinary use require neither boots nor guards to prevent him cutting his legs. 


\section{B OXES FOR HORSES.}

THere can be no doubt but that every building for the stabling of horses should have boxes attached to it, the number, of course, varying in accordance with the number of stalls. No hunters' stable is, in fact, complete without them. I have had occasion twice to build a hunters' stable for my own use. I built them (or I should rather say, in one instance I altered a barn into a stable) with stalls for four horses, and a box at each end for two more, which I think is a useful proportion of stalls and boxes. The latter had two entrances-one from the stable, the other from the yard. The entrance to a box (where there is but one) should invariably be by a door cut 
transversely-the top door to lift off at the hinges, and, where there is a side door, the rack and manger should be on the same side as the door opens. For the uninitiated in horse matters, I will state why such particulars should be attended to.

The door opening into the yard should be cut in half and take off at the hinges, in order to admit air when we wish it in the case of a sick horse, or, in summer, of a healthy one; and an iron door or gate should in such case substitute the close one. In all and every case the doors of a box should open from the outside, for it may not strike the casual reader that, where this is not the case, a sick horse might fall or lay himself so close to the door on the inside that we could by no means get access to him but by breaking down the door. When there is a side door this might not be the case; but even then, unless the box is very large, it is quite possible a loorse might lie in such a situation as to bar entrance to him if both doors opened inwards. In summer time it will be found a great source of comfort to a horse if the iron gate is covered on the outside with canvas to 
keep out the flies - a constant torment to any horse, but more especially a sick one.

The reason I recommend the rack and manger being on the same side as the entrance-door (where there is a side one) is this : horses will be found almost invariably, when feeding, to stand obliquely in their box, that is, with their heads to rack and manger, their hind quarters pointing towards the opposite side. Thus, if we place the rack and manger on the opposite side to that by which we enter, unless the box is large, we get the full benefit of their heels as we enter; a circumstance by no means desirable with some horses, more especially when feeding.

Corner racks and mangers are greatly to be preferred to those that run the entire width of the box; they take up less room; and with the others the horse occasionally turus his tail to the manger, and, when standing in such position, soils it.

Boxes for racehorses are usually larger than those made for the accommodation of other horses. This is done with an eye to the time when they inhabit 
them when out of training, and are made thus with a view of affording them the means of taking a certain degree of exercise by walking, trotting, or, as they sometimes will do, actually cantering round them; for the frolics of a racehorse when idle are extraordinary. Boxes made for hunters or other horses, are, I should say, sufficiently large if made (say) seventeen feet by eight or nine. This size, if properly ventilated, affords all the air and comfort a healthy horse requires.

A box is a great source of comfort to a horse after a day's hunting; he can lie in any position that he may find gives the greatest ease to his wearied limbs; and if put in one the night before hunting, it ensures him repose undisturbed by other horses or persons. This opportunity of stretching out his limbs is not required in a general way by horses; for though, after a day's hard hunting, a horse may, at times, be found lying on his side, with his legs stretched ont at full length, he must be very tired, or very ill, to have recourse (pro tempore) to such position; for the rotundity of a horse's ribs are such as to render 
it painful to lie on his side for any length of time together. A horse in good health, under ordinary circumstances, will rarely, if ever, be detected in such position, and for his ordinary mode of resting himself, a good wide stall is ample space.

Having said thus much for the formation and structure of boxes, and having stated under what circumstances they are required, let us now see how far they are to be recommended, or the reverse, for general use.

Every person at all conversant with the habits and dispositions of horses is quite aware that they are social animals; therefore, though being alone and undisturbed is solacing to them at times, it becomes irksome, and, in fact, a punishment, if continued for a length of time. The "knuckering" or neighing which a horse makes, and the uneasiness he shows, on his companions leaving him, and the satisfaction he manifests on their return, prove this.

Let a horse be confined to a box with the upper part of the door made of iron, so that he can watch passing objects, or be on the look-out for them. You 
will find him, at most times, when not actually feeding, with his nose close to the bars. If the top door is quite open (supposing he can be trusted with it so), he will be found half the day with his head and neck thrust out of it, watching what is going forward. That they do this is quite clear, and are amused by it.

It may be alleged that racehorses live constantly in boxes, and do well in them. But it is quite futile the comparing them with other horses. They are bred, treated, and used, in a way peculiar to their caste. A racehorse, unless it is a gelding or mare, must be kept in a box. He is used to it from a colt, and his very nature is changed by treatment. Instead of missing his fellows or hailing the sight of them with pleasure, in very many instances he cannot be allowed to approach them; he is, in fact, in such case a domesticated wild beast, kept for the purpose of running for money. I do not mean that he is actually ferce natura-he is no more so by nature than any other horse; but he is rendered so by the way he is brought up, and consequently the 
desire for companionship is lost to him, and he does not feel the deprivation.

I am quite clear that horses (in technical phrase) "do better" in stalls than boxes, unless those boxes are made with rails only between the inhabitant of them and the other horses. Whatever cheers the spirits must be beneficial to horse or man, and vice versâ. Horses feed better from hearing others eat; and many a horse that would not touch a feed of corn, given to him in solitary confinement, will set to work himself, hearing others grinding.

A good deal may be said in favour of keeping valuable horses in boxes on this head; they permit them the privilege of standing or lying down, as they like. There is no danger of their getting cast or of getting loose ; in which case, though horses are, as I have said, social animals, the intrusion into the stall of another horse by a loose one frequently throws a whole stable into confusion, and often produces the direst catastrophes. But let me correct the term applied. I have used that of boxes; better to say, where stalls are not used, compartments for horses. 
These should be made boarded up at least seven feet near the racks and mangers, for say three feet from the wall, and five feet high the remaining part of each side, with this precaution, that the rails are too close to admit a horse's nose between them; and they should be made of iron. A convenient space for walking should be left behind these compartmentssay five feet, better and handsomer; six or more wide. The railing behind may be of wood or iron, and wide enough to see the horses conveniently. I need scarce say the compartment door must open outwards, and be made so as to fall back close on the other railing, for the safety of horses coming in and out. To those who have plenty of room, and do not mind expense, this plan may be adopted if desired; but I must say I consider it in no way a necessary one. The stable I have mentioned, with a proportion of two boxes to four stalls, I hold to be quite adequate to the comfort and wcll-doing of horses.

The getting cast is easily guarded against by an invention that any saddler will procure for the purpose ; and the getting loose is prevented by the safety head 
collar, which the saddler will also supply; by using which your groom must be a very ignorant or careless fellow if a horse gets loose.

Double head collar shanks or reins look more stylish than a single one, I admit; but I prefer the latter, which answers every purpose, if put a proper length. Some horses have a trick of scratching their heads with their hind foot. In this case I consider the double shank more likely by far to catch the foot than the single one. Now I believe I have stated all I know "pro and con" the use of boxes. 
Arma virurnque cano.

In making a few remarks on this subject, a most im portant one to the safety and comfort of the rider, I must prelude the doing so, by saying that a vast deal of this safety and comfort are, to use a figurativeexpression, "literally in the rider's own hands." As well might I expect to make a trip to the Nore in safety and pleasantly in a vessel under my own direction, as a man to ride with a prospect of either if he has bad hands. We use the term "hands" only from habit; but it must be evident that at times the arms are also called on to act in unison with the hands. 
Were a man with such to ask me what kind of bit I should recommend his using, I should indubitably not consider what sort of bit would suit the horse's mouth, but the one that would suit the man's hands. By this I mean, I should not recommend the sort of bit that would suit the horse if ridden by a man with good hands, but the kind with which he would be the least punished and confused, ridden by a man with, as we technically say, "no hands at all." The bridle with which, in the first case, he would go pleasantly and gracefully, would, in the latter, become neither more or less than an instrument of torture, under the effects of which he could go neither pleasantly, gracefully, or even safely to himself or rider.

One would naturally suppose that any man in the habit of riding would be anxious to acquire so necessary a part of liorsemanship as good hands. Daily observation, however, shows that it is not so; and this inattention or indifference arises from various causes. The first is, the man knows nothing about hands, consequently does not know that he has bad 
ones; again, if he does know this, as he merely rides an animal for health and exercise, and having found one who has no more mouth than his master has hands, the latter has probably found himself safely enough carried, and wants no more.

There are two specimens of this sort of rider that I will particularise. The one is a gentleman I frequently see riding up Constitution Hill, sometimes with a lady. He mostly is seen in a good long trot, his body obliquely on his horse, his bridle-arm and left shoulder forward, and his right arm working like the piston of a steam-engine, his whole person more or less acted on by the working of his right propeller. Could mortal teach this man hands? The horse he rides is so used to have his mouth lugged at, that doubtless it is a matter of indifference to him what sort of bridle he has in it, and his master probably thinks, as regards effect, all bridles are alike. It would be cruelty to both horse and man to give this gentleman a fine-mouthed animal to ride, or a bridle that would make impression on the mouth of the horse he uses 
The next specimen is a gentleman who works both legs as energetically as the other does his right arm. So, as far as his legs are concerned, he works away as strenuously as if he was running seven miles an hour. This, I suppose, he calls horse exercise ; it is far better-it combines the exercise of the pedestrian with the quicker progression of the horse he rides. The gentleman leans a good deal forward, his bridlehand resting on his horse's withers, or rather neck. By what word, signal, or talismanic touch he stops or guides his horse, I know not, but certainly not with the bridle.

How are such men to know how far, or how much, they vary from others? They have probably hitherto got on safely, and have got to the place they wanted to go to ; they have no large looking-glass to show them the grotesque figures they cut in the eyes of other persons ; and no one will tell them of it. And supposing they did, it would be thought they greatly exaggerated the thing. They would give lasting offence without producing even incipient good.

A vast deal of the badness of hands arises from 
badness of seat. No man can have a fine or delicate hand on his horse unless his seat is firm and steady. As well might a watchmaker attempt to set a watch while seated in an American rocking-chair in full motion.

As the subject of this article is not one of my own choosing, but is written at the suggestion of another, I must be excused if $I$ treat more on hands than bridles-my object being to show that they will neutralise the effects of the most appropriate bit, while at the same time they would ruin the finest mouth.

I should say I could mention at least twenty different sorts of bridles, all, or most of them, good for certain horses; but if I did, cui bono! The horseman knows them as well as I do; he also knows the kind of mouth each would suit. The man who is not a horseman would be no wiser from my mentioning Chifney's jointed mouth-pieces, gag-snaffles, \&c.-names he never heard of ; and their uses he of course cannot understand. The man with bad hands could not make use of such bridles, consequently he 
would be no better off from the being informed there were such.

If a man pays my judgment the compliment of asking what description of bridle I would recommend for a horse that throws his head up, I could not expect he would say: "I have what you would call 'no hands,' consequently my horse, to aroid the punishment of the bit, my hands, such as they are, occasion him, throws up his head." Such, however, I suspect, would be about the fair way of stating the case.

Supposing he was candid enough to state this, I should first inquire, has your horse a good mouth, that is, a tender one, which, from his throwing up his head, I suspect is the case? Is his mouth, temper, and disposition such that a curb-bit can be dispensed with? If it is, ride your horse by all means in a plain snaffle and martingal (not a nose one). If he requires a curb, use an easy one, and only make use of it occasionally. I would strongly recommend all men with bad hands to use martingals; not exactly to keep the horse's head down, but 
to counteract the effect of their hands getting $u p$, which is nearly always the practice with bad riders, unless, indeed, in the case I have mentioned, of the gentleman who keeps his hand on the horse's withers, I recommend martingals, because with one it matters little where the hands are; they cannot affect the horse's mouth so far as respects the elevating or lowering of the head. All they can do is to use such force in pulling the reins that the horse cannot (and I should say would show his good sense if he refused to) advance. Probably the rider would take such "hint direct," and moderate his pull at the reins.

Hands may be considered the refinement of horsemanship, without which no man has any pretensions to the character of a horseman; he may ride boldly, and may sit fast; this he would learn, if as a boy, he had been kicked a few times off a jackass. This does not make him a horseman. The difference between riders, I hold to be-the one sits on the back of a horse, crossing a country in such form and style as 
the animal likes; the other causes the horse to do the same thing, but in a proper manner.

Good hands are to a man of fortune worth a diadem to him; in virtue of them, he is carried as no man wanting them can be. It may be said his money could purchase horses that want no hands to make them do their business handsomely. He might; but if they wanted no hands to make them go in such manner, still less do they want bad ones to thwart tham when they do.

They are invaluable to the poorer man ; they enable him to purchase horses hitherto thought little of from a bad style of carriage, and raise the price of the same horse, while in his possession, from, perhaps, eighty to a hundred and fifty.

I will particularise a specimen of fine hands in the person of an individual everybody in the horse-world knows-Rice, as he is familiarly termed, Mr. Anderson' 8 (of Piccadilly) right-hand and second self. His hands are worth, I should say, 500l. a year to his em. ployer, for this reason - any man of fortune wanting 
a horse to carry him pleasantly, has only to go to Anderson's, and there he will be sure to find him. All the horses have been ridden by Rice; he knows what a gentleman expects in a horse; rides them like a gentleman himself, and does so till they are perfect, or as near perfection as fine hands can make them.

Finally, hands are of the utmost importance to the horse himself, particularly in hunting, wanting them, beats many a good liorse before his time. Permitting a horse, in technical phrase, to " make a spread eagle of himself," and go sprawling along over a deep fallor, "sews him up" at once. It is quite a fallacious idea to suppose that a horse knows the easiest way of going to himself. He, perhaps, would do so in a state of nature ; but nature is not crossing a hundredacre holding pasture, with twelve (or more) stone weight on his back.

Huntsmen sometimes have not good hands, particularly in very inclosed countries; their attention is too much taken up by their hounds, to permit them to attend as much as they otherwise probably would 
to this particular in riding. Their horses, consequently, in the course of time, learn to take care of themselves. Perhaps a man accustomed to the treadmill learns the same thing, but this does not teach him a handsome style of walking; few huntsmen's horses are pleasant ones to carry a gentleman; and, in sooth, some gentlemen with bad hands teach their horses a style of going not pleasant to any one but their owners. 


\section{BRIDLES.}

I SAID in my last article on the importance 0 hands as respects the comfort, and sometimes indeed safety of a rider, that I would not specify the different kinds of bridles that may be used on horses, stating as my reason that horsemen know them all, and their several uses, quite as well as myself; and again, men unacquainted with such matters would not know how to use a bridle, or rather bit, so as to make it answer its intended purpose. On after thought it strikes me there are men who are neither so au fait of the subject as to render observation useless, or so much the reverse that any hints given them 
would be also useless, from not knowing how to apply them. There is a middle class of riders, of which the majority of those who ride are mainly composed: in medio tutissimus ibis I conclude is their motto, and in this way it certainly holds good. They would not get a broken leg from backing their horse against an omnibus, and as probably they would never ride at a gate or brook; they run no risk of getting a fall from the one or a souse in the other; yet such riders know quite enough to be aware of when their horse goes handsomely and pleasantly to themselves, so I infer that to such a few hints on bits may be useful. It will be sufficient if I give the names of them and their several uses and effects; their form may be seen by going to a bit maker.

First in point of severity comes the Chifney; the great merit, indeed, the only effective peculiarity it has, is, acting at once on the horse's mouth untrammelled by the check-straps of the bridle, which its double upper branch enables it to do. It has another advantage, it returns to its place instantlv on 
the hand relaxing its stress on the rein. It is for a hard and heavy-headed horse a most efficacious bit in efficacious hands, if used with a bridoon. And here let me make one observation, that is to be regarded as a rule without an exception, but in one case which I will mention in its place. No curb-bit should be used without a bridoon that is snaffle-bit also.

Next comes the ordinary double bridle, or, in other phrase, "bit and bridoon;" in this case the bit is made to be more or less severe, according with the horse's mouth it is intended for. And here I must enter a little into the form of bits. In the first place, a good deal of the more or less severity of the bit depends on the port: a high and wide port, giving ample room for the tongue, admits the bit to come down on the bars of the horse's mouth; a less elevated port resting on the tongue, of course, keeps it away from them, and with such a bit the only appui we have is the curb-chain.

Sadulers, or indeed bit-makers (unless very scientific men) make one great mistake in bits. They Q 2 
will give you a bit with longer or shorter branches, as they are (I think very improperly) called, in accordance with what you may represent your horse's mouth to be. This is all right enough, as far as it goes, giving you a longer lever to act upon; but they seem to forget it is only the lower branch, that is, the one below the mouthipiece, that is the real lever; the upper branch, to which the curb chain is put on, only acts so far as, by preventing the upper branch moving forward, it brings the mouthpiece in immediate contact with the bars of the animal's mouthas a plank of wood, if confined at one end, then placed orer (for instance) a gate-post laid down, would on being pressed on the other end, act with great force on the gatepost laid under it as a fulcrum or balance to the plank. Now it is quite evident, if we shorten or lengthen the part of the plank on which we press down, we diminish or increase the force of the pressure; the other end fastened down would, in fact, lessen the power of the lever if lengthened.

It is precisely the same with a bit: the upper 
branch acts as the part of the plank fastened down; the bars of the horse's mouth represents the gate-post laid down as the fulcrum or balance; and the lower branch of the bit as that part of the plank we press on-in fact, the lever.

By this, I trust, it will be seen that it is the force of lever we get by the length of the lower branch of the bit that causes its severity. The enormous bits we frequently see (and did see formerly far more than now) in the mouths of carriage-horses are preposterous; they defeat the purpose for which they are designed. By making the upper branch so high (or long) the lower one is obliged to be made of unusual length, to correspond. Let them cut off an inch or two from the length of the upper branch, the bit would become more severe. The length only carries the curb-chain higher up the jaw, without producing any good thereby.

It is with many objected that a short upper branch permits the bit (as it is called) "to draw under the chin," that is, to draw too obliquely in the horse's mouth; it would do so if the curb was left the same 
length as with a longer upper branch; but shorten it, and the bit will be found to remain as horizontal as you please to have it. All the very ancient bits have or had the upper branch particularly short, the lower as particularly long. By this they became most powerful engines in the horse's mouth.

Having thus endeavoured to show the principle on which all curb-bits act, the reader is left to select such a one as in point of force is suited to the mouth of the horse for whom he wants one.

I will next mention the jointed or Turkish bit, as it was called when first produced. This is the only curb-bit without exception, in the use of which we may dispense with a bridoon and second rein. It is jointed in the mouthpiece, and the cheeks or branches are moveable; by this the force, as applied to the horse's mouth, varies as he moves his head; and on relaxing our stress, and then resuming it, we in commou parlance "get fresh hold," that is, the pressure is changed by the moveable nature, or rather make, of the bit, on resuming our pressure on the mouth. This is the reason why I say it is the only bit fit to 
be used without a second rein. With any other, however severe, the horse's mouth becomes callous, or", in more technical term, "dead," from the pressure always coming on the same part of it ; we may relax," but cannot change the pressure. A man with such a bit finds after a time the horse goes "heavy in hand ;" he takes up his curb-chain a link or two. For a time, by thus increasing the severity, he finds his horse go more pleasantly, that is, "lighter in hand;" but in an hour the effect is lost-the mouth again becomes callous-and so it would, ad infinitum, if he had a vice in his mouth, if the pressure was always on the same part.

Next comes the Pelham. This is a bit with the mouthpiece of a perfect plain or twisted snaffle, to which are added two side-pieces or branches, like the ordinary curb, and like that, is used with a curb-chain. Of the utility of this bit much may be said for and against. It is one I should not recommend to a man with a heavy hand, or for a horse with a heavy head; but, at the same time, it is a most useful one in the hands of a horseman for a horse whose mouth is too 
tender for a curb, and yet wants a something at times more effective than a plain snaffle. It is by no means a bridle with which the curb-rein is to be constantly in use; for in that case its effect would be lost, as there is no bit on which a horse will sooner learn to lean or " hang," as it is termed. It is only to be resorted to at times, and then let fall again. Having but one bit in the mouth, fretful horses will sometimes go quietly in a Pelham when they would be irritated by a double bridle; for horses with very light mouths who are apt to throw up their heads it is most useful, in good hands, and particularly serviceable as an adjunct to be used at times. It has one great advantage over the bridoon of the double bridle. It is, when used as such, a complete and direct snaffle, which the bridoon is not. It is not hampered by the curb-chain passing under it, and by the curb-bit interfering with its free action, both which circumstances worry and fret a very irritable horse.

I intended to have finished my category of bits in this article, but find I have only half completed my work; I shall, therefore, leave the remainder as a 
subject for a future one. In the interim let me give a hint to my readers that to some may be usefulthe saddler has plenty of business in his own line, and plenty of scope to show his ingenuity or superiority, but, ne sutor-go to a bit-maker for bits. The saddler only buys them; the latter makes them, and further, will not only let you into the secret but show you the difference between a "case-hardened," bit and one finished in the common way, which has this objection-a servant can never keep it to a polish, unless, like the soldier, he spends a long time in the process by using a pebble or his ramrod. Bits not case-hardened rust, even from the efrects of a foggy morning. They are, besides, soft, and, unless made very thick and clumsy, bend. With a case-hardened bit, supposing from neglect or any other circumstance it rusts, the rust will only be on the surface, and is got off readily. With the other it "eats in," and half a day is taken up in restoring it to the little polish it is capable of showing. The time of any man fit to be employed about a stable may be better occupied than in such an unthankful office. 


\section{MARTINGALS.}

These I consider as one of the most useful appendages we can use as regards the horse's carrying himself handsomely and pleasantly to the rider, when not disposed to do so. 'They are useful in two ways. With the good rider they bring and keep the horse's head in a proper place; and with a bad one, they prevent the badness of his hands pulling the head into an improper one. Of course, in the case of a good rider and a horse with a good mouth both together, the martingal is uncalled for.

The generality of persons form most e rroneous ideas as respects the effects of martingals : many 
stoutly affirm that they are dangerous, from confining the animal's head. It does this ; but, used properly, it merely confines it so far as to prevent the horse getting it into a position in which it never ought to be; and this restraint is under the influence of the rider's hand: relax the pressure on the bit, and the horse can place his head in any position and in any elevation he likes, or on an emergency may find necessary or convenient. It would be dangerous if the martingal was a fixed appui; but it is not. As applied to the reins only, these running freely through its rings (or, in preference, two little articles made for the purpose, very like a stirrup) relax all tendancy to confining the head, that is, if the hands, in technical terms, "give and take" with the motions of the horse.

Many persons would not, figuratively speaking, for worlds ride a horse at a fence with a martingal on. Now some horses, on seeing a fence before them, immediately throw up their heads. There can be no good result from the permitting such habit to be practised without control-it is, in fact 
objectionable. We want a horse to look at the fence he is about to take, and go steadily (however fast he may go) to it, not to rush "star gazing" at it, (which horses thus prone to elevate their heads are very apt to do). But, at all events, getting up the hand under such circumstances can do no good; therefore, thus far, it must be admitted that the martingal does at least no harm. On rising at his leap, or in going over, the rider will probably feel a certain slight pull at the reins, indicative of the horse wanting, or at least wishing for, greater liberty of head. What is the use of hands to a horseman, but to take such hint and indulge it when we conceive it necessary or convenient to the horse, and consistent with our own safety, that he should have it. Cavillers against martingals might say that the very pull I have represented against the hands is a sort of check to the horse, Not a bit: we are not to suppose a rider's hands and arms to be, like the blacksmith's, only sensible to the weight of a sledgehammer. The pull described might not check a child in any act he was performing, much less a 
horse when only held by a snaffle, or bridoon, which is pretty much the same thing; and to one of these the martingal is, in ninety-nine cases in a hundred, applied. In going over his leap, no exrtaordinary elevation of the head is necessary; and on landing we would wish a horse to look at the earth not at the skies.

There can be no doubt but, under certain circum stances, it may be necessary that a horse should have the liberty of raising his head to an unusual lieight-getting into a bog, for instance, or in his efforts to recover himself from a serious stumble at a leap or from putting his foot in a water drain or cart-rut. The martingal permits any sudden occasion for this, if the man's hands will permit it also ; it in fact allows a horse to do anything that he ought to do, it is only a check to prevent his doing the reverse.

Now for the martingal as regards road-riding, Carrying the head too high very much militates against the safety of the horse's going-not from the idea of his not seeing any obstacles in his way, 
but that by such carriage we lose all command over his mouth. His head once beyond a certain elevation, is, as would be the pole of a carriage without the pole-pin. We can no more control the action of the horse's body by the hand in such position than we can the impetus of the carriage with a pole so circumstanced. It is by the hold we have of his head, and urging him forward at the same time, we produce that grand desideratum "action;" relax our hold, he relaxes his action, unless naturally good or grand, as the case may be; but even then we gire it a stimulus by the same means as we improve bad or middling action, by holding the horse and at the same time exciting him-as he cannot increase his pace beyond what we wish him to do, the excitement causes him to do something, so he lifts his legs higher than he would do if left to himself. This is technically termed action. We only can keep this necessary hold of his head, or rather hold on the mouth, while it is in such position as enables us to keep the bearing on the right place. 
Elevating the head and elevating the body are two distinct things, and high action with the legs is a third; the head may be elevated to a preposterous height, yet the animal go displacing every pebble he comes in contact with on the road, which he very likely would do from our losing command of his mouth. Again, a horse may have high action as regards his legs, and yet no elevation of the body. This does not signify; in fact for a riding horse it is better tlian otherwise. The throwing up the body as well as the legs, looks handsome in the harnesshorse; but it is not desirable in the hack: he goes as safely without doing so as if he did, provided his "knee action" is what we could wish, and goes, easier to the rider than he would in the other case do. There can be no earthly objection to a martingal for road-riding, if the man's hands or the horse's habits render one desirable.

We now come to the nose martingal, an abomina. tion a good deal patronised by some London riders. It consists of a single fixed rim, running from the girths to a headstall and noseband, that is, a strap 
encompassing the nose. Many persons put on this (generally) unnecessary appendage, I firmly believe, merely from thinking it ornamental. It has two radical objections; if put on tight enough to keep the head in proper position, its being a fixture, renders it dangerous, as having no liberty for an occasional elevation of the head; and if put on so loosely as to admit of this, it is useless. If people put it on with the idea of checking a horse who has the umpleasant habit of tossing up his head, they make a great mistake. It may, and does, prevent his tossing it high enough to give you a blow on the face if leaning forward; but it rather increases the habit: the horse finds a check when he throws up his head; this he does not like; so as he can do it with impunity, he is constantly tossing up his head to find whether the obstacle is still there or removed.

Bad hands first teach horses to throw up their heads, and it is hard upon the animal to be punished for what he has virtually been taught to do; still in some cases the end will justify the means. If he 
tosses up his head so violently or pertinaciously as to become unbearable, ride'him a few times in a "rearing bit." This is an almost circular bit put into the mouth, and resting on the bars; it has a strap which is fastened to the girths, giving him ample liberty for the free use of his head, but when he tosses it up, this bit as it were gives him a blow on the bars of the mouth, and finding this invariably follows the act, he will leave it off. But in justice and mercy, when thus correcting a failing, allow not bad hands to give him not_merely an excuse but an actual hint to commit it.

If any one reading this article does not know what a rearing-bit is, most trainers and all bitmakers can show him one. If wanting a succedaneum for present use, a second snaffle-bit in the horse's mouth with the reins fastened to the girths, will do as a makeshift. This has the effect of punishing the mouth each time the head is thrown up; but it is, as I say, only a makeshift, is unsightly-and when a neat bit for the purpose is to be had for a sovereign, why not get it? 


\section{BUCK-JUMPING HORSES.}

IN compliance with the wishes of X. Y. Z. I will afford such information as I am master of on the subject of his communication. He particularly alludes to Buck-jumpers. There are others who I doubt not are more competent to treat on this subject than I am; for, though I have possessed horses with nearly every peculiarity of habit incident to the horse I never owned an animal addicted to the one in question, nor would I ride a horse who was so. I have certainly at times felt the peculiar sensation a buckjumping horse occasions his rider. This has been when I have imprudently at a slow pace suddenly 
turned a horse's head towards a moderate fence without giving him time to collect himself to take it properly. I have certainly, on such very few occasions, found him spring or bound over from the flexibility of his pasterns and hocks, as a man does from the pliability of his insteps and knees; but I do not recognise having ever felt a horse do this where he had time given him to prepare himself for his leap.

I saw some time ago a steeple-chase horse sold at Tattersall's, called "Buck-jumper:" whether so named from his being 'addicted to this style of fencing or not I am not aware; but if he was, I should say it was a very bad fault in a horse that cannot be allowed to lose time at his leaps, which I conceive horses leaping in such form must do both in taking off and landing. A horse cannot buckjump at speed; he must make a kind of stop to spring from all-fours at once, and on landing he is quite thrown out of his stride and has to collect himself ere he can get into it again. Suppose in taking off and landing he lost a second by this way 
of taking his fences, and there were thirty to be taken in the course marked out, he actually loses half a minute in the race-quite time enough to beat him.

X. Y.Z. says, "For instance the peculiarities of buck-jumping, which, I believe, Irish horses almost invariably do." Here, with submission, I consider him quite in error. I have had, when in Ireland for some years, opportunity of seeing, owning, and consequently riding, Irish horses, both in walled and bank and ditch countries; have seen many steeplechases there, seen trial leaps and wager leaps; but I cannot say I observed Irish horses in a general way more prone to buck-jumping than others.

Buck-jumping, of course, owes the origin of the term to the bounds we sometimes see fallow-deer make in passing us. I say fallow deer for this reason: during several seasons $I$ at one time hunted with the Queen's hounds, I never saw a red-deer attempt such feat. In leaping-and I have seen some hundreds of leaps taken by them-I always remarked the red-deer to jump precisely as the 
horse does. I have seen them take a leap at a "dead stand" and also at speed, in both which cases I hold my remark to stand good; and whether it was the Ripley or Hendon deer, or Lottery, the steeple-chase horse, their style of jumping was similar. The only quadruped $\mathrm{I}$ ever observed prone to buck-jumping has been the greyhound; they frequently bring their hind legs quite under their bodies, and from them, and their fore ones brought forward, throw themselves as it were by a bound over a fence. This I consider the height of buck-jumping, and this, to anything like the same extent, I never saw a horse attempt.

I consider that the little mistake made by X. Y. Z. as to Irish horses jumping in this manner arises from their bringing their haunches under them in leaping at an earlier period of the jump than in a general way do our English horses, who usually extend themselves more in taking a leap. By the time an Irish horse's rump is perpendicularly over the wall or fence his hind legs will be seen gathered up and over it too. The English horse at this pre- 
cise moment will be often found to have them, as in his gallop, stretched out behind him. He to a certain degree gallops over his fences, only raising his body and limbs high enough to clear the obstacle. $\mathrm{He}$, to speak figuratively, glides over his fences as we could imagine an eel would do over an obstacle six inches in height. This makes the English horse easier to sit on when fencing than the Irish horse -at least, with a few exceptions, I have found them so.

Another thing that may lead to the supposition of Irish horses being buck-jumpers is this-they mostly give themselves an additional impetus forwards by striking the wall or bank, or in fact anything that affords a point d'appui to the hind leg. The doing this, and finding the advantage of so doing, is the reason that Irish horses bring (as I have said) their hind legs under them quicker than English ones. An English horse, unaccustomed to walls, jumps them as he does gates; the Irish horse, at times, absolutely "dogs them"- - that is, in a momentary way, he places his fore-feet on the wall, like a dog, 
but it is done so quickly the eye can hardly detect the act.

Englishmen are at first a little astonished (I must not say alarmed) at finding Irish horses rattle the top stones of a wall about in jumping them. They will do so often with the fore-feet as well as the hind ones; they know from habit as well as the rider does that the stones, being put without cement or mortar, will give way, and, verily, they do sometimes knock them about rarely; but ride an Irish horse at a cemented brick or stone wall, he will be found very careful how he hits them with his fore-legs, though he will be sure to do so with his hind-feet, or rather shoes, for in this case he hits the wall in going over on the far side, and by this gains the impetus I have mentioned.

A horse can easily clear a gate of from four feet three to four feet seven in his stroke; not so walls, often from five feet to five feet many inches high.

Some sportsmen may think I underrate the height of gates. If he think so, I will engage to give him 
two sovereigns for every gate we may find (in a walk over a farm) more than four feet seven as it is hung, if he will engage to give me one for each field gate we find, on measurement, to be lower. Of course, I mean in counties where gates are of common height, and on farms where they are so, also. Let me observe that timber leaps always appear higher than they really are, the rails of the gate and the interstices producing a deceptive appearance as to the height. Independent of this, there is a noli me tangere look about a gate that with the boldest riders always causes them to eye such obstacles with closer scrutiny than they use at ordinary fences.

The want of surface in the top bar of a gate, on which the hind legs may get a momentary resting place, causes Irish horses to be shy of such leaps till accustomed to them; and I think it by no means improbable that coming to a description of impediment to which he is unused may have so puzzled and astonished an Irish horse that he momentarily hesitates and then bucks it, perhaps. Having seen this may have led our correspondent 
X. Y. Z. into the error of Irish horses being "in variably" buck-jumpers.

Let an Irish sportsman come to England for the first time and mount him on a Leicestershire hunter, without having given the rider a previous caution, he would throw the horse completely out of his stride, and, probably, into his leap, by using the almost invariable practice with Irish riders of lifting horses at their leaps; and, vice versâ, mount an English rider, under the same circumstances, on Irish horses, he will find he can make no hand of them at all, though in either case the rider may be as judicious and bold a horseman as ever bestrode a saddle, and each horse as perfect a hunter as ever gladdened the eye of a sportsman.

A friend of mine had a horse that he complained of as not being able to make leap, but on the contrary, would not raise himself at his fences. $\mathrm{He}$ added, as a more singular thing, that he had understood it was an Irish lhorse, who he had always heard were remarkable for their jumping attributes, I begged to see him perform. He put his groom on 
him, who resolutely enough rode him at a slightmade post and rail fence; true enough, the horse never rose half high enough to clear it, but carried with him the top rail. I begged to get on him; rode him at the same fence, gave him a direct haul up where he should take off, accompanied by an Irish shout : he cleared it at once, and, to quote the groom's description, "jumped high enough for to-day and tomorrow too."

What I did was necessary, under the circumstances, though I quite deprecate the system. 


\section{CLIP PING HORSS.}

THE process of clipping has long been so well understood that any description of it is quite unnecessary, and more so as, within the last few years, singeing has superseded it. The artificially shortening the coat was, I believe, first practised in Leicestershire, and that thirty-five years since, it gradually crept into general use, and cracked heels, inflamed lungs, swollen legs, and broken wind was the frequent result, people seeming to forget, or not to consider, that a process that was quite proper, extremely desirable, and a source of comfort to a hunter whose body was never exposed to the cold air without his body- 
clothes except when hunting, was, on the contrary, one that produced much suffering and danger to a horse subject to different treatment and different employ.

Clipping has now had its day, and singeing has very properly taken its place. It is quite evident that cutting of a hair that is a hollow tube must admit the access of air. What, then, must be the effect produced by thus admitting cold air to the body by millions of open orifices? Now, on the contrary, singeing, as it were, hermetically seals up these orifices as we go on; all the effect the animal feels from it is what a man experiences when taking off an upper coat. But be it borne in mind that, with all the advantage singeing has over the old practice of clipping, a horse closely singed must no more be exposed (when standing still) to draughts, wind, rain, or extreme cold, than must the man without his additional coat. When clipping was in vogue it was often pitiable to see horses standing shivering with cold in medical men's carriages, and in many other cases similarly exposed; even horses waiting for their mas- 
ters to mount them showed often as sad specimens of injudicious exposure to cold.

Before any man has a horse singed let him consider for what purpose he wants him, and how far he is likely to be exposed to the inclemency of the weather; having considered that, let him have his horse singed accordingly, for a further most important advantage singeing has over clipping is-in the latter process a horse, to look well, must be clipped quite close. In singeing this is not the case; it can be done so as to leave sufficient protection to the body, without any undue length of coat being taken off; in point of fact, a very long coat cannot be closely taken off at one operation; in the first place, it would be unevenly done if attempted, and secondly, passing the flame repeatedly over the same part produces an exudation from the pores of the skin that renders the coat clammy, and after this all effect from the apparatus ceases. After going evenly over the surface the horse should be well washed with soap and warm water, with a proper proportion of soda in it; this cleanses the coat and skin. If in a few days we wish 
the coat shorter, we must again go over it ; then it would be proper to give the horse a sweat if convenience can be found for doing so. By sweating I do not mean the partial sweating he sometimes gets in ordinary work, but sweating till he will scrape. The reason why I do not recommend such a sweat on a first singeing is, that with the portion of coat still left on him we might find the drying him thoroughly a long process, during which he very probably might take a severe cold; nothing so effectually cleanses the pores of the skin as a sweat and scraping: the soap and water, particularly with soda in it, perfectly cleanses the hair, but it does not do so as regards the skin. The repetition of the operation must of course depend on the state of the coat ; for some very thincoated horses once singeing may do, but not if they have either a long or thick one.

Clipping used to leave all bays, browns, chesnuts, and blacks, more or less of a very light mouse colour; singeing does not. We know that the coat of such horses is light-coloured as we approach the skin; so clipping naturally brought us to such hue. Now 
singeing, if desired, will reduce the coat to as short a length as clipping, yet no such direct change of colour is effected by it; we must therefore infer that we, in fact, char the hair as we go on, which accounts for it not showing the same hue as a clipped coat. Grey, dun, or roan horses, in point of appearance, look to the full as well after being clipped as singed. We have only the objection to their being, without great care, very liable to take cold after the operation; if, however, we have patience to wait until nature again closes the ends of the coat, which it will very soon do by its growth, no danger need be feared, unless the horse is exposed to such cold as no animal can be expected to endure with impunity having but a slight covering of hair on his body.

It will be found that, so soon as the horse's coat begins to shoot in the autumn, the groom will intercede with his master to have his horses clipped or singed, and will, moreover, give his directions to the man employed to get as much of the coat off as possible, forgetting, or probably not caring (provided he is saved trouble) that a coat that may be very proper 
for a hunter is by no means desirable for horses for common use ; nor is it necessary. If a horse, in point of health, constitution, and having been properly treated, is in proper condition-by this I mean such condition as fits him for the work required of himhe will not sweat much by the ordinary work required of London riding or harness horses. Now, a cover hack is in a different position; he is brought out, his master jumps on his back, and he has to go ten, twelve, sometimes for more miles, at all but a hunting pace. It is therefore clear he wants the condition of the hunter; and, as he is often as profusely sweated, the same coat is desirable for him. But the ridinghorse, who is only required to go from (say) Grosvenor-place to the Club-house in Pall-mall, and from thence to Hoby's, or Fortnum and Mason's, en passant to Hyde Park, wants neither the condition of the cover-hack nor his short coat-in fact, the latter, figuratively speaking, is death to him. Arrived at the Park, a walk up and down, and perhaps a canter of the length of the ride, will not call forth perspiration enough to be in any way troublesome with a fair 
share of coat left on his body. It is true at the time of year that horses are now ridden in the park their coat is naturally short; but, mutatis mutandis, the same difference holds good as regards the required condition and coat of horses used merely for what to them is exercise and others in strong work.

It may be very well for the coachman of a nobleman or man of fortune to have his horses singed close ; but it would be perfectly absurd for a medical man to permit his horses to submit to the same process; and the coachman of an old dowager, who keeps her horses shivering while she is shopping, or at night finishing a rubber at whist, would neither show his judgment or honesty in having his horses all but denuded: the fool or lazy fellow who would, should be made wait with his horses in his shirt only. If gentlemen will exercise their own discretion and judgment, or take that of others (and not the grooms), in seeing that the coat is only shortened in proportion to the work required of their horses, I recommend singeing them as a means by which their servant is saved useless trouble, the appearance of the animal much improved, 
and he will perform his work with comfort both to himself and owner.

Stud-grooms can, of course, singe the horses themselves. Men not in positions to keep such servants may probably be able to do the same thing by their own hand; but persons having such grooms as usually fall to the lot of those keeping a couple of horses had far better employ men used to the business, who, for a moderate gratuity, will singe their horses properly, and, with proper directions judiciously. 


\section{HORSES KICKING IN HARNESS.}

I Alr tempted to take up my pell on this subject from seeing yesterday one of, I think, the merriest kickers I ever saw in harness of any sort; he was in a cab, not a Hansom's, not one of the Slow-andeasies, or uneasy as the case may be. "Merry!" I think I hear the old lady say, who very wisely made her exit from the cab, and sought shelter in a shop, thinking, I conclude, that the horse had some animosity personally to herself, and would follow her if she remained visible. In spite of the old lady, I repeat the word merry, for at one time I had a good deal to do with such gentlemen. 
Some from sheer vice; some from commencing in wantoness, but ending in earnest; others from neither the one or the other, but from alarm, or having been alarmed, which nine times in ten is the origin of horses kicking in harness; hence the difficulty, I may say almost impossibility, of ever curing a horse of the habit so as to be able to depend on him. The horse I allude to when I came up had got on to the pavement, and was rattling the old machine about rarely, as if in revenge for the many weary miles he had probably at times travelled before it. The driver, who looked out of his place when not driving a mourning-coach, was trying to get the horse disengaged from the cab; while a man, who seemed to know something of what he was about, had caught the horse by the ear, trying to convert his hands into a twitch. This often succeeds; but in this case it did not-the horse, in technical phrase, kept "milling away a good un." My former habit of dealing with such reprobates, and a little presence of mind, served me, or at least it served the owner 
of the cab. I made my way through a crowd of all sorts of persons but the right sort, got up to the horse, and, giving him two or three sharp strokes under the back part of the knee with my stick, caused him to lift his fore-leg, which I caught, and held tight till I got one of the reins and tied the leg fast doubled up; of course this stopped his kicking; he struggled, and finding himself hampered, squealed like a pig, but he could not kick without throwing himself down. Having done so far, I left Cabby, who seemed too much frightened to thank me. He had not had as many Irish kickers in harness to deal with as I have. They can kick.

Horses are not naturally vicious animals; and when they rebel against our wishes, nine times in ten it proceeds from having been previously frightened, being at the time alarmed, not understanding what we want tham to do, or their spirit or rage being roused by ill-usage. I allude to English; Irish horses are by no means so amenable, particularly as regards harness; they appear 
to have a particular dislike to it at first, and generally attempt some devilry or other when first put in. But, as regards English horses, be but gentle with them, and use proper caution on first trying them in harness, and not one in ten will attempt mischief. Many a horse is rendered unsafe (that is, not to be trusted) in harness by those unaccustomed to such business attempting to put them in harness themselves. They may, perhaps, save the charge of breaking to harness by getting a cart and putting their horse in it; sometimes they succeed, but, even if they do, they have probably, without knowing it, given the horse cause of alarm, or distaste to harness, which be never forgets, and will, some time or other, give them a proof of it. If they do not succeed, they have, by the attempt, brought the horse to a state of fright, anger, or resistance that possibly the most experienced and efficient breaksmen cannot eradicate.

The uninitiated are not aware of the very slight mistakes that will cause a horse to kick on being first put into harness. The mere putting the 
crupper on, if done suddenly, in putting on the harness, will sometimes cause him to kick. Probably, with the harness loose on his back, his kicking on first feeling the crupper sends it off him, or partly so. The horse gets seriously alarmed at this; a scene ensues; and then there is (to use the designation of a farce) "the devil to pay."

Backing a horse into the shafts (which should never be done) is very likely to set him kicking.

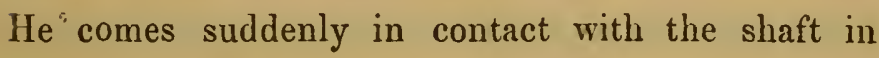
some part, and either he rushes forward in alarm, or sends his heels at it. This night be termed lesson the first in virtually teaching the animal to kick.

If in double harness, the very turning a corner incautiously will cause many a horse to kick, from feeling the pole or trace suddenly come in contact with his thigh.

Even throwing the driving rein to be buckled over the young horse's back, instead of that of the break horse, which a stupid or careless fellow 
might do, will probably alarm a horse new to harness. He rushes forward, is checked by the traces, then backs himself suddenly, is then checked by the pole-piece and collar, feels himself hampered in every way, gets alarmed or angry. Here, probably, is "the devil to pay" again.

It will be found that brute force or brutal violence rarely succeeds or produces the desired effect with horses, or, indeed, with any animal. Brute force subdued Van Amburg's lions, but it did not tame them. They were too much subdued to attack him while his eye was on them, but if he had turned his back they would have pulled him down, and torn him to pieces. Brute force may compel a horse to do a particular act at the time-it may even make him fear to commit one at variance with our safety; but let opportunity occur, we should soon find that fear alone will never eradicate a bad propensity.

I remember in something I have written to have warned persons from purchasing a horse that has 
hicked, on the assurance that he had been cured of the habit. I give the same advice now; but let me be understood. I by no means say that because a young horse may have kicked on being first put in harness he is for ever to be rejected. Using his heels is the natural act of the horse in many cases when displeased, as using his fists is that of the man. The novelty of being confined in harness may cause a young horse to kick; but when used to the restraint, he may not, and probably will not, ever feel inclined to do so again. But if a horse, when once used to harness, kicks, depend on it he will kick again on the slightest cause given. The horse I mention in the beginning of this article as kicking in the cab, no power or means on earth could cure of the vice. $\mathrm{He}$ might be driven, and in single harness, with a good kicking-strap properly put on, might be driven as well as any other horse; but kick he ever would if he had a chance.

Many horses that have kicked will frequently go quiet enough, provided the same thing does not 
occur as that which first caused them to kick, which may have been a very simple affair after all. For instance :

I had a niare that had always gove quietly in harness. One day a man came galloping past me; the mare being very fresh, and in high condition, squeaked and threw up her heels in mere wantonness; but finding the cross bar of the gig oppose her, she "set to" in earnest, and the combined efforts of myself and man could only hold her, while a third person disengaged her from the vehicle. The next day I put her again in harness, but with an unmistakeable kicking-strap on. She went perfectly quiet, and continued to do so, till one day a person passed us as before; she remembered the kicking-match, and, but for the kicking-strap, would have, in technical phrase, "kicked a town down." I drove her for six months after this, she being a favourite and wager-fast. I then was tempted by price and sold her, telling the purchaser of her propensity.

I have now given such hints as space permits as 
HORSES KICKING IN HARNESS.

regards kickers, and the many causes of kicking. In a future article I may, perhaps, attempt to show how to order things better than they are sometimes done in putting horses in harness.

THE END. 


\section{N D E X.}

A fair Beginning

PAGE.

Boxes for Horses

110

Bridles

206

Buck-jumping Horses.

225

Clipping Horses

242

Concerning the Stud

251

Errors as regard the Stud

152

Experientia docet (sometimes)

171

Hints to Young Sportsmen and others

Horses Cutting

Horses Kicking in Harness

190

Martingals

261

Purchasing Horses

234

Purchasing Horses and its consequences

Purchasing Horses the Right Way .....

Riding

38

Seeking a Stud

215

Tattersall's and other places

130

What is a good sort?

64

93 


